(2) norden 



\section{Hexabromocyclododecane as a possible global POP}




\section{Hexabromocyclododecane as a possible global POP}

TemaNord 2008:520

(C) Nordic Council of Ministers, Copenhagen 2007

ISBN 978-92-893-1665-1

Print: Ekspressen Tryk \& Kopicenter

Printed on environmentally friendly paper

This publication can be ordered on www.norden.org/order. Other Nordic publications are available at www.norden.org/publications

Printed in Denmark

\section{Nordic Council of Ministers}

Store Strandstræde 18

DK-1255 Copenhagen K

Phone (+45) 33960200

Fax (+45) 33960202

www.norden.org

\section{Nordic Council}

Store Strandstræde 18

DK-1255 Copenhagen K

Phone (+45) 33960400

Fax (+45) 33111870

\section{Nordic co-operation}

Nordic cooperation is one of the world's most extensive forms of regional collaboration, involving Denmark, Finland, Iceland, Norway, Sweden, and three autonomous areas: the Faroe Islands, Greenland, and Åland.

Nordic cooperation has firm traditions in politics, the economy, and culture. It plays an important rol in European and international collaboration, and aims at creating a strong Nordic community in a strong Europe.

Nordic cooperation seeks to safeguard Nordic and regional interests and principles in the global community. Common Nordic values help the region solidify its position as one of the world's most innovative and competitive. 


\section{Content}

Preface.

Summary

1 Introduction

2. Chemical identity

3. Physical and chemical properties.

4 Information on hexabromocyclododecane in relation to the POP screening criteria.

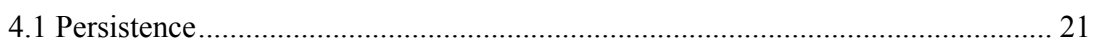

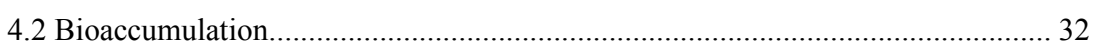

4.3 Potential for long-range environmental transport .................................................... 38

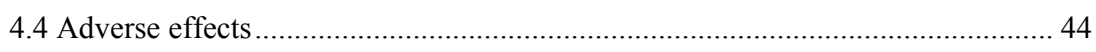

5. Statement of the reasons for concern and need for global action................................... 49

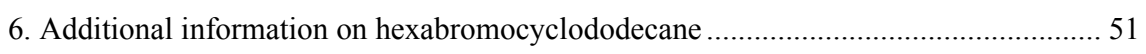

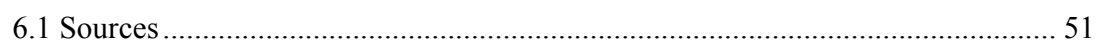

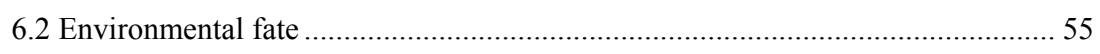

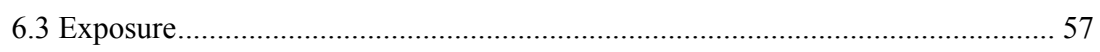

6.4 National and international administrative actions on

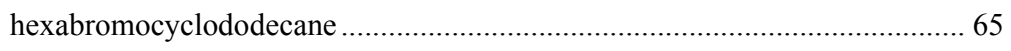

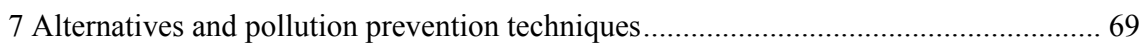

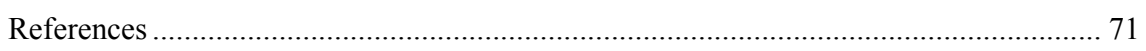

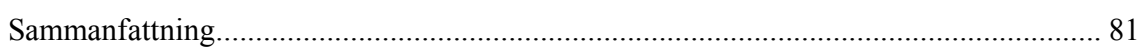

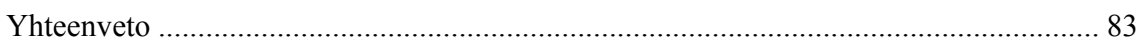

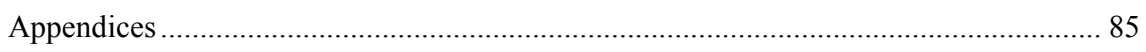

Appendix 1 Annex D of the Stockholm Convention ................................................... 85

Appendix 2 Executive body decision 1998/2 on information to be submitted and the procedure for adding substances to Annexes II or III to the POPs Protocol (EB.AIR/WG.5/52, ANNEX II).

Information to be submitted and the procedure for adding substances to annexes $\mathrm{i}$, ii or iii to the protocol on persistent organic pollutants.

Appendix 3 Properties of 1,5,9-cyclododecatriene (CAS 4904-61-4) ......................... 89

Appendix 4 The results of the EU risk assessment, quantitative risk characterisation for the environmental part

(European Commission, 2007a) 


\section{Preface}

This report has been prepared by Johanna Peltola-Thies (consultant) under a contract with the Nordic Chemicals Group. The work has been financed by the Nordic Council of Ministers. Bjørg Fjeld from Statens forurensningstilsyn, Norway, has been in charge of the project. She and other members of the project group, Anette Albjerg Ejerstedt (Miljøstyrelsen, Denmark), Lars Andersson (Kemi, Sweden), Gunnlaug Einarsdottir (Umhverfisstofnun, Iceland), Timo Seppälä (Suomen ympäristökeskus, Finland) and Liselott Säll (Statens forurensningstilsyn, Norway) have provided valuable information and guided the work with their comments. The author would like to thank the project group members for their input. 


\section{Summary}

The objective of this report is to review the relevant information on a brominated flame retardant hexabromocyclododecane (HBCDD) in relation to the screening criteria of the Stockholm Convention on Persistent Organic Pollutants (POPs) and of the Protocol on Persistent Organic Pollutants of the UNECE Convention on Long-Range Transboundary Air Pollution for adding new substances to these instruments. Some additional information needed in the consideration of the possible nomination of the substance as a new POP is also provided.

According to the available data, HBCDD fulfils the POP screening criteria of both POP frameworks.

HBCDD fulfils the numerical POP criteria for half-life in air. Modelling results and measured data from remote areas show that HBCDD can be transported long-range in the environment.

Based on the available data, HBCDD meets the POP persistency criterion for soil. The available degradation simulation studies for sediment indicate that the substance can be persistent enough in aerobic sediment depending on the temperature, and the environmental data from sediment indicate, that the actual sediment half-lives of HBCDD in the environment can be longer than what would be expected based on the experimental half-lives.

The bioconcentration of HBCDD in fathead minnow and rainbow trout was found to be very high, well above the POP screening criterion. Field concentrations in aquatic biota have been shown to increase as the trophic level increases, which means that HBCDD biomagnifies in the aquatic food web. Several studies on top predator bird species give further evidence of bioaccumulation and persistency against biological transformation in the food web.

Based on HBCDD's high aquatic ecotoxicity, it is concluded, that HBCDD clearly fulfils the toxicity screening criteria set for POPs. The various adverse effects observed in laboratory in mammals provide an additional concern. The main effects detected in laboratory mammals are disturbances in liver and thyroid gland including thyroid hormonal changes. Developmental neurotoxicity and impacts on sexual organs have also been observed in laboratory mammals, but those effects should be subject to further investigations before final judgment on their relevance can be made.

There are also other reasons for concern. HBCDD has been found in very high concentrations in the blubber of marine mammals in a large amount of samples from different regions. An increasing temporal trend has been observed in some marine bird populations in the Arctic. Recent 
studies from two continents have found HBCDD in breast milk and human blood. According to the available data, HBCDD is transferred from mother to child via cord blood during pregnancy and through breastfeeding after delivery.

HBCDD is used mainly in expanded and extruded polystyrene. Most of this HBCDD treated polystyrene is used for insulation boards for, e.g., buildings and vehicles. Other applications are the use in textile coatings and in high impact polystyrene for electrical and electronic equipment. Global market demand for HBCDD was $16700 \mathrm{t}$ in 2001, whereas the largest part of the tonnage was used in Europe.

The major part of those European releases, which were quantifiable during the last years, enters to the environment from point sources. Nevertheless, also diffuse sources may be relevant contributors to the environmental exposure. The volume of HBCDD increases in the built technosphere (articles in use) constantly. Diffuse releases from materials during service life and during waste management steps occur, but they could not be fully quantified so far. Based on monitoring data, HBCDD is contained in wastewater collected by such municipal sewage treatment plants, which have no known industrial HBCDD users connected. Alternative chemicals and techniques for avoiding the use of HBCDD are available for most of its uses. European industry has already started voluntary programs to manage the releases from industrial sites. 


\section{Introduction}

Hexabromocyclododecane (HBCDD) is the third most used brominated flame retardant globally, whereas the main share of the market volume is used in Europe. Although HBCDD has not yet been studied by the scientists to the same extent as polybrominated diphenylethers (a group of brominated flame retardants consumed in a larger global volume than HBCDD), the knowledge of the substance properties and of its abundance in the environment has increased during the last decade to such an extent, that some alarming consequences of the production and use have become visible. As a result, the substance was under the Existing Substances Regulation (93/793/EEC) of the European Union already concluded to be of very high concern due to its persistent, bioaccumulative and toxic (PBT-)properties. PBT-substances are foreseen in Europe to be subject to minimisation of emissions.

At present, two international instruments manage the risks arising from persistent organic pollutants (POPs). These are the global Stockholm Convention on Persistent Organic Pollutants (adopted in 2001; further referred as "Stockholm Convention") and the Protocol on Persistent Organic Pollutants of the UNECE Convention on Long-Range Transboundary Air Pollution (adopted in 1998, entered into force in 2003; further referred as "UNECE POP Protocol"). Both frameworks regulate, i.a., the production, use and waste management of selected POPs.

Both instruments have mechanisms and screening criteria for including new substances within their scope. The screening criteria are approximately the same in both instruments. Firstly, the substance has to have potential for long-range environmental transport (LRET). In addition, there has to be evidence that the substance is persistent in the environment and that it is bioaccumulating. Also evidence of its ability to cause adverse effects is required. The full criteria are included in Appendices 1 and 2 and an aggregated form is presented in in the box below.

This document reviews the key information on the properties of commercially available hexabromocyclododecane in relation to the POP screening criteria and provides some additional information needed in the consideration of its possible nomination as a new POP. The report is structured mainly to serve the requirements of the Stockholm Convention. Chapters 2, 4 and 5 present the information listed in Annex D, paragraphs 1 and 2 of the Stockholm Convention required for the screening phase of a proposal. In addition, physical-chemical properties (chapter 3) have been presented at the beginning of the report to facilitate the understanding of the following chapters. Chapters 3, 6 and 7 contain additional information, as stipulated in Annex E of the Stockholm Convention. 
The review relies mainly on the European Union risk assessment of hexabromocyclododecane (European Commission, 2007a), which has been conducted under the Existing Substances Regulation 93/793/EEC. For the risk assessment, all available data have been evaluated in detail by the Rapporteur Sweden and the evaluations have been checked and agreed among experts representing the European Union Member States and Norway. The risk assessment and "Strategy for limiting risks, hexabromocyclododecane (Swedisch Chemicals Agency, 2007)", which was developed as a consequence of the conclusions of the risk assessment, contain also a considerable amount of additional information. Some new estimates have been derived for this report and the latest relevant monitoring data have been added. It is noted, that the amount of data from especially studies exploring HBCDD abundance in the environment and on the fate of different diastereomers is steadily increasing. 


\section{The POP screening criteria in brief}

\section{Long-range environmental transport (LRET)}

The Stockholm Convention requires, that there are: (i) measured levels of the chemical in locations distant from the sources of its release that are of potential concern or (ii) monitoring data showing that long-range environmental transport of the chemical, with the potential for transfer to a receiving environment, may have occurred via air, water or migratory species; or (iii) environmental fate properties and/or model results that demonstrate that the chemical has a potential for long-range environmental transport through air, water or migratory species, with the potential for transfer to a receiving environment in locations distant from the sources of its release. For a chemical that migrates significantly through the air, its half-life in air should be greater than two days.

The UNECE POP Protocol requires, that the substance should have a vapour pressure below 1,000 $\mathrm{Pa}$ and an atmospheric half-life greater than two days or, alternatively, monitoring data are available showing that the substance is found in remote regions.

\section{Persistence}

Both criteria require the substance to have a half-life of greater than two months in water or that half-life in soil or sediment is greater than six months or that the substance is otherwise sufficiently persistent to be of concern.

\section{Bioaccumulation}

Both criteria require, that the substance has a $\mathrm{BAF}$ or $\mathrm{BCF}>5000$ or a logKow $>5$ or, alternatively, if these criteria are not met, there are other factors, such as the high toxicity or ecotoxicity of the substance, that make it of concern, or monitoring data in biota indicate that the bioaccumulation potential of the chemical is sufficient to justify its consideration.

\section{Toxicity}

Both instruments require, that there is information/evidence on the potential of the substance to cause adverse effects either to human health or to the environment. 


\section{Chemical identity}

Commercially available hexabromocyclododecane (HBCDD) is a white solid substance. Producers and importers have provided information under the European Union statutory requirements under two names (see below) and corresponding CAS and EINECS numbers. Both of these substances are covered by this report. There are no known differences in molecular structure or properties of these two substances. According to the producers, the structural formula below represents the substance as it is on the market.

IUPAC name:

EINECS name:

CAS No.:

EINECS No:

EINECS name:

CAS No.:

EINECS No.:

Molecular formula:

Structural formula:<smiles>BrC1CCC(Br)C(Br)CCC(Br)C(Br)CCC1Br</smiles>

Molecular weight:
Hexabromocyclododecane

Hexabromocyclododecane

25637-99-4

247-148-4

1,2,5,6,9,10-Hexabromocyclododecane

3194-55-6

221-695-9

$\mathrm{C}_{12} \mathrm{H}_{18} \mathrm{Br}_{6}$

Synonyms (including trade names): Cyclododecane, hexabromo; HBCD; Bromkal 73-6CD; Nikkafainon CG 1; Pyroguard F 800; Pyroguard SR 103; Pyroguard SR 103A; Pyrovatex 3887; Great Lakes CD-75PTM; Great Lakes CD-75; Great Lakes CD75XF; Great Lakes CD75PC (compacted); Dead Sea Bromine Group Ground FR 1206 I-LM; Dead Sea Bromine Group Standard FR 1206 I-LM; Dead Sea Bromine Group Compacted FR 1206 I-CM;

According to the producers, HBCDD is manufactured by bromination of the starting material cis,trans,trans-1,5,9-cyclododecatriene. Technical 
grade HBCDD consists depending on the producer of approximately 70$95 \% \gamma$-HBCDD and 3-30\% of $\alpha$ - and $\beta$-HBCDD (see Figure 2.1) due to its production method (European Commission, 2007a). Based on the analyses of Heeb et al. (2005), these chiral diastereomers are present in the technical product as enantiomer pairs, where the ratio of enantiomers is assumed to be ca. 1:1. Two other stereoisomers, $\delta$-HBCDD and $\varepsilon^{-}$ HBCDD have also been found by Heeb et al. (2005) in commercial HBCDD in concentration of $0.5 \%$ and $0.3 \%$, respectively. These impurities are regarded as achiral at present. According to the same authors, $1,2,5,6,9,10$-HBCDD has six stereogenic centers and therefore, in theory, 16 stereoisomers could be formed.

Albemarle Corporation (2005) has reported that their commercial product consists of 80-85 \% $\gamma$-HBCDD, 8-9 $\% \alpha$-HBCDD and $6 \% \beta-$ HBCDD. According to Albemarle, the majority of the global market consists of HBCDD products containing $80-85 \% \gamma$-HBCDD, whereas only one manufacturer would produce a HBCDD -product containing ca. 90 $\% \gamma$-HBCDD.
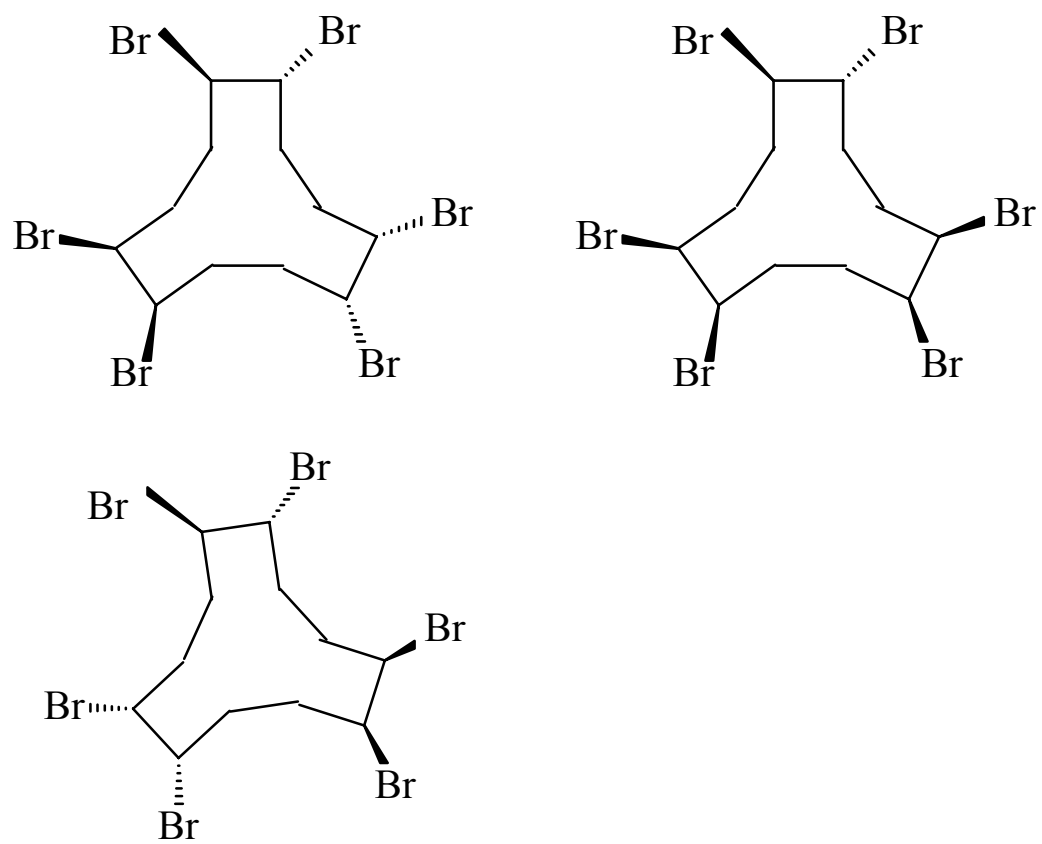

Figure 2.1 The constituents of commercial HBCDD. From left to right: CAS No. 13423750-6: $\alpha-H B C D D$; CAS No. 134237-51-7: $\beta$-HBCDD; CAS No. 134237-52-8: $\gamma$-HBCDD

More detailed information on the stereochemistry of HBCDD is presented in the European Commission (2007a) and references therein. According to European Commission (2007a), three companies operating on the European market place HBCDD on the market in seven products in total. Only one product of these contains a rather low concentration (40$60 \%$ ) of HBCDD, the other products are high-purity, heat stabilised 
grades. Impurities make in these products $<4 \%$ and they include tetrabromocyclododecene and other brominated cyclododecenes.

Albermarle Corporation (2005) reports a purity of $96-99,9 \% \mathrm{w} / \mathrm{w}$ for their product, a major impurity being tetrabromocyclododecene. According to the company, impurities typically observed on the U.S. market are tetrabromocyclododecene and isobutanol.

It is noted, that in most studies carried out before approximately the year $2000 \mathrm{GC} / \mathrm{MS}$ has been used for the analysis of HBCDD. This system is, however, due to thermal rearrangement of the diastereomers (see next chapter) not capable of distinguising the original diastereomeric distribution of HBCDD in samples, and analyses employing GC/MS can therefore reflect only the total concentration of all HBCDD diastereomers. Studies using liquid chromatography have become a more common practice within the last years. With LC or HPLC elution the different diastereomers and enantiomers can be quantified (see European Commission, 2007a). 


\section{Physical and chemical properties}

Data on physical-chemical properties of HBCDD have been evaluated and described in detail in the EU risk assessment (European Commission, 2007a). The summary of the properties is presented in Table 3.1

Table 3.1 Summary of physical-chemical properties (European Commission, 2007a)

\begin{tabular}{|c|c|c|}
\hline Property & Value & Reference \\
\hline Chemical formula & $\mathrm{C}_{12} \mathrm{H}_{18} \mathrm{Br}_{6}$ & \\
\hline Molecular weight & 641.7 & \\
\hline Physical state & White odourless solid & \\
\hline \multirow[t]{2}{*}{ Melting point } & Ranges from approximately: & Smith et al. (2005) \\
\hline & $\begin{array}{l}172-184^{\circ} \mathrm{C} \text { to } 201-205^{\circ} \mathrm{C} \\
190{ }^{\circ} \mathrm{C} \text {, as an average value, was used as input } \\
\text { data in the EU risk assessment model EUSES. } \\
179-181^{\circ} \mathrm{C} \quad \alpha-H B C D D \\
170-172{ }^{\circ} \mathrm{C} \quad \beta-H B C D D \\
207-209^{\circ} \mathrm{C} \quad \mathrm{Y}-\mathrm{HBCDD}\end{array}$ & \\
\hline Boiling point & Decomposes at $>190^{\circ} \mathrm{C}$ (see also text below) & Peled et al. (1995) \\
\hline \multirow[t]{2}{*}{ Density } & $2.38 \mathrm{~g} / \mathrm{cm}^{3}$ & $\begin{array}{l}\text { Albemarle Corporation } \\
\text { (1994) }\end{array}$ \\
\hline & $2.24 \mathrm{~g} / \mathrm{cm}^{3}$ & $\begin{array}{l}\text { Great Lakes Chemical } \\
\text { Corporation (1994) }\end{array}$ \\
\hline Vapour pressure & $6.3 \cdot 10^{-5} \mathrm{~Pa}\left(21^{\circ} \mathrm{C}\right)$ & Stenzel and Nixon (1997) \\
\hline Water solubility $\left(20^{\circ} \mathrm{C}\right)$ & see Table 3.2 & \\
\hline $\begin{array}{l}\text { Partition coefficient } n \text { - } \\
\text { octanlol/water }\end{array}$ & $\begin{array}{l}\text { Log Kow }=5.62 \text { (technical product) } \\
5.07 \pm 0.09 \alpha-\mathrm{HBCDD} \\
5.12 \pm 0.09, \beta-\mathrm{HBCDD} \\
5.47 \pm 0.10 \gamma-\mathrm{HBCDD}\end{array}$ & $\begin{array}{l}\text { MacGregor and Nixon } \\
\text { (1997) Hayward et al. } \\
\text { (2006) }\end{array}$ \\
\hline Henry's Law constant & $\begin{array}{l}0.75 \mathrm{~Pa} \times \mathrm{m}^{3} / \mathrm{mol} \\
\text { Calculated from the vapour pressure and the } \\
\text { water solubility }(66 \mu \mathrm{g} / \mathrm{l})\end{array}$ & \\
\hline Flash point & Not applicable & \\
\hline Auto flammability & Decomposes at $>190{ }^{\circ} \mathrm{C}$ & \\
\hline Flammability & Not applicable-flame retardant! & \\
\hline Explosive properties & Not applicable & \\
\hline Oxidizing properties & Not applicable & \\
\hline Conversion factor & $\begin{array}{l}1 \mathrm{ppm}=26.6 \mathrm{mg} / \mathrm{m}^{3} \\
1 \mathrm{mg} / \mathrm{m}^{3}=0.037 \mathrm{ppm}\end{array}$ & \\
\hline
\end{tabular}

Peled et al. (1995) observed, that thermal decomposition at $170-190{ }^{\circ} \mathrm{C}$ was slower for $\alpha$ - and $\beta$-HBCDD than for $\gamma$-HBCDD. At $190{ }^{\circ} \mathrm{C} \alpha$ HBCDD decomposed most slowy and at $200{ }^{\circ} \mathrm{C} \beta$ - and $\gamma$-HBCDD were more resistant to decomposition than $\alpha$-HBCDD. The authors saw also thermal rearrangement to occur when heating individual diastereomer 
samples. At $190{ }^{\circ} \mathrm{C}$, each of the three diastereomers rearranged within 30-60 minutes to give a composition of approximately $78 \% \alpha$-HBCDD, $13 \% \beta$-HBCDD and $9 \% \gamma$-HBCDD. It is noted, that both of these phenomena can be expected to have influence to the diastereomeric fingerprint of HBCDD in releases and in products originating from processes where high temperatures are used. For example, although in the Scheldt basin (the North Sea) sediments $\gamma$-HBCD was found to be the predominant diastereomer, in some of its areas, e.g. at Oudenaarde and St. Martens which are close to textile industry, high total HBCDD concentrations were connected with elevated levels of the $\alpha$ - diastereomer (de Boer et al., 2002).

Water solubility results derived with generator column method are presented in Table 3.2. This is a method, which can measure water solubilities of specific diastereomers present in the commercial HBCDD. In order to reach the maximum solubility of each diastereomer, it was due to the low proportion of $\alpha$-HBCDD and $\beta$-HBCDD in the commercial grades necessary to add a higher amount of test substance into the test system than the sum of water solubilities of all stereoisomers. It is not possible to estimate based on the results, how much the presence of three diastereomers influences the water solubility of each of them.

The apparent water solubility of commercial HBCDD is close to the water solubility of $\gamma$-HBCDD, because it is present in the commercial HBCDD at the highest concentration and due to its low water solubility starts to precipitate first. It is considered, that the environmentally relevant water solubility is the sum of the solubilities of all three diastereomers $\left(0.066 \mathrm{mg} / 1\right.$ at $\left.20^{\circ} \mathrm{C}\right)$. By using this water solubility, the expection is reflected, that the true water solubilities of all three diastereomers can be reached in realistic exposure conditions independent on the diastereomeric fingerprint of the product or of the emissions.

Table 3.2 Summary of the results of valid water solubility studies using generator column method, as evaluated by European Commission (2007a).

\begin{tabular}{|c|c|c|c|}
\hline Test substance & Water & Water solubility $(\mu \mathrm{g} / \mathrm{l})^{*}$ & Reference \\
\hline$\alpha-H B C D D$ & \multirow[t]{4}{*}{ Water } & $48.8 \pm 1.9$ & \multirow{4}{*}{$\begin{array}{l}\text { MacGregor and Nixon } \\
(2004)\end{array}$} \\
\hline$\beta-H B C D D$ & & $14.7 \pm 0.5$ & \\
\hline Y-HBCDD & & $2.1 \pm 0.2$ & \\
\hline $\begin{array}{l}\text { HBCDD technical product, } \\
\text { sum of above }\end{array}$ & & 65.6 & \\
\hline$\alpha-H B C D D$ & \multirow{4}{*}{$\begin{array}{l}\text { Salt-water } \\
\text { medium }\end{array}$} & 34.3 & \multirow[t]{4}{*}{ Desjardins et al. (2004) } \\
\hline$\beta-H B C D D$ & & 10.2 & \\
\hline Y-HBCDD & & 1.76 & \\
\hline $\begin{array}{l}\text { HBCDD technical product, } \\
\text { sum of above }\end{array}$ & & 46.3 & \\
\hline $\mathrm{Y}-\mathrm{HBCDD}$ & Water & $3.4 \pm 2.3^{* *}$ & $\begin{array}{l}\text { Stenzel and Markley } \\
\text { (1997) }\end{array}$ \\
\hline
\end{tabular}

${ }^{*} 20^{\circ} \mathrm{C},{ }^{* *} 25^{\circ} \mathrm{C}$ 


\section{Information on hexabromocyclododecane in relation to the POP screening criteria}

\subsection{Persistence}

\subsubsection{Test results}

Abiotic degradation

Photochemical degradation half-life of HBCDD in the atmosphere is estimated by AopWin v1.91 to be 76.8 hours (3.2 days). The model estimates the degradation rate for reaction with hydroxyl radicals. The estimate was obtained by assuming a concentration of $5 * 10^{5} \mathrm{OH}-$ molecules $/ \mathrm{cm}^{3}$ and that the reaction takes place 24 hours in a day (these are values used in the Europen Union risk assessments). It is noted, that the model is sensitive to the chosen $\mathrm{OH}$-concentration. With a concentration of $7 * 10^{6} \mathrm{OH}$-molecules $/ \mathrm{cm}^{3}$ a degradation half-life of 0.23 days result. The model is not able to estimate other reactions (such as with ozone or $\mathrm{NH}_{4}$ ) in air for HBCDD and the estimates illustrate only the rate of hydrogen abstraction, which is primary degradation.

Hydrolysis can be assumed to be an insignificant degradation route for HBCDD due to its very low water solubility. In theory, an aliphatic brominated substance may undergo abiotic debromination via Lewis base catalysis, when exposed to sunlight and air and via nucleofilic reactions (Kirk-Othmer, 1993). HBCDD has been observed to degrade abiotically. Experimental data on abiotic degradation of HBCDD are available from abiotic controls of biodegradation tests of Davis et al. (2003a,b and 2004; seeTables $4.2 \mathrm{a}$ and $\mathrm{b}$ ).

\section{Biodegradation}

A good experimental dataset on biodegradation is available for HBCDD covering several biodegradation screening tests and degradation simulation tests. Of these, the degradation simulation tests (see Tables 4.2a,b) provide more relevant information on the degradation rate of the substance in the environment, whereas the other studies give useful background information on the degration route, degradation products and on the behaviour in waste water treatment plants. 
The estimation models Biowin5 and Biowin6 (in EpiSuite v3.12) are able to take the aliphatic cyclic structure of HBCDD into account in the estimation of the biodegradation rate. Both models predict that the substance is not biodegrading fast (results -0.43 and 0.00 for the models 5 and 6, respectively). Biowin 1 to 4 models are less reliable as they do not correct for the cyclic structure.

No biodegradation was observed within 28 days in an OECD 301D (closed bottle) test according to Schaefer and Haberlein (1996). The test was carried out at a test concentration of $7.7 \mathrm{mg} / 1$ with a composite sample consisting of HBCDD of three producers as test substance. Other reliable ready biodegradability test results are not available.

HBCDD is considered to be not readily biodegradable based on the available information.

Inherent biodegradation test results of Davis et al. (2004) employing sludge from Midland, Michigan (U.S.), municipal waste water treatment plant and using the OECD 302B standard are presented in Table 4.1. The test substance was a composite sample of three manufacturers. The composition of the sample was $8.68,6.12$ and $85.19 \%$ of $\alpha-, \beta$ - and $\gamma$ HBCDD, respectively. ${ }^{14} \mathrm{C}-\mathrm{HBCDD}$ was labelled at the minimum at the 1-, 5- and 9- positions. The composition of the final ${ }^{14} \mathrm{C}-\mathrm{HBCDD}$ was 7.74, 7.84 and $81.5 \%$ of $\alpha-, \beta-$ and $\gamma-$ HBCDD, respectively. Both HBCDD and ${ }^{14} \mathrm{C}$-HBCDD were dissolved in acetone for stock solutions. Recovery of ${ }^{14} \mathrm{C}$ from the extractable fractions was generally good. Primary degradation of HBCDD was observed to proceed considerably faster in anaerobic than in aerobic conditions both in viable and abiotic batches. No systematic differences in the degradation rates of single diastereomers could be observed in the tests, although differences within each test were detected. 
Table 4.1 Overview of the inherent biodegradation tests according to OECD 302B (Davis et al. 2004)

\begin{tabular}{|c|c|c|}
\hline & Aerobic activated sludge & Anaerobic digester sludge \\
\hline Test guideline & OECD 302B & ISO 11734 \\
\hline Test concentration & $3.6 \mathrm{mg} / \mathrm{l}$ (nominal) & $4.2 \mathrm{mg} / \mathrm{l}$ (nominal) \\
\hline Test duration & 56 days & 60 days \\
\hline Temperature & $22 \pm 3{ }^{\circ} \mathrm{C}$ & $35 \pm 2{ }^{\circ} \mathrm{C}$ (in darkness) \\
\hline $\begin{array}{l}\text { Concentration of suspended } \\
\text { solids }\end{array}$ & & $2130 \mathrm{mg} / \mathrm{l}$ \\
\hline Control tests & $\begin{array}{l}{ }^{14} \text { C-benzoate (degr. reference); } \\
\text { HBCDD (inhibition control), } \\
\text { acetone (solvent control) }\end{array}$ & $\begin{array}{l}{ }^{14} \text { C-benzoate (degr. reference); } \\
\text { HBCDD (inhibition control), } \\
\text { acetone (solvent control), } \\
\text { inoculum only -control }\end{array}$ \\
\hline \multirow[t]{4}{*}{$\begin{array}{l}\text { Substance monitoring (sludge and } \\
\text { headspace) }\end{array}$} & $\begin{array}{l}{ }^{14} \mathrm{C}-\mathrm{HBCDD}(\alpha, \beta, \gamma) \text { (days } 0, \\
17,14,28 \text { and } 56)\end{array}$ & $\begin{array}{l}{ }^{14} \mathrm{C}-\mathrm{HBCDD}(\alpha, \beta, \gamma) \text { (days } 0, \\
5,7,14,21,28 \text { and } 60)\end{array}$ \\
\hline & $\begin{array}{l}{ }^{14} \mathrm{C} \text {-products (days } 0,17,14,28 \\
\text { and } 56 \text { ) }\end{array}$ & $\begin{array}{l}{ }^{14} \mathrm{C} \text {-products (days } 0, \\
5,7,14,21,28 \text { and } 60 \text { ) }\end{array}$ \\
\hline & ${ }^{14} \mathrm{CO}_{2}$ (weekly) & ${ }^{14}$ C-volatiles ("routinely") \\
\hline & $\begin{array}{l}\text { Equipment: HPLC-RAM, LSC, } \\
\text { GC-RAM }\end{array}$ & $\begin{array}{l}\text { Equipment: HPLC-RAM, LSC, } \\
\text { GC-RAM }\end{array}$ \\
\hline \multicolumn{3}{|l|}{$\begin{array}{l}\text { Disappearance of }{ }^{14} \mathrm{C}-\mathrm{HBCDD} \\
(\alpha+\beta+\gamma) \text { expressed as decrease in } \\
\text { radioactivity ( } \% \text { of initial nominal) }\end{array}$} \\
\hline in viable flasks & From $99 \%$ to $78 \%$ & From $114 \%$ to $15 \%$ \\
\hline in abiotic flasks & From 100 to $40 \%$ & From $97 \%$ to $6 \%$ \\
\hline \multirow[t]{2}{*}{ Comment } & $\begin{array}{l}\text { Sterilisation of abiotic flasks was } \\
\text { done with mercuric chloride; } \\
\text { unlikely to have impact on the } \\
\text { disappearance results via Cl-Br- } \\
\text { replacement as the results } \\
\text { reflect }{ }^{14} \mathrm{C} \text {-HBCDD disappea- } \\
\text { rance measured with HPLC-UV- } \\
\text { RAM }\end{array}$ & $\begin{array}{l}\text { Sterilisation of abiotic flasks } \\
\text { was done by autoclaving ( } 30 \\
\left.\text { min. at } 121^{\circ} \mathrm{C} \text { and } 15 \mathrm{psi}\right)\end{array}$ \\
\hline & & $\begin{array}{l}\text { At day } 60,30 \% \text { of the remai- } \\
\text { ning readioactivity was recove- } \\
\text { red in the rubber stoppers and } \\
\text { originated mainly from dibromo- } \\
\text { cyclododecadiene and } 1,5,9- \\
\text { cyclododecatriene (pers. comm } \\
\text { with industry as cited in Euro- } \\
\text { pean Commission, } 2007 \text { ) }\end{array}$ \\
\hline
\end{tabular}

Gerecke et al. (2006) conducted degradation tests under anaerobic conditions using domestic sludge from a mesophilic digester and $\alpha-, \beta$ - and $\gamma$ HBCDD and a technical HBCDD mixture individually as test substances. Each of the diastereomers consisted of a racemic mixture of the enantiomer pairs. The tests were run parallel in three sets: 1) no nutrient additions; three primers added 2) nutrient additions (yeast $50 \mathrm{mg}$ and starch $20 \mathrm{mg}$ ) and 3) like 2) but also three primers added. The tests were run at a temperature of $37{ }^{\circ} \mathrm{C}$. The test concentrations were not provided by the authors but they were $<1 \mathrm{mg} / \mathrm{l}$ based on the description of the experimental setting. The test with technical HBCDD mixture resulted a (primary degradation) half-life of $1.6 \mathrm{~d}$, whereas $(+/-) \beta$ - and (+/-) $\gamma$-HBCDD degraded according to the authors faster than $(+/-) \alpha-\mathrm{HBCDD}$, by a factor of 
approximately 1.6 and 1.8, respectively. Because the test conditions are not comparable with the standard screening biodegradation tests, the results cannot be used to extrapolate environmentally relevant degradation rates. However, the study results demonstrate, that there are differences in the anaerobic degradation rates of the three diastereomers and that HBCDD is degraded fast in favourable anaerobic conditions. Based on the water solubility and $\operatorname{logKow}, \alpha$-HBCDD should be the most available diastereomer for degradation in aqueous media, but this diastereomer was degrading in the study at the slowest rate. Hence, the differences in the degradation rates cannot be caused by mass transfer limitations.

Standard degradation simulation tests have been conducted in two large studies for sediment and soil in anaerobic and aerobic conditions. The main conditions and results are summarised in Tables 4.2a and b. All tests of the two studies employed $\alpha-, \beta$ - and $\gamma$-HBCDD mixtures representative of the commercial HBCDD as test substances.

The earlier study (Davis et al., 2003a,b) was conducted using low test concentrations close to the present environmental contamination levels. As a consequence, concentrations of $\alpha$ - and $\beta$-diastereomers could not be analysed and the results show the degradation of $\gamma$-HBCDD, only. In the study of Davis et al. (2004), 100-fold higher test concentrations and ${ }^{14} \mathrm{C}$ labelling were used in order to be able to monitor the disappearance of all three diastereomers and to identify and quantify degradation products. The analyses were carried out from duplicate microcosms and the results in Tables $4.2 \mathrm{a}$ and $\mathrm{b}$ reflect their average.

In both studies HBCDD disappeared fastest in anaerobic, viable microcosms followed by abiotic controls. The disappeareance was clearly slower in aerobic vial batches than in anaerobic microcosms and at the slowest it was in the abiotic controls of the aerobic tests. HBCDD disappeared significantly faster in the study of Davis et al. (2003a,b) than in the corresponding tests of Davis et al. (2004).

There are several reasons for considering the results of Davis et al. (2004) more reliable than the earlier simulation tests of Davis et al. (2003a,b). Firstly, no mass balance could be made and the recovery was generally bad at the start in the tests of Davis et al. (2003a,b). Therefore, dissipation to non-extractable residues and problems with extraction may have influenced the results. Furthermore, brominated degradation products were not detected at any time in the microcosms according to the authors.

In the degradation simulation tests of Davis et al. (2004) a mass balance could be derived. Non-extractable adsorption to soil occurred only in the viable aerobic microcorsms, which encountered for the ${ }^{14} \mathrm{C}$ HBCDD losses observed in the extract. In abiotic control of the aerobic soil test and in the sediment tests the radioactivity was recovered in the extracts at a good level throughout the study. The authors could also follow the emergence of several degradation products. The amount of 
HBCDD mineralised (measured as ${ }^{14} \mathrm{CO}_{2}$ ) and other volatile ${ }^{14} \mathrm{C}$ degradation products was monitored and remained negligible in all tests. Additionally, Davis et al. (2004) observed, that $\alpha$-HBCDD was degraded more slowly in the sediment test than $\beta$ - and $\gamma$-HBCDD.

Primary degradation half-lives were derived by the Rapporteur of the EU risk assessment using the results of the study of Davis et al. (2004) and they are presented in Table 4.3. Table 4.2a Overview of the degradation simulation tests of Davis et al. (2003a,b). 


\begin{tabular}{|c|c|c|c|c|c|c|c|c|c|c|c|}
\hline \multirow[t]{2}{*}{ Medium/Standard } & \multirow[t]{2}{*}{ Sampling site } & \multirow[t]{2}{*}{$\begin{array}{l}\text { Nominal test } \\
\text { conc. (mg/kg dw) }\end{array}$} & \multirow[t]{2}{*}{ Duration } & \multirow[t]{2}{*}{ Temp. } & \multirow[t]{2}{*}{$\begin{array}{l}\text { Analytical method, } \\
\text { detection limit }\end{array}$} & \multicolumn{2}{|c|}{$\begin{array}{l}\text { Measured HBCDD conc. (ng/g } \\
\text { dw), viable microcosms }\end{array}$} & \multicolumn{2}{|c|}{$\begin{array}{l}\text { Measured HBCDD conc. (ng/g } \\
\text { dw), abiotic microcosms }\end{array}$} & \multirow[t]{2}{*}{ Comments } & \multirow[t]{2}{*}{ Author } \\
\hline & & & & & & Day 0 & Termination & Day 0 & Termination & & \\
\hline $\begin{array}{l}\text { Aerobic sedi- } \\
\text { ment/OECD } 308\end{array}$ & $\begin{array}{l}\text { Schyukill River, Valley } \\
\text { Forge, Pennsylvania, } \\
\text { U.S. }\end{array}$ & 0.034 & 119 & $20 \pm 1^{\circ} \mathrm{C}$ & $\begin{array}{l}\text { HPLC-MS, } 0.5 \mathrm{ng} \\
\text { HBCDD/g dw } \\
\text { GC-MS }\end{array}$ & $31.9 \pm 2.5$ & $3.3 \pm 4.6$ & $31.3 \pm 0.5$ & $20.7 \pm 0.7$ & 1) 3) & $\begin{array}{l}\text { Davis et al. } \\
\text { (2003a) }\end{array}$ \\
\hline $\begin{array}{l}\text { Anaerobic sediment/ } \\
\text { OECD } 308\end{array}$ & $\begin{array}{l}\text { Schyukill River, Valley } \\
\text { Forge, Pennsylvania, } \\
\text { U.S. }\end{array}$ & 0.063 & 119 & $20 \pm 1^{\circ} \mathrm{C}$ & $\begin{array}{l}\text { HPLC-MS } 0.5 \mathrm{ng} \\
\text { HBCDD/ g dw } \\
\text { GC-MS }\end{array}$ & $27.7 \pm 6.7$ & n.d. & $27.2 \pm 1.6$ & n.d. & 1) 3) & $\begin{array}{l}\text { Davis et al. } \\
\text { (2003a) }\end{array}$ \\
\hline $\begin{array}{l}\text { Aerobic sedi- } \\
\text { ment/OECD } 308\end{array}$ & $\begin{array}{l}\text { Neshaminy Creek, } \\
\text { Pennsylvania, U.S. }\end{array}$ & 0.060 & 119 & $20 \pm 1^{\circ} \mathrm{C}$ & $\begin{array}{l}\text { HPLC-MS, } 0.5 \mathrm{ng} \\
\text { HBCDD/g dw } \\
\text { GC-MS }\end{array}$ & $80.7 \pm 5.8$ & $9.2 \pm 4.1$ & $58.3 \pm 10.0$ & $2.7 \pm 3.8$ & 1) 2), 3) & $\begin{array}{l}\text { Davis et al. } \\
\text { (2003a) }\end{array}$ \\
\hline $\begin{array}{l}\text { Anaerobic sediment/ } \\
\text { OECD } 308\end{array}$ & $\begin{array}{l}\text { Neshaminy Creek, } \\
\text { Pennsylvania, U.S. }\end{array}$ & 0.089 & 119 & $20 \pm 1^{\circ} \mathrm{C}$ & $\begin{array}{l}\text { HPLC-MS, } 0.5 \mathrm{ng} \\
\text { HBCDD/g dw } \\
\text { GC-MS }\end{array}$ & $39.1 \pm 5.4$ & n.d. & $37.5 \pm 6.6$ & $1.4 \pm 2.0$ & 1) 2) 3) & $\begin{array}{l}\text { Davis et al. } \\
\text { (2003a) }\end{array}$ \\
\hline $\begin{array}{l}\text { Aerobic soil /OECD } \\
307\end{array}$ & $\begin{array}{l}\text { Northwood, North } \\
\text { Dakota, U.S. }\end{array}$ & 0.025 & 119 & $20 \pm 1^{\circ} \mathrm{C}$ & $\begin{array}{l}\text { HPLC-MS, } 0.5 \mathrm{ng} \\
\text { HBCDD/g dw } \\
\text { GC-MS }\end{array}$ & $15.9 \pm 1.3$ & $4.0 \pm 1.1$ & 18.0 & $17.4 \pm 7.5$ & 4) & $\begin{array}{l}\text { Davis et al. } \\
\text { (2003b) }\end{array}$ \\
\hline $\begin{array}{l}\text { Anaerobic soil /OECD } \\
307\end{array}$ & $\begin{array}{l}\text { Northwood, North } \\
\text { Dakota, U.S. }\end{array}$ & 0.025 & 119 & $20 \pm 1^{\circ} \mathrm{C}$ & $\begin{array}{l}\text { HPLC-MS, } 0.5 \mathrm{ng} \\
\text { HBCDD/g dw } \\
\text { GC-MS }\end{array}$ & $11.0 \pm 0.1$ & n.d. & $17.2 \pm 2.5$ & $6.9 \pm 1.9$ & 4) & $\begin{array}{l}\text { Davis et al. } \\
\text { (2003b) }\end{array}$ \\
\hline
\end{tabular}

1) Several deviations from standard conditions; likely to have little influence on the results

2) Interfering peak detected in non-spiked microcosms indicating a possible presence of initial HBCDD contamination of the river sediment. Based on the detected background interference, average concentration of the interfering peak, i.e., in aerobic viable microcosms was estimated at $19.5+-3.0 \mathrm{ng} / \mathrm{g}$ sediment (dwt) at days 0,7 and 119 . All test results were corrected accordingly.

3) No brominated degradation products were detected in water, sediment or headspace. The quantification of bromide released to water phase from degradation was not possible due to > 100 -fold background bromide concentration.

4) Sandy loam (OC $1.8 \%$ ) n.d. = not detected 
Table 4.2b Overview of the degradation simulation tests of Davis et al. (2004).

\begin{tabular}{|c|c|c|c|c|c|c|c|c|c|c|c|}
\hline \multirow[t]{2}{*}{ Medium/Standard } & \multirow[t]{2}{*}{ Sampling site } & \multirow[t]{2}{*}{ Nominal test conc. (mg/kg dw) } & \multirow[t]{2}{*}{ Duration } & \multirow[t]{2}{*}{ Temp. } & \multirow[t]{2}{*}{$\begin{array}{l}\text { Analytics, } \\
\text { detection limit }\end{array}$} & \multicolumn{3}{|c|}{$\begin{array}{l}\text { HBCDD conc. as } \% \text { of initial nominal concentra- } \\
\text { tion, viable microcosms }\end{array}$} & \multicolumn{2}{|c|}{$\begin{array}{l}\text { HBCDD conc. as \% of initial } \\
\text { nominal concentration, } \\
\text { abiotic microcosms }\end{array}$} & \multirow[t]{2}{*}{ Comments } \\
\hline & & & & & & & Day $0(\%)$ & $\begin{array}{l}\text { Termination } \\
\text { (\%) }\end{array}$ & Day $0(\%)$ & $\begin{array}{l}\text { Termination } \\
(\%)\end{array}$ & \\
\hline \multirow{4}{*}{$\begin{array}{l}\text { Aerobic sedi- } \\
\text { ment/OECD } 308\end{array}$} & \multirow{4}{*}{$\begin{array}{l}\text { Schyukill River, } \\
\text { Valley Forge, Penn- } \\
\text { sylvania, U.S. }\end{array}$} & \multirow[t]{4}{*}{4.67} & \multirow[t]{4}{*}{112} & \multirow{4}{*}{$\begin{array}{l}20 \pm 2 \\
{ }^{\circ} \mathrm{C}\end{array}$} & \multirow{4}{*}{$\begin{array}{l}\text { HPLC-UV- } \\
\text { RAM, } 0.8 \% \text { of } \\
\text { initial r.a. } \\
\text { GC-RAM } \\
\text { LSC }\end{array}$} & Total & $95.4 \pm 4.6$ & $53.3 \pm 9.7$ & $100.2 \pm 16.5$ & $84.5 \pm 5.4$ & \\
\hline & & & & & & $\alpha-H B D D$ & $9.0 \pm 1.0$ & $5.1 \pm 0.6$ & $9.3 \pm 2.0$ & $8.6 \pm 1.3$ & \\
\hline & & & & & & $\beta-H B C D D$ & $8.0 \pm 1.1$ & $4.0 \pm 0.7$ & $9.0 \pm 1.9$ & $6.8 \pm 0.8$ & \\
\hline & & & & & & $\mathrm{y}$-HBCDD & $78.4 \pm 2.6$ & $44.1 \pm 8.5$ & $81.9 \pm 12.6$ & $69.1 \pm 3.4$ & \\
\hline \multirow{4}{*}{$\begin{array}{l}\text { Anaerobic sedi- } \\
\text { ment/ OECD } 308\end{array}$} & \multirow{4}{*}{$\begin{array}{l}\text { Schyukill River, } \\
\text { Valley Forge, Penn- } \\
\text { sylvania, U.S. }\end{array}$} & \multirow[t]{4}{*}{4.31} & \multirow[t]{4}{*}{113} & \multirow{4}{*}{$\begin{array}{l}20 \pm 2 \\
{ }^{\circ} \mathrm{C}\end{array}$} & \multirow{4}{*}{$\begin{array}{l}\text { HPLC-UV- } \\
\text { RAM, } 0.8 \% \text { of } \\
\text { initial r.a. } \\
\text { GC-RAM } \\
\text { LSC }\end{array}$} & Total & $95.6 \pm 2.2$ & $37.0 \pm 6.9$ & $111.7 \pm 3.5$ & $74.7 \pm 6.0$ & \\
\hline & & & & & & $\alpha-H B D D$ & $9.0 \pm 0.6$ & $4.4 \pm 1.8$ & $10.3 \pm 1.9$ & $8.9 \pm 1.2$ & \\
\hline & & & & & & $\beta-H B C D D$ & $8.0 \pm 0.9$ & $1.4 \pm 0.6$ & $10.6 \pm 0.3$ & $5.2 \pm 0.7$ & \\
\hline & & & & & & $\mathrm{y}$-HBCDD & $78.6 \pm 3.8$ & $31.2 \pm 5.0$ & $90.8 \pm 1.8$ & $60.6 \pm 7.9$ & \\
\hline \multirow{4}{*}{$\begin{array}{l}\text { Aerobic soil } \\
\text { /OECD } 307\end{array}$} & \multirow{4}{*}{$\begin{array}{l}\text { Northwood, North } \\
\text { Dakota, U.S. }\end{array}$} & \multirow[t]{4}{*}{3.0} & \multirow[t]{4}{*}{112} & \multirow{4}{*}{$\begin{array}{l}20 \pm 2 \\
{ }^{\circ} \mathrm{C}\end{array}$} & \multirow{2}{*}{$\begin{array}{l}\text { HPLC-UV- } \\
\text { RAM, } 0.4 \% \text { of } \\
\text { initial r.a. }\end{array}$} & Total & $97.6 \pm 0.2$ & $88.2 \pm 1.4$ & $109.7 \pm 4.1$ & $102.8 \pm 0.2$ & 1 \\
\hline & & & & & & $\alpha-H B D D$ & $8.6 \pm 0.5$ & $8.2 \pm 0.2$ & $10.0 \pm 0.6$ & $8.6 \pm 0.2$ & \\
\hline & & & & & GC-RAM & $\beta-H B C D D$ & $8.3 \pm 0.5$ & $7.5 \pm 0.3$ & $9.5 \pm 0.2$ & $8.7 \pm 0.1$ & \\
\hline & & & & & LSC & $\mathrm{y}-\mathrm{HBCDD}$ & $80.7 \pm 0.9$ & $72.6 \pm 1.1$ & $90.2 \pm 3.3$ & $85.5 \pm 0.2$ & \\
\hline
\end{tabular}

1) Sandy loam (OC $1.8 \%$ ) 


\begin{tabular}{|c|c|c|c|}
\hline Medium/Standard & Sampling site & $\begin{array}{l}\text { Degradation half-life of } H B C D D \text { in } \\
\text { viable flasks (value in parenthesis } \\
\left.\text { corrected to } 12^{\circ} \mathrm{C}\right)^{a}\end{array}$ & $\begin{array}{l}\text { Dgradation half-life of } \\
\text { HBCDD in abiotic flasks } \\
\text { (value in parenthesis } \\
{\text { corrected to } 12^{\circ} \mathrm{C} \text { ) }}^{\mathrm{b}}\end{array}$ \\
\hline $\begin{array}{l}\text { Aerobic sedi- } \\
\text { ment/OECD } 308\end{array}$ & $\begin{array}{l}\text { Schyukill River, } \\
\text { Valley Forge, } \\
\text { Pennsylvania, U.S. }\end{array}$ & $\begin{array}{l}\text { Total HBCDD: } 101 \mathrm{~d}(191 \mathrm{~d}) \\
\text { a-HBCDD: } 113 \mathrm{~d}(214 \mathrm{~d}) \\
\text { ß-HBCDD: } 68 \mathrm{~d}(129 \mathrm{~d}) \\
\text { Y-HBCDD: } 104 \mathrm{~d}(197 \mathrm{~d})\end{array}$ & Not estimated \\
\hline $\begin{array}{l}\text { Anaerobic sedi- } \\
\text { ment/ OECD } 308\end{array}$ & $\begin{array}{l}\text { Schyukill River, } \\
\text { Valley Forge, } \\
\text { Pennsylvania, U.S. }\end{array}$ & $\begin{array}{l}\text { Total HBCDD: } 66 \mathrm{~d}(125 \mathrm{~d}) \\
\text { a-HBDD: } 113 \mathrm{~d} \\
\text { ß-HBCDD: } 44 \mathrm{~d} \\
\text { Y-HBCDD: } 65 \mathrm{~d}\end{array}$ & Not estimated \\
\hline $\begin{array}{l}\text { Aerobic soil } \\
\text { /OECD } 307\end{array}$ & $\begin{array}{l}\text { Northwood, North } \\
\text { Dakota, U.S. }\end{array}$ & - (no degradation) & -(no degradation) \\
\hline
\end{tabular}

Half-lives, which should be understood as disappearance half-lives (not as degradation half-lives) of $\gamma$-HBCDD due to the shortages mentioned above, were derived also in the study of Davis et al. (2003a,b). These were in the anaerobic and aerobic viable Schyukill sediment tests 1.5 and 11 days, respectively. For the Neshaminy Creek sediment, half-lives in anaerobic and aerobic viable test were 1.1 and 32 days, respectively. In the anaerobic and aerobic viable soil tests the disappeareance half-lives were 7 and 63 days, respectively.

It is noted, that only one soil type was used in the soil degradation simulation tests, whereas the standard would require the use of at least four soil types.

Degradation products

Davis et al. (2004) conducted a supplemental test using anaerobic digester sludge for the initial identification of HBCDD's transformation products. ${ }^{14} \mathrm{C}$-HBCDD in acetone was mixed with HBCDD in the test vials and acetone was allowed to evaporate. Sludge was added to a concentration of $3400 \mathrm{mg} \mathrm{SS} / 1$, and the bottles were sealed with Tefloncoated septa. Test concentrations were $0,1,50,100$ and $500 \mathrm{mg} / 1$ and the bottles were incubated in the dark at $35^{\circ} \mathrm{C}$. Samples of reaction mixture were analysed for ${ }^{14} \mathrm{C}$-HBCDD and ${ }^{14} \mathrm{C}$-products at frequent intervals. After 106 days the remaining 0 and $500 \mathrm{mg} \mathrm{HBCDD} / 1$-mixtures were extracted overnight with acetonitrile and the extract was concentrated by solid phase extraction. Transformation products were identified as tetrabromocyclododecene (product I), dibromocyclododecadiene (product II) and 1,5,9-cyclododecatriene (product III). 1,5,9-cyclododecatriene is the raw material for the production of HBCDD. The proposed pathway for degradation is shown in Figure 4.1. 


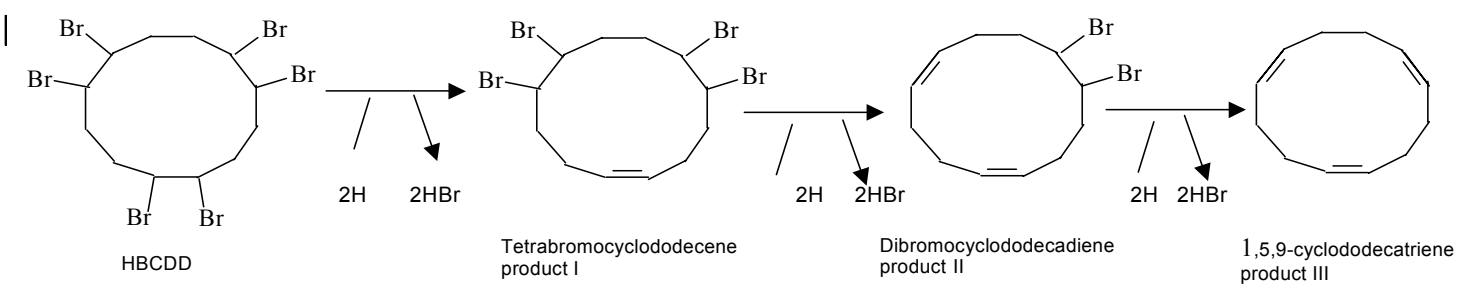

Figure 4.1 Suggested degradation path of HBCDD (Davis et al., 2004).

Davis et al. (2004) identified and quantified the above described degradation products of ${ }^{14} \mathrm{C}-\mathrm{HBCDD}$ also in their standard sediment and sludge degradation tests. Based on Davis et al. (2004), dehalogenation is caused by reducing conditions and the same degradation products are formed in sludge and in the aquatic environment.

The known properties of the identified main degradation product 1,5,9-cyclododecatriene (CAS 4904-61-4 and CAS 4904-62-2) are presented in Appendix 4.

\subsubsection{Evidence from measured levels in the environment}

Kohler et al. (2006) analysed HBCDD from dated sediment cores. They found HBCDD in one Lake Greifensee $(\mathrm{CH})$ sediment core, sampled at a depth of $31 \mathrm{~m}$, at concentrations of $2.5 \mu \mathrm{g} / \mathrm{kg} \mathrm{dw}$ at the surface (year $2001), 1.8 \mu \mathrm{g} / \mathrm{kg} \mathrm{dw}$ in a layer sedimented in $1995,1.2 \mu \mathrm{g} / \mathrm{kg} \mathrm{dw}$ in a layer sedimented in 1989 and $0.25 \mu \mathrm{g} / \mathrm{kg} \mathrm{dw}$ (LOD) or lower in layers sedimented in 1982 and 1974. As the exposure of sediment for the same years cannot be estimated retrospectively, it is not possible to estimate degradation half-life from the sediment core. However, it is likely, that the exposure has not been considerably higher in the earlier years than in the year 2001, but more likely even lower based on the increased market volumes of brominated flame retardants in the last decades.

Figure 4.2 presents a comparison of the results of Kohler et al. (2006) with sediment concentrations calculated using the aerobic and anaerobic half-lives derived from studies of Davis et al. (2003a) and Davis et al. (2004) and converted to $12{ }^{\circ} \mathrm{C}$. For this direct comparison it must be assumed, that the exposure in each year of sedimentation has been equal for each profile. As freshwater lakes such as Greifensee have typically a shallow aerobic top sediment layer beyond the anaerobic sediment, the aerobic half-lives for the two sediment profile estimations were used for the calculation of the concentration drop for one year old sediment, whereas anaerobic half-lives were used for the older sediment layers.

Based on the illustration, the difference in the measured and estimated concentrations is too large that it could be explained by uncertainties in the exposure assumption or in the sediment dating. The comparison indicates, that the experimental half-lives are not directly applicable for Lake 
Greifensee sediment but the actual half-life has been considerably longer than what would be expected based on the experimental half-lives.

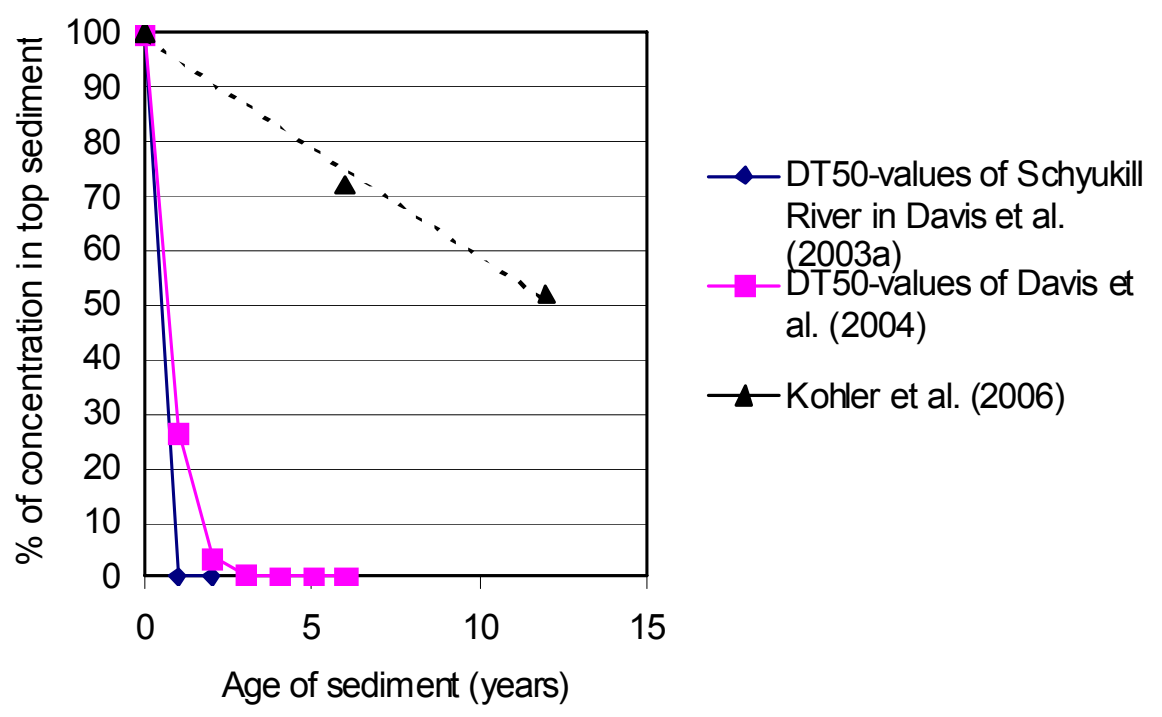

Figure 4.2. Relative concentrations of $H B C D D$ (as \% of initial conc.) in two hypothetical and one measured sediment core. Half-lives of Davis et al. (2003a) and Davis et al. (2004) were corrected to $12{ }^{\circ} \mathrm{C}$.

Christensen et al. (2004), Fjeld et al (2006b), Remberger et al. (2004) and Sternbeck et al. (2001) have also measured sediment samples of different ages. Despite the uncertainties embedded to the dating of the sediment samples, the results provide an indication of a slower apparent decrease of HBCDD concentrations with time compared to what would be expected based on the half-lives obtained from biodegradation simulation tests.

Furthermore, HBCDD has been found in abiotic and biotic samples of even the most remote areas (see Table 4.10). These findings provide additional evidence, that HBCDD can persist in the environment long enough, to be transported over long distances.

\subsubsection{Summary and conclusions}

HBCDD is not readily biodegradable according to a standard OECD 301D -test (Schaefer and Haberlein (1996). In the degradation simulation tests with sediment (Davis et al., 2004), $(\alpha+\beta+\gamma)$-HBCDD was observed to be subject to primary degradation with half-lives of 66 and 101 days in anaerobic and aerobic sediment at $20{ }^{\circ} \mathrm{C}$, respectively. These half-lives corresponded with 125 and 191 days, after a temperature correction to 12 ${ }^{\circ} \mathrm{C}$ was made. Degradation half-lives in aerobic sediment were calculated at $20{ }^{\circ} \mathrm{C}$ to be 113,68 and 104 days for $\alpha-, \beta$ - and $\gamma$-HBCDD, respectively. The temperature corrected values at $12{ }^{\circ} \mathrm{C}$ were 214,129 and 197 days. 
Based on the investigations of Davis et al. (2004) and Gerecke et al. (2006), $\alpha$-HBCDD seems to be subject to a slower degradation than $\beta$ and $\gamma$-HBCDD.No degradation was observed in the aerobic soil degradation simulation test of Davis et al. (2004).

Davis et al. (2004) identified the primary degradation products to be products of stepwise dehalogenation. They observed a formation of tetrabromocyclododecane, dibromocyclododecadiene and 1,5,9cyclododecatriene. For this reaction, anaerobic conditions with biological acitivity seem to be favourable, but dehalogenation was also observed in aerobic and abiotic conditions, although with significantily slower disappearance rates of HBCDD.

The main dehalogenation product, 1,5,9-cyclododecatriene (CDT; CAS 4903-66-4), is not readily biodegradable, but based on an enhanced ready biodegradation test modified from OECD $301 \mathrm{~F}$ the substance was observed to be mineralised completely in 63-77 days (see Appendix 3).

HBCDD is abundant in the remote areas in biota and abiotic samples (see Table 4.10). In addition, the concentrations measured in the sediment core samples by Christensen et al. (2004), Fjeld et al (2006b), Kohler et al. (2006), Remberger et al. (2004) and Sternbeck et al. (2001) provide an indication of that HBCDD is degraded in sediment more slowly than predicted by the simulation tests.

The degradation half-lives for aerobic sediment at $12{ }^{\circ} \mathrm{C}$ derived from the available reliable degradation simulation study are for $\alpha$-HBCDD and $\gamma$ HBCDD slightly longer than the POP half-life criteria $(180 \mathrm{~d})$, whereas the corresponding half-lives at $20{ }^{\circ} \mathrm{C}$ are shorter than the criteria. Based on the available reliable degradation simulation study with soil, HBCDD seems to fulfil the POP criteria for soil (no degradation observed). The available measured environmental data from sediment indicate, that the actual sediment halflives in the environment can be longer than what would be expected based on the experimental half-lives. The abundance of HBCDD in biota and abiotic samples of remote regions provides also a solid evidence of the persistency of HBCDD. It is therefore concluded, that HBCDD fulfils the POP screening criteria for persistence. 


\subsection{Bioaccumulation}

\subsubsection{Test results}

Fish

Two reliable test results are available on the bioconcentration of HBCDD in fish.

Veith et al. (1979) determined bioconcentration of HBCDD in fathead minnow (Pimephales promelas) in a 32-day flow-through test. Mean test concentration was $6.2 \mu \mathrm{g} / \mathrm{l}$ and test temperature $25 \pm 0.5{ }^{\circ} \mathrm{C}$. Thirty fish were exposed and five fish analysed at days $2,4,8,16,24$ and 32 . The steady-state BCF was calculated to be 18100 .

Bioconcentration of HBCDD was measured in rainbow trout $(\mathrm{On}$ corhynchus mykiss) in a flow-through test according to OECD 305 standard and in compliance with GLP (Drottar and Krueger, 2000). Duration of exposure and depuration phases was 35 days, respectively, test temperature $12 \pm 1{ }^{\circ} \mathrm{C}$ and test concentrations of $0.34 \mu \mathrm{g} / 1$ (nominal) and 3.4 $\mu \mathrm{g} / \mathrm{l}$ (nominal). For each test concentration one test chamber was run. A third aquarium consisted of a solvent control. For each chamber 85 fish were used.

Measured concentrations in the HBCDD exposed chambers during the uptake phase were 0.18 and $1.8 \mu \mathrm{g} / \mathrm{l}$ (LOQ $0.025 \mu \mathrm{g} / \mathrm{l}$ ) representing $53 \%$ of nominal concentration. Concentrations in fish were measured for edible and non-edible parts. Concentrations in edible parts were approximately three times lower than in non-edibles. The steady-state BCF for whole fish was determined at 13085 for the lower exposure group and 8 974 for the higher exposure group. BCFs determined based on uptake and depuration rates were 21940 (low exposure) and 16450 (high exposure). The BCFs are provided on wet weight basis. The measured concentrations in water varied more than recommended by the standard $( \pm 20 \%$ of mean concentration), which may explain part of the differences in the calculated BCFs. In addition, steady-state was not reached in the low exposure chamber but a "steady-state BCF" was determined based on the measured values on day 35. Estimates (derived with BIOFAC) to reach $90 \%$ of steady-state concentration in edible, inedible and whole fish were 63, 65 and 65 days, and calculated depuration half-lives 19, 20 and 19 days, respectively.

Law et al. (2006a) exposed juvenile rainbow trout (Oncorhynchus mykiss) for 56 days to $\alpha-$, $\beta$ - and $\gamma$-HBCDD in separate aquaria via their diet. A 112-day depuration period followed. A control aquarium without HBCDD exposure was run in addition to aquaria exposed to individual diastereomers. Muscle samples were analysed at various points of uptake and depuration phases. No peaks of debrominated or OH-HBCDD metabolites were found in either the muscle or liver tissue extracts. The 
BMFs for the $\alpha$-, $\beta$ - and $\gamma$-diastereoisomers were calculated to be $9.2,4.3$ and 7.2, respectively.

After the termination of the biomagnification test (day 168) it was observed, that a major part of HBCDD in muscle samples of fish exposed solely to $\beta$-HBCDD was detected in the form of $\alpha$ - and $\gamma$-HBCDD. In the fish exposed to $\gamma$-HBCDD a major part of HBCDD found was $\alpha$ HBCDD. In the fish exposed to $\alpha$-HBCDD, no shift to other diastereomers was found in the distribution. The study shows, that the diastereomeric distribution of HBCDD can be changed by way of bioisomerisation in biological material.

Additionally, Janák et al. (2005b) observed diastereomer and enantiomer selective metabolisation rates in microsomal liver preparations of common dab (Limanda limanda). According to the authors, $\alpha$-HBCDD was least biotransformed of the main three diastereomers tested.

Mammals

In a 90-day repeated dose toxicity study with rats (Chengelis, 2001), concentrations of the diastereomers $\alpha, \beta$ and $\gamma$ were measured on days 2 , $6,9,13,20,27,55,89,104$ and 118 . Test substance was administered by a daily gavage of $1000 \mathrm{mg} / \mathrm{kg}$ bw/d (particulates suspended in corn oil) during 90 days followed by 30 days of depuration. The stereoisomer composition of the test article was $\gamma>>\alpha>\beta$, but the concentrations in adipose tissue were at all time points $\alpha>\gamma>\beta$. Steady state seemed to be reached only in the female group and apparent bioaccumulation factors were calculated based on measured concentrations for day 89 (see Table 4.5). Although the confidence of the results is limited by a low number of animals ( 2 animals/sex/sampling day), the study shows reliably the significantly higher apparent accumulation of $\alpha$-HBCDD. It is noted, that the administration of HBCDD occurred suspended in corn oil, so that part of the substance can be assumed to have not absorbed.

Table 4.5 Relative bioaccumulation factors (BAF) for the three HBCDD diastereomers in an oral 90 days toxicity study (a total dose of $1000 \mathrm{mg}$ commercial HBCDD/kg/day by gavage) (Chengelis, 2001).

\begin{tabular}{|c|c|c|c|}
\hline & $\alpha-H B C D D$ & $\beta-H B C D D$ & $\mathrm{Y}$-HBCDD \\
\hline Composition of administered dose (\%) & 6.4 & 4.5 & 79.1 \\
\hline Administered dose (mg/kg/day) & 64 & 45 & 791 \\
\hline $\begin{array}{l}\text { Concentration in female adipose tissue, day } 89 \\
(\mu \mathrm{g} / \mathrm{g} \mathrm{ww})\end{array}$ & 4340 & 357 & 544 \\
\hline Apparent bioaccumulation factor ${ }^{a}$ & 68 & 7.9 & 0.69 \\
\hline Relative BAF ( $\mathrm{\gamma}-\mathrm{HBCDD}$ set to1) & 99 & 11 & 1 \\
\hline
\end{tabular}

${ }^{a}$ The administered dose is normally expressed as a concentration in the diet (in the same unit as the concentration in the adipose tissue is expressed), and the BAF is calculated as concentration in fat divided by the concentration in the diet. Since the dose is given by gavage in the study above, only an apparent relative bioaccumulation factor can be calculated. 
In a study of $\mathrm{Yu}$ and Atallah (1980), the absorption, distribution, excretion, and metabolism of $\gamma$-HBCDD were investigated in Sprague-Dawley rats after a single oral dose of ${ }^{14} \mathrm{C}-\gamma$-HBCDD diluted 1:10 with technical HBCDD (7-9 $\mathrm{mg}$ total HBCDD/kg in acetone:olive oil 2.1:4.1). With the dosing method used, HBCDD is assumed to have dissolved completely to the administered medium. The rats, 8 females and 2 males, were sacrificed $8,24,48$, and 72 hours (females) and 48 hours (males) after dosing. The main results of the study are, that most of HBCDD was distributed to adipose tissue followed by muscle and liver and that a high degree of absorption and metabolism took place. After 3 days, $93 \%$ of initial radioactivity was excreted as (unidentified) metabolites, the main part of it in faeces.

Zegers et al. (2004) analysed the three main diastereomers of HBCDD by LC/MS in the blubber of female harbour porpoises (Phocoena phocoena) and common dolphins (Delphinus delphis) stranded on Western European coasts between Scotland (UK) and Galicia in Spain. All 19 samples anaysed (10 harbour porpoises and 9 common dolphins) contained exclusively the $\alpha$-diastereomer.

The possible influence of cytochrome $\mathrm{P} 450$ mediated biotransformation on the observed difference of the fingerprint of $\alpha-, \beta$ - and $\gamma$-HBCD in the blubber compared to the commercial mixture was investigated with hepatic microsomes of rat and harbour seal (Phoca vitulina) in vitro. Four replicate preparations of phenobarbital induced rat microsomes exposed to an artificial 1:1:1 mixture of the three diastereomers were analysed. The chromatograph peaks of the $\beta$ - and $\gamma$-diastereomers showed a significant decrease during the course of the test, but the peak of the $\alpha$ diastereomer had not become significantly smaller even after 90 minutes incubation at $37^{\circ} \mathrm{C}$. Very similar results were found when harbour seal hepatic microsomes were tested. For $\beta$-HBCDD, three brominecontaining metabolites could be observed to form, while for $\gamma$-HBCDD two such metabolites were detected. Hydroxy-metabolites of both the $\beta$ diastereomer and $\gamma$-diastereomer were found.

The above described studies demonstrate that HBCDD is efficiently taken up (absorbed) by mammals and that $\beta$ - and $\gamma$-diastereomers are metabolised faster than $\alpha$-HBCDD.

\subsubsection{Evidence from measured levels in the environment}

Two studies investigating trophic transfer of HBCDD in freshwater are available. In Lake Ontario (CA) food web, a trophic magnification factor (TMF) based on ${ }^{815} \mathrm{~N}$ relationship of all collected data was estimated to be 6.3 (sum-HBCDD). For the comparison, TMF for p,p'DDE and for the sum of PCBs were 6.1 and 5.7 in the same study, respectively. The samples comprised of planctic invertebrates, Mysis, Diporeia, alewife, sculpin, smelt and trout. Lipid corrected factors for predator-prey bio- 
magnification were variable between feeding relationships and the highest for foragefish-zooplankton ranging from 3.5 for sculpin-Diporeia to 10.8 for smelt-Mysis for $\alpha$-HBCDD (Tomy et al., 2003, 2004a).

Law et al. (2006b) derived TMFs for Lake Winnipeg (CA) foodweb based on concentrations in six fish species, zooplankton, mussels, sediment and water. All three diastereomers were detected in all biotic samples. TMFs (excluding mussels) were 1.4, 1.3 and 2.2 for $\alpha$-, $\beta$ - and $\gamma$ HBCDD, respectively, according to the erratum of Law (2007). Lipid adjusted BMFs varied between 0.1 to 8.2 for $\alpha$-HBCDD, between 0.3 and 5 for $\beta$ - HBCDD and between 0.1 and 6.3 for $\gamma$-HBCDD.

Fjeld (2006a) found higher levels of HBCDD in brown trout (Salmo trutta trutta) compared to its prey species European smelt (Osmerus eperlanus) and vendance (Coregonus albula). The concentrations measured in 2005 were $466 \mu \mathrm{g} \mathrm{HBCDD} / \mathrm{kg}$ lwt $(8.8 \mu \mathrm{g} \mathrm{HBCDD} / \mathrm{kg} w w t), 374 \mu \mathrm{g}$ $\mathrm{HBCDD} / \mathrm{kg}$ lwt $(10.7 \mu \mathrm{g} \mathrm{HBCDD} / \mathrm{kg} w w t)$ and $729 \mu \mathrm{g} \mathrm{HBCDD} / \mathrm{kg}$ lwt (159 $\mu \mathrm{g} \mathrm{HBCDD/kg} \mathrm{wwt)} \mathrm{for} \mathrm{the} \mathrm{European} \mathrm{smelt,} \mathrm{vendace,} \mathrm{and} \mathrm{brown}$ trout, respectively.

Measured concentrations in water and in fish provide additional evidence that HBCDD accumulates in biota. The recent very few measurements of HBCDD in filtered water samples in European surface waters $(\mathrm{n}=14)$ show a range from 0.016 (or below detection limit) to $1.5 \mu \mathrm{g} / 1$ (point source recipient site, River Skerne)(European Commission, 2007a). For the comparison, concentrations measured in European freshwater fish muscle ( $\mathrm{n}=151)$ range from 0.005 (or below detection limit) to $9432 \mu \mathrm{g} / \mathrm{kg}$ ww with an arithmetic mean of $321 \pm 1130 \mu \mathrm{g} / \mathrm{kg}$ ww, median of $5.5 \mu \mathrm{g} / \mathrm{kg}$ ww and $90-\mathrm{P}$ of $834 \mu \mathrm{g} / \mathrm{kg}$ ww (European Commission, 2007a). The wholefish concentration in the field would be still higher based on the differences of HBCDD concentrations between non-edibles and edibles observed in the bioconcentration study of Drottar and Krueger (2000).

Using the median values of the measured data in fish and marine mammals in Western Europe, Baltic Sea, Western Scheldt and U.K., respectively, field ratios have been derived in the EU risk assessment of HBCDD (European Commission, 2007a) (Table 4.6). 
Table 4.6 Median concentrations of HBCDD in marine mammals and fish muscle collected from specific European regions. As for marine mammals the concentration in blubber is reported conventionally, the data have been converted to whole body concentrations assuming a 1/3 lipid/whole body ratio (European Commission, 2007a).

\begin{tabular}{|c|c|c|c|c|c|}
\hline \multirow[t]{2}{*}{ Region } & \multirow[t]{2}{*}{ Species } & \multirow[t]{2}{*}{$\mathbf{n}$} & \multirow[t]{2}{*}{ Median concentration } & \multicolumn{2}{|c|}{$\begin{array}{r}\text { Concentration } \\
\text { ratios } \\
\text { (marine } \\
\text { mammals/fish } \\
\text { muscle) }\end{array}$} \\
\hline & & & & $\begin{array}{l}\text { ww } \\
\text { bwl } \\
\text { ww }\end{array}$ & Iw/lw \\
\hline Western & Fish & 102 & $0.40 \mu \mathrm{g}$ HBCDD/ kg ww & & \\
\hline Europe & Marine mammals & $\begin{array}{l}100 \\
225 \\
225\end{array}$ & $\begin{array}{r}13 \mu \mathrm{g} \mathrm{HBCDD} / \mathrm{kg} \text { lw } \\
109 \mu \mathrm{g} \mathrm{HBCDD} / \mathrm{kg} \mathrm{ww} \\
368 \mu \mathrm{g} \mathrm{HBCDD} / \mathrm{kg} \text { lw }\end{array}$ & 272 & 28 \\
\hline Baltic Sea & Fish & $\begin{array}{l}42 \\
38\end{array}$ & $\begin{array}{r}0.31 \mu \mathrm{g} \mathrm{HBCDD} / \mathrm{kg} \text { ww } \\
11.5 \mu \mathrm{g} \mathrm{HBCDD} / \mathrm{kg} \mathrm{lw}\end{array}$ & & \\
\hline & Marine mammals & $\begin{array}{r}2 \\
\text { (representing } \\
20+30 \\
\text { individuals) }\end{array}$ & $19 \mu \mathrm{g} \mathrm{HBCDD} / \mathrm{kg} w w$ & 61 & 5.8 \\
\hline & & 2 & $67 \mu \mathrm{g} \mathrm{HBCDD} / \mathrm{kg}$ Iw & & \\
\hline Western- & Fish & 18 & $1.8 \mu \mathrm{g} \mathrm{HBCDD} / \mathrm{kg} \mathrm{ww}$ & & \\
\hline $\begin{array}{l}\text { Scheldt } \\
\text { (approx. } \\
\text { region) }\end{array}$ & Marine mammals & $\begin{array}{l}16 \\
19 \\
19\end{array}$ & $\begin{array}{r}107 \mu \mathrm{g} \mathrm{HBCDD} / \mathrm{kg} \text { Iw } \\
336 \mu \mathrm{g} \mathrm{HBCDD} / \mathrm{kg} \text { ww } \\
1144 \mu \mathrm{g} \mathrm{HBCDD} / \mathrm{kg} \text { Iw }\end{array}$ & 187 & 11 \\
\hline U.K. & Fish & $\begin{array}{r}300 \\
\text { (5 dietary } \\
\text { relevant } \\
\text { species; each } \\
\text { species } \\
\text { pooled data of } \\
60 \text { individuals) }\end{array}$ & $0.44 \mu \mathrm{g} \mathrm{HBCDD} / \mathrm{kg} \mathrm{ww}$ & 1859 & 44 \\
\hline & & 300 & $63 \mu \mathrm{g} \mathrm{HBCDD} / \mathrm{kg}$ lw & & \\
\hline & Harbour porpoise & $\begin{array}{l}34 \\
34\end{array}$ & $\begin{array}{l}818 \mu \mathrm{g} \mathrm{HBCDD} / \mathrm{kg} \mathrm{ww} \\
2780 \mu \mathrm{g} \mathrm{HBCDD} / \mathrm{kg} \text { Iw }\end{array}$ & & \\
\hline
\end{tabular}

The concentration ratios presented above may overestimate the actual field biomagnification as concentrations in fish muscle has been used for the calculations. Fish store more HBCDD in liver than in the muscle, whereas generally the whole fish is digested by mammals. Therefore European Commisson (2007a) calculated for the U.K. dataset a ratio based on fish whole weight, which was derived using liver to muscle relationsship (=123) of HBCDD concentrations in gadoid species bib and whiting from Janák et al. (2005a). This way, a liver concentration of 54 $\mu \mathrm{g} / \mathrm{kg}$ ww was calculated. Assuming that other parts have the same concentration as muscle $(0.44 \mu \mathrm{g} / \mathrm{kg} \mathrm{ww})$ and using the body part proportions of Lall (2005) for cod, a whole weight concentration of $3.2 \mu \mathrm{g} / \mathrm{kg}$ ww resulted. The ratio between harbour porpoise and its diet in U.K. was subsequently estimated to be 254 .

In addition, de Boer et al. (2002) have investigated accumulation in a North Sea food chain and a Western Sheldt food chain. The results also indicate that HBCDD is bioaccumulated.

$\alpha$-HBCDD is in general found at the highest concentrations of the three diastereomers in biota (fish, birds and mammals) (e.g., de Boer et al., 2002; Schlabach et al., 2002; Gerecke et al., 2003; Tomy et al., 
2004a; Janák et al., 2005a; Zegers et al., 2005; Law et al., 2006b; Ueno et al., 2006), although it is present in a concentration of $<10 \%$ of the commercial product and not a generally dominant species in abiotic samples (European Commission, 2007a). Several factors may lead -together or separately- to to the dominance of $\alpha$-HBCDD in biota. Firstly, the masstransfer limitations are lowest for $\alpha$-HBCDD of the three diastereomers based on its higher water solubility and lower logKow. These properties make it more readily available for uptake from environmental compartments and from gastrointestinal tract. Secondly, $\alpha$-HBCDD seems to have the lowest potential to be metabolised based on in vitro tests with mammals and fish (Zegers et al., 2005; Janák et al., 2005b). Additionally, bioisomerisation of $\gamma$-HBCDD and $\beta$-HBCDD to $\alpha$-HBCDD has been observed to occur in fish (Law et al., 2006a).

\subsubsection{Summary and conclusions}

Bioconcentration in fish was determined in the flow-through test of Veith et al. (1979) to be 18100 and in the standard flow-through test (OECD 305) of Drottar and Krueger (2000) to be 8 973-21940 depending on the exposure level and calculation method. No experimental data are available on the bioconcentration of specific diastereomers. The experimental $\operatorname{logKow}$ of the substance is 5.62 (MacGregor and Nixon, 1997).

The measured field data from various surveys compiled by European Commission (2007a) provide additional evidence on that HBCDD is bioaccumulated in biota in freshwater and marine environments and that the substance is biomagnified between trophic levels. According to more recent measured data, $\alpha-\mathrm{HBCDD}$ is the predominant diastereomer in biota. Based on two trophic transfer studies, $\alpha$-HBCDD would seem to biomagnify more than $\beta$ - and $\gamma$-HBCDD. Different accumulation of the three diastereomers followed in a 90-day repeated dose study with rats and the findings of an in vitro metabolism study with rat and harbour seal hepatic cells (Zegers et al., 2005) and in a similar study with fish hepatic cells (Janák et al., 2005b) support this observation.

For HBCDD the two available bioconcentration tests resulted BCFs in the range of 8973 - 21940 . The experimental logKow of the substance is 5.62. Additionally, HBCDD biomagnifies according to the available monitoring data in the aquatic food web. HBCDD is therefore concluded to clearly fulfil the POP screening criteria on bioaccumulation. 


\subsection{Potential for long-range environmental transport}

\subsubsection{Test results and model predictions}

HBCDD has a vapour pressure of $6.3 \times 10^{-5} \mathrm{~Pa}$ at $21{ }^{\circ} \mathrm{C}$ (Stenzel and Nixon, 1997), which indicates very low volatility. The substance is slightly volatile from aqueous surfaces based on the calculated Henry's law constant of $0.75 \mathrm{~Pa} \mathrm{~m} / \mathrm{mol}$ (water solubility of $66 \mu \mathrm{g} / \mathrm{l}$ for the sum of three diastereomers used for the calculation). Atmospheric degradation half-life has been estimated to be 76.8 hours (see section 4.1.1) and 51.2 hours (Wania, 2003).

Long-range atmospheric transport potential has been estimated by Wania (2003) and Palm et al. (2002) using different models (see Table 4.7).

Table 4.7 Estimated long-range atmospheric transport potential of HBCDD.

\begin{tabular}{lllll}
\hline & TaLP3 & ELPOS & ChemRange & Globo-POP \\
\hline $\begin{array}{l}\text { Travelling distance } \\
\text { (TR) (km in air) }\end{array}$ & $\begin{array}{l}\text { Characteristic } \\
\text { Travelling Distance } \\
\text { (CDT) (km in air) }\end{array}$ & $\begin{array}{l}\text { \% of earth's circum- } \\
\text { ference (TR) }\end{array}$ & ACP $^{* * *}{ }_{10}$ in \% \\
\hline HBCDD & $\begin{array}{l}760^{*} \\
2550^{* *}\end{array}$ & $784^{*}$ & $11^{*}$ & $2.28^{*}$ \\
\hline
\end{tabular}

$\mathrm{CDT}=$ distance at which $37 \%$ of initial mass in air is present

$\mathrm{TR}=$ distance, at which $5 \%$ of initial mass in air is present

Data from Wania (2003); Properties used: MP: $180^{\circ} \mathrm{C}$; VP: $2.6110^{-4} \mathrm{~Pa}\left(\right.$ at $25^{\circ} \mathrm{C}$ ); logKow 7.59 ; WS: $1.51^{*} 10^{-4} \mathrm{~mol} / \mathrm{m}^{3}$ (at $\left.25^{\circ} \mathrm{C}\right)$

**Palm et al. (2002)

${ }^{* \star \star A}$ Arctic contamination potential: The potential to contaminate Arctic after 10 years of steady emissions.

Wania (2003) conclude based on the properties of HBCDD, that its longrange transport is likely to be regulated by transport of aerosols.

Travel distances in air for HBCDD were also estimated with ELPOS 1.0.1 for this report using the properties in Table 3.1 and 3.2. Other program settings were the defaults as provided in the program (see Table 4.8). Characteristic travel distance in air is a distance at which the concentration has dropped to $37 \%$ of the concentration at the source. 
Table 4.8 Long-range atmospheric transport potential of HBCDD and some POPs estimated with ELPOS 1.0.1 (Beyer and Matthies, 2002).

\begin{tabular}{|c|c|c|}
\hline & $\begin{array}{l}\text { Characteristic travel } \\
\text { distance in air }(\mathrm{km}) \text {; } \\
\text { ELPOS 1.0.1 }\end{array}$ & Properties used \\
\hline $\begin{array}{l}\text { HBCDD (commercial } \\
\text { product) }\end{array}$ & 1525 & $\begin{array}{l}\text { MP: } 190^{\circ} \mathrm{C} \text {; VP: } 6.2 \mathrm{E} 10^{-5} \mathrm{~Pa} \text {; WS: } 66 \mu \mathrm{g} / \mathrm{l} \text {; } \\
\text { logKow: } 5.62 \text {; DT50air: } 3.2 \text { days; DT50 = } 6000 \\
\text { days in other compartments }\end{array}$ \\
\hline$\alpha-H B C D D$ & 1544 & $\begin{array}{l}\text { MP: } 179^{\circ} \mathrm{C} \text {; VP: } 6.2 \mathrm{E} 10^{-5} \mathrm{~Pa} \text {; WS: } 48.8 \mu \mathrm{g} / \mathrm{l} ; \\
\text { logKow: } 5.07 \text {; DT50air: } 3.2 \text { days; DT50 = } 6000 \\
\text { days in other compartments }\end{array}$ \\
\hline$\beta-H B C D D$ & 1570 & $\begin{array}{l}\text { MP: } 170{ }^{\circ} \mathrm{C} \text {; VP: } 6.2 \mathrm{E} 10^{-5} \mathrm{~Pa} \text {; WS: } 14.7 \mu \mathrm{g} / \mathrm{l} ; \\
\text { logKow: } 5.12 \text {; DT50air: } 3.2 \text { days; DT50 = } 6000 \\
\text { days in other compartments }\end{array}$ \\
\hline $\mathrm{Y}-\mathrm{HBCDD}$ & 1588 & $\begin{array}{l}\text { MP: } 207^{\circ} \mathrm{C} \text {; VP: } 6.2 \mathrm{E} 10^{-5} \mathrm{~Pa} \text {; WS: } 2.1 \mu \mathrm{g} / \mathrm{l} ; \\
\text { logKow: } 5.47 \text {; DT50air: } 3.2 \text { days; DT50 = } 6000 \\
\text { days in other compartments }\end{array}$ \\
\hline \multicolumn{3}{|l|}{$\begin{array}{l}\text { Persistent organic pollu- } \\
\text { tants }\end{array}$} \\
\hline $\begin{array}{l}\text { Pentabromodiphenyl ether } \\
\text { (commercial product) }\end{array}$ & 1809 & $\begin{array}{l}\text { MP }-3{ }^{\circ} \mathrm{C} \text {; VP: } 4.69 \mathrm{E} 10^{-5} \mathrm{~Pa} \text {; WS: } 13.3 \mu \mathrm{g} / \mathrm{l} \text {; } \\
\text { logKow: } 6.57 \text {; DT50air } 12.6 \text { days; (data from } \\
\text { European Commission, 2001). DT50 } 6000 \\
\text { days in other compartments }\end{array}$ \\
\hline PCB-47 & 31462 & Beyer and Matthies (2002) \\
\hline $\mathrm{Y}-\mathrm{HCH}$ & 7639 & \\
\hline pp'-DDE & 3431 & \\
\hline PCB-153 & 2495 & \\
\hline Dieldrin & 1123 & \\
\hline Aldrin & 104 & \\
\hline
\end{tabular}

For the comparison, Wania and Dugani (2003) have estimated the longrange transport potential of PBDEs using physical-chemical properties of several congeners. Characteristic travelling distance ranged from 1113 to $2483 \mathrm{~km}$ for a tetrabromo, 608 to $1349 \mathrm{~km}$ for a pentabromo, 525 to $854 \mathrm{~km}$ for a hexabromo, and 480 to $735 \mathrm{~km}$ for the decabromo congener.

The different models estimating long-range atmosperic trasport (LRAT) potential are sensitive to the input value of atmospheric half-life (DT50air). The half-life value is on its behalf very sensitive to the settings of OH-radical concentration in air in the model used for the estimation of the half-life. In addition, the LRAT-models are sensitive to the input value of logKow or other distribution coefficients. Differences between the estimates of Wania (2003) and estimates in Table 4.8 are probably mainly caused by the different values of DT50air and $\operatorname{logKow}$ used in each case. Based on the presented model estimates, the atmospheric long-range transport potential of HBCDD is approximately similar to the atmospheric long-range transport potential of the commercial pentabromodiphenyl ether, which was agreed to be a POP by the POPRC under the Stockholm Convention in 2006. The long-range atmospheric transport potential of HBCDD is also comparable and inside the range of estimated characteristic travel distances of POPs already included in the treaty (see Table 4.8). 


\subsubsection{Evidence from measured levels in the environment}

Ueno et al. (2006) have compared half-distances for HBCDD, polybrominated diphenylethers and POPs of the Stockholm Convention in the North Pacific based on skipjack tuna (Katsuwonus pelamis) monitoring (see Table 4.9). Analysed concentrations in muscle have been the basis for the estimates. One pooled sample of five specimen was analysed from each location.

Table 4.9 Calculated half-distances for HBCDD, PBDEs and POPs in the North Pacific based on skipjack tuna monitoring (compiled in Ueno et al., 2006).

\begin{tabular}{lrrr}
\hline Substance & Number of measured levels & Correlation coefficient $\left(\mathbf{r}^{2}\right)$ & Half-distance $\pm S E(\mathbf{k m})$ \\
\hline$\alpha-H C H$ & 5 & 0.83 & $-1700 \pm 480$ \\
$\alpha-H B C D D$ & 4 & 0.45 & $8500 \pm 6700$ \\
Y-HBCDD & 4 & 0.73 & $1600 \pm 680$ \\
BDE-99 & 5 & 0.87 & $1400 \pm 320$ \\
BDE-153 & 5 & 0.79 & $1200 \pm 380$ \\
$2378-T 4 C D F$ & 5 & 0.93 & $3200 \pm 530$ \\
$23478-P 5 C D F$ & 5 & 0.87 & $2100 \pm 470$ \\
SPCBS & 5 & 0.77 & $1500 \pm 480$ \\
p,p'-DDT & 5 & 0.91 & $950 \pm 170$ \\
\hline
\end{tabular}

Half-distance was in this study defined as the distance from the source (Japan), where the concentration in tuna muscle drops to $50 \%$ of the concentration at $/$ near the source. The authors have concluded based on their earlier analyses of other organohalogen compounds, that concentration in tuna muscle lipids reflects well the concentration of pollutants in water at the sampling site. It is noted, that this method cannot distinguish between long-range transport via air and water, although it can apparently exclude the impact of migration.

Tuna samples from offshore waters of various regions (Japan, Taiwan, Philippines, Indonesia, Seychelles, Brazil, Japan sea, East China sea, South China Sea, Indian Ocean and 3 North Pacific Ocean open sea sites) were analysed during the years 1997-2001 for several organohalogen compounds by the same research group (Ueno et al., 2006). In the samples of the northern hemisphere, the contribution of $\alpha$-HBCDD to the total HBCDD increased with increasing latitude. All the three main diastereomers were detected in the majority of the samples of the northern hemisphere, whereas only $\alpha$-HBCDD was detected in two of the three sourthern hemisphere sites (n.d. at Seychelles). The spatial distribution of the concentrations of HBCDD was highly correlated with the distribution of coplanar PCBs, chlordanes and PCDFs.

The authors commented, that the half-distance of HBCDD reflected one of the highest long-range transportabilities among the substances investigated. However, it must be noted, that for HBCDD, significance of the distance-to-concentration correlation was very low $\left(r^{2}=0.45 ; p=0.33\right)$ and standard errors of the estimates were rather high probably due to the low amount of sites included (four sites used as the basis of the regression). Nevertheless, the findings of the study of Ueno et al. (2006) can be 
taken as evidence of a high long-range transport potential for HBCDD, when the results are looked together with the results of other organohalogen compounds studied.

HBCDD is abundant in the majority of samples collected in remote areas and show a widespread occurrence. HBCDD has been detected in the atmosphere, sediments, deposition and biota in a variety of trophic levels in the Arctic region. Recent key data providing evidence of longrange transport of HBCDD are compiled in Table 4.10. There are no known point sources of HBCDD in these areas and it is very unlikely, that the small human populations of the most remote areas would release HBCDD at a level which would lead to the observed concentrations.

Knudsen et al. (2005) found a statistically significant, increasing temporal trend of HBCDD concentrations in eggs of marine bird populations of the Norwegian Arctic (see Figure 4.3).
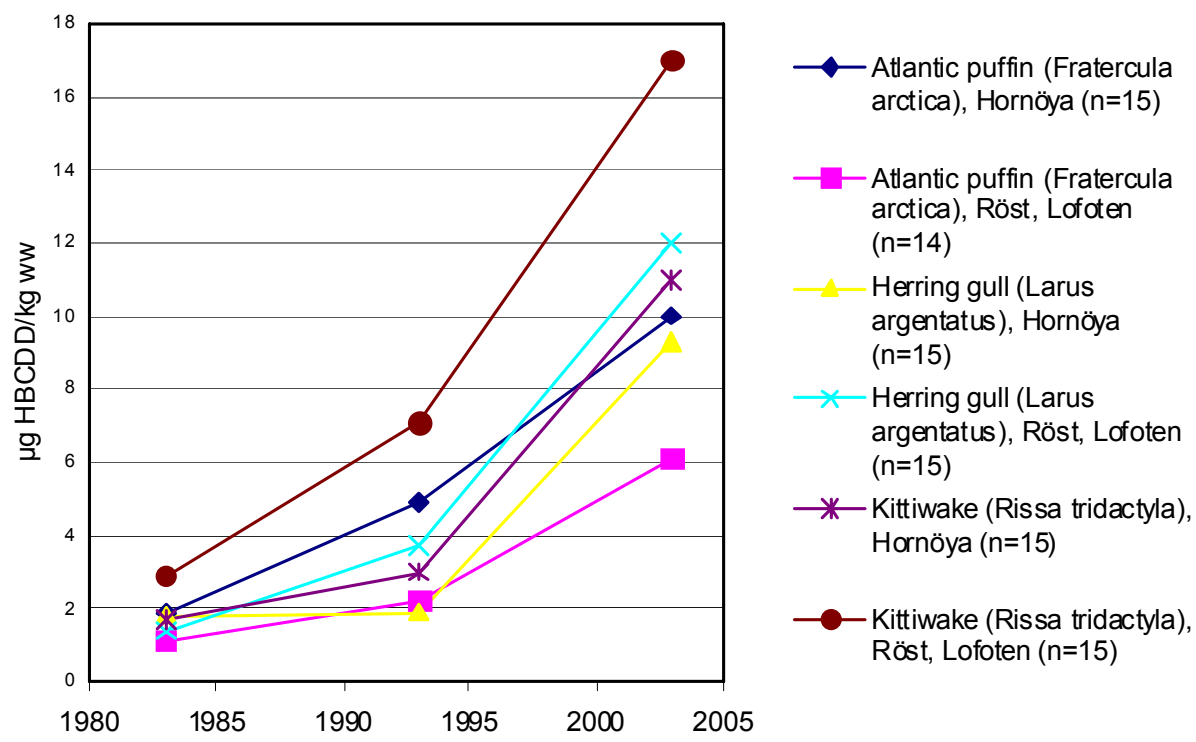
arctica), Hornöya $(n=15)$

- Atlantic puffin (Fratercula arctica), Röst, Lofoten $(n=14)$ Herring gull (Larus argentatus), Hornöya $(n=15)$

$\longrightarrow$ Herring gull (Larus argentatus), Röst, Lofoten $(n=15)$

$\rightarrow$ Kittiwake (Rissa tridactyla), Hornöya $(n=15)$

- Kittiwake (Rissa tridactyla), Röst, Lofoten $(n=15)$

Figure 4.3 Temporal trend in marine bird eggs in two remote locations in the Norwegian Arctic (data of Knudsen et al., 2005). 
Table 4.10 Measured environmental concentrations of HBCDD in the most remote areas.

\begin{tabular}{|c|c|c|c|}
\hline Species, sample typel & Location; sampling yeasr & Concentration & Reference \\
\hline \multirow[t]{3}{*}{$\underline{\text { Air }}$} & $\begin{array}{l}\text { Ammarnäs, northern } \\
\text { Sweden }\end{array}$ & $\begin{array}{l}5.7 \mathrm{pg} \mathrm{HBCDD} / \mathrm{m}^{3} \text { in particulate phase } \\
0.2 \mathrm{pg} \mathrm{HBCDD} / \mathrm{m}^{3} \text { in vapour phase }\end{array}$ & $\begin{array}{l}\text { Bergander et } \\
\text { al. (1995) }\end{array}$ \\
\hline & $\begin{array}{l}\text { Pallas, Finland } \\
\text { (arctic area) }\end{array}$ & $\begin{array}{l}0.003 \mathrm{ng} \mathrm{HBCDD} / \mathrm{m}^{3} \text { (autumn 2000), } \\
\text { total conc. }\end{array}$ & $\begin{array}{l}\text { Sternbeck et } \\
\text { al. (2001) }\end{array}$ \\
\hline & & $\begin{array}{l}0.002 \mathrm{ng} \mathrm{HBCDD} / \mathrm{m}^{3} \text { (winter 2001), total } \\
\text { conc. }\end{array}$ & \\
\hline \multirow[t]{2}{*}{ Deposition } & $\begin{array}{l}\text { Pallas, Finland (arctic } \\
\text { area) }\end{array}$ & $\begin{array}{l}13 \mathrm{ng} / \mathrm{m}^{2} \mathrm{~d} \text {, precipitation } 21 \mathrm{~mm} \text { (au- } \\
\text { tumn 2000) }\end{array}$ & $\begin{array}{l}\text { Sternbeck et } \\
\text { al. (2001) }\end{array}$ \\
\hline & & $\begin{array}{l}5.1 \mathrm{ng} / \mathrm{m}^{2} \mathrm{~d} \text {. precipitation } 4 \mathrm{~mm} \text { (winter } \\
2001 \text { ) }\end{array}$ & \\
\hline Sediment & $\begin{array}{l}\text { Ellasjøen, Bjørnøya, } \\
\text { Svalbard, Norway }{ }^{1)}\end{array}$ & $\begin{array}{l}3.8 \mathrm{ng} \text { y-HBCDD /g dw in a sediment } \\
\text { layer corresponding years } 1973-1987 . \\
\alpha-\text { and } \beta-H B C D D \text { were below LOD. All } \\
\text { diastereomer concentrations in top } \\
\text { layer (1987-2001) and earlier than } 1973 \\
\text { were < LOD. }\end{array}$ & $\begin{array}{l}\text { Christensen } \\
\text { et al. (2004) }\end{array}$ \\
\hline \multicolumn{4}{|l|}{ Birds } \\
\hline $\begin{array}{l}\text { Glaucous gull } \\
\text { (Larus hyperbo- } \\
\text { reus), eggs }\end{array}$ & $\begin{array}{l}\text { Bjørnøya, Svalbard, } \\
\text { Norway, year } 1997^{1)}\end{array}$ & $\begin{array}{l}2.3 \pm 0.2 \mu \mathrm{g} \mathrm{HBCDD} / \mathrm{kg} w w(\text { mean } \pm S D) \\
\mathrm{n}=3\end{array}$ & $\begin{array}{l}\text { Knudsen et } \\
\text { al. (2005) }\end{array}$ \\
\hline $\begin{array}{l}\text { Glaucous gull } \\
\text { (Larus hyperbo- } \\
\text { reus), eggs }\end{array}$ & $\begin{array}{l}\text { Bjørnøya, Svalbard, } \\
\text { Norway, year } 2002^{1)}\end{array}$ & $\begin{array}{l}12 \pm 3.3 \mu \mathrm{g} \mathrm{HBCDD} / \mathrm{kg} \text { ww (mean } \pm \mathrm{SD}) \\
\mathrm{n}=4\end{array}$ & -"- \\
\hline $\begin{array}{l}\text { Glaucous gull } \\
\text { (Larus hyperbo- } \\
\text { reus), eggs }\end{array}$ & $\begin{array}{l}\text { Bjørnøya, Svalbard, } \\
\text { Norway, year 2003? }\end{array}$ & $\begin{array}{l}13 \pm 6.42 \mu \mathrm{g} \mathrm{HBCDD} / \mathrm{kg} w w(\text { mean } \pm S D) \\
\mathrm{n}=10\end{array}$ & $\begin{array}{l}\text { Verreault et } \\
\text { al. }(2004)\end{array}$ \\
\hline $\begin{array}{l}\text { Glaucous gull } \\
\text { (Larus hyperbo- } \\
\text { reus), blood plas- } \\
\text { ma, males }\end{array}$ & $\begin{array}{l}\text { Bjørnøya, Svalbard, } \\
\text { Norway, year 2003? }\end{array}$ & $\begin{array}{l}0.51 \pm 0.13 \mu \mathrm{g} \mathrm{HBCDD} / \mathrm{kg} \mathrm{ww} \\
(\text { mean } \pm \mathrm{SD}), \mathrm{n}=20\end{array}$ & -"- \\
\hline $\begin{array}{l}\text { Glaucous gull } \\
\text { (Larus hyperbo- } \\
\text { reus), blood plas- } \\
\text { ma, females }\end{array}$ & $\begin{array}{l}\text { Bjørnøya, Svalbard, } \\
\text { Norway, year 2003? }{ }^{1)}\end{array}$ & $\begin{array}{l}0.70 \pm 0.16 \mu g \mathrm{HBCDD} / \mathrm{kg} \mathrm{ww} \\
(\text { mean } \pm \mathrm{SD}), \mathrm{n}=20\end{array}$ & -"- \\
\hline $\begin{array}{l}\text { Glaucous gull } \\
\text { (Larus hyperbo- } \\
\text { reus), yolk sack }\end{array}$ & $\begin{array}{l}\text { Bjørnøya, Svalbard, } \\
\text { Norway, year } 2006^{1)}\end{array}$ & $\begin{array}{l}19.8 \pm 2.2 \mu \mathrm{g} \mathrm{HBCDD} / \mathrm{kg} \mathrm{ww} \\
(\text { mean } \pm \mathrm{SD}), \mathrm{n}=31 ; 100 \%>\mathrm{LOQ}\end{array}$ & $\begin{array}{l}\text { Verreault et } \\
\text { al. (2007) }\end{array}$ \\
\hline $\begin{array}{l}\text { Glaucous gull } \\
\text { (Larus hyperbo- } \\
\text { reus), blood plas- } \\
\text { ma, males }\end{array}$ & $\begin{array}{l}\text { Bjørnøya, Svalbard, } \\
\text { Norway, year } 2006^{1)}\end{array}$ & $\begin{array}{l}1.73 \pm 0.37 \mu \mathrm{H} \mathrm{HBCDD} / \mathrm{kg} \mathrm{ww} \\
(\text { mean } \pm \mathrm{SD}), \mathrm{n}=19 ; 65 \%>\mathrm{LOQ}\end{array}$ & -"- \\
\hline $\begin{array}{l}\text { Glaucous gull } \\
\text { (Larus hyperbo- } \\
\text { reus), blood plas- } \\
\text { ma, females }\end{array}$ & $\begin{array}{l}\text { Bjørnøya, Svalbard, } \\
\text { Norway, year } 2006^{1)}\end{array}$ & $\begin{array}{l}2.07 \pm 0.36 \mu \mathrm{g} \mathrm{HBCDD} / \mathrm{kg} \mathrm{ww} \\
(\text { mean } \pm \mathrm{SD}), \mathrm{n}=30 ; 60 \%>\mathrm{LOQ}\end{array}$ & -"- \\
\hline $\begin{array}{l}\text { Glaucous gull } \\
\text { (Larus hyperbo- } \\
\text { reus), liver }\end{array}$ & $\begin{array}{l}\text { Bjørnøya, Svalbard, } \\
\text { Norway, years 2003- } \\
2005^{1)}\end{array}$ & $\begin{array}{l}3026 \pm 4322 \mu \mathrm{g} \mathrm{a}-\mathrm{HBCDD} / \mathrm{kg} \text { lw } \\
(\text { mean } \pm \mathrm{SD}), \mathrm{n}=21 \text { (all > LOQ) }\end{array}$ & $\begin{array}{l}\text { Knudsen et } \\
\text { al. (2007) }\end{array}$ \\
\hline $\begin{array}{l}\text { Glaucous gull } \\
\text { (Larus hyperbo- } \\
\text { reus), brain }\end{array}$ & $\begin{array}{l}\text { Bjørnøya, Svalbard, } \\
\text { Norway }{ }^{1)} \text { years 2003- } \\
2005^{1)}\end{array}$ & $\begin{array}{l}98.9 \pm 136 \mu \mathrm{g} \alpha-\mathrm{HBCDD} / \mathrm{kg} \mathrm{lw} \\
(\text { mean } \pm \mathrm{SD}), \mathrm{n}=21 \text { (all > LOQ) }\end{array}$ & -"- \\
\hline $\begin{array}{l}\text { Great black-tailed } \\
\text { gulls (Larus grassi- } \\
\text { rostris), liver }\end{array}$ & $\begin{array}{l}\text { Bjørnøya Svalbard, } \\
\text { Norway, years 2003- } \\
2005^{1)}\end{array}$ & $\begin{array}{l}3699 \text { and } 1881 \mu \mathrm{g} \alpha-\mathrm{HBCDD} / \mathrm{kg} \mathrm{Iw} \\
(\mathrm{mean} \pm \mathrm{SD}), \mathrm{n}=2\end{array}$ & -"- \\
\hline $\begin{array}{l}\text { Great black-tailed } \\
\text { gulls (Larus crassi- } \\
\text { rostris), brain }\end{array}$ & $\begin{array}{l}\text { Bjørnøya, Svalbard, } \\
\text { Norway }{ }^{1)}\end{array}$ & $\begin{array}{l}44.8 \text { and } 44.7 \mu g \alpha-H B C D D / k g ~ I w \\
(m e a n \pm S D), n=2\end{array}$ & -"- \\
\hline
\end{tabular}




\begin{tabular}{|c|c|c|c|}
\hline Species, sample typel & Location; sampling yeasr & Concentration & Reference \\
\hline $\begin{array}{l}\text { Northern fulmar } \\
\text { (Fulmarus glacialis), } \\
\text { liver }\end{array}$ & $\begin{array}{l}\text { Bjørnøya, Svalbard, } \\
\text { Norway }{ }^{1}\end{array}$ & $\begin{array}{l}0.65 \pm 0.7 \mu \mathrm{g} \mathrm{HBCDD} / \mathrm{kg} \mathrm{ww} \\
\text { (mean } \pm \mathrm{SD}), \mathrm{n}=15 \text { ( } 14 \text { samples beyond } \\
\mathrm{DL} \text { ) }\end{array}$ & $\begin{array}{l}\text { Gabrielsen et } \\
\text { al. (2005) }\end{array}$ \\
\hline $\begin{array}{l}\text { Peregrine falcon } \\
\text { (Falco peregrinus), } \\
\text { eggs }\end{array}$ & $\begin{array}{l}\text { Southern Greenland, } \\
\text { Denmark } \\
\text { Years 1986-2003 }\end{array}$ & $\begin{array}{l}5.3,(0.08-5.3) \mu \mathrm{g} \mathrm{HBCDD} / \mathrm{kg} \mathrm{ww} \\
\text { (median, }(\min -\mathrm{max})), \mathrm{n}=33 \text { (20 sam- } \\
\text { ples beyond } \mathrm{DL})\end{array}$ & $\begin{array}{l}\text { Sørensen et } \\
\text { al. }(2004)\end{array}$ \\
\hline $\begin{array}{l}\text { Brünnich's guillemot } \\
\text { (Uria lomvia), yolk } \\
\text { sack }\end{array}$ & $\begin{array}{l}\text { Kongsfjorden, Svalbard, } \\
\text { Norway; year } 2002^{2)}\end{array}$ & $\begin{array}{l}35.4 \pm 15.7 \mu \mathrm{g} \mathrm{HBCDD} / \mathrm{kg} \mathrm{lw} \\
\text { (mean } \pm \mathrm{SD}), \mathrm{n}=9\end{array}$ & $\begin{array}{l}\text { Murvoll et al. } \\
(2007)\end{array}$ \\
\hline $\begin{array}{l}\text { Common eider } \\
\text { (Somateria mollis- } \\
\text { sima), yolk sack }\end{array}$ & $\begin{array}{l}\text { Kongsfjorden, Svalbard, } \\
\text { Norway; year } 2002^{2)}\end{array}$ & $\begin{array}{l}6.23 \mu \mathrm{g} \mathrm{HBCDD} / \mathrm{kg} \text { lw (detected in one } \\
\text { out of } 14 \text { samples) }\end{array}$ & $\begin{array}{l}\text { Murvoll et al. } \\
(2007)\end{array}$ \\
\hline \multirow[t]{2}{*}{$\begin{array}{l}\text { Arctic tern (Sterna } \\
\text { paradiaea), eggs }\end{array}$} & $\begin{array}{l}\text { Svalbard, Norway }{ }^{2)} \text {; } \\
2003\end{array}$ & $\begin{array}{l}4.62 \pm 1.44 \mu \mathrm{g} \mathrm{HBCDD} / \mathrm{kg} \mathrm{lw} \\
(\text { mean } \pm \mathrm{SD}), \mathrm{n}=10\end{array}$ & $\begin{array}{l}\text { Jenssen et al. } \\
(2007)\end{array}$ \\
\hline & & Figure 4.3 contains additional data & \\
\hline \multicolumn{4}{|l|}{ Invertebrates } \\
\hline Gammarus wilkitzkii & $\begin{array}{l}\text { North Atlantic, Svalbard } \\
\text { area, Norway }{ }^{2)} ; 2003\end{array}$ & Not detected & $\begin{array}{l}\text { Sørmo et al. } \\
(2006)\end{array}$ \\
\hline \multicolumn{4}{|l|}{ Fish } \\
\hline $\begin{array}{l}\text { Polar cod (Boreo- } \\
\text { gadus saida); whole } \\
\text { fish }\end{array}$ & $\begin{array}{l}\text { Svalbard, Norway }{ }^{2)} \text {; } \\
2003\end{array}$ & $\begin{array}{l}1.73 \mu \mathrm{g} \mathrm{HBCDD} / \mathrm{kg} \text { Iw (median); min- } \\
\max : 1.38-2.87, \mathrm{n}=7\end{array}$ & $\begin{array}{l}\text { Sørmo et al. } \\
(2006)\end{array}$ \\
\hline $\begin{array}{l}\text { Polar cod (Boreo- } \\
\text { gadus saida); whole } \\
\text { fish }\end{array}$ & $\begin{array}{l}\text { Bjørnøya, Svalbard }{ }^{1)} \text {, } \\
\text { Norway; } 2003\end{array}$ & $\begin{array}{l}11.7 \pm 7.2 \mu \mathrm{g} \mathrm{HBCDD} / \mathrm{kg} \text { lw (mean } \pm S D) \\
\mathrm{n}=6\end{array}$ & $\begin{array}{l}\text { Jenssen et al. } \\
(2007)\end{array}$ \\
\hline \multicolumn{4}{|l|}{ Mammals } \\
\hline $\begin{array}{l}\text { Polar bear (Ursus } \\
\text { maritimus), adipose } \\
\text { tissue (females) }\end{array}$ & $\begin{array}{l}\text { Svalbard, Norway }{ }^{2)} \\
2002\end{array}$ & $\begin{array}{l}26 \pm 9.0 \mu \mathrm{g} H B C D D / k g ~ w w(m e a n \pm S D) \\
\text { min-max: } 9.7-45, n=15\end{array}$ & $\begin{array}{l}\text { Gabrielsen et } \\
\text { al. (2004) }\end{array}$ \\
\hline $\begin{array}{l}\text { Polar bear (Ursus } \\
\text { maritimus), adipose } \\
\text { tissue (males) }\end{array}$ & $\begin{array}{l}\text { Svalbard, Norway }{ }^{2)} \\
2002-2003\end{array}$ & $\begin{array}{l}12.6 \mu \mathrm{g} \mathrm{HBCDD} / \mathrm{kg} \text { Iw (median); min- } \\
\max : 5.31-16.51, \mathrm{n}=4\end{array}$ & $\begin{array}{l}\text { Sørmo et al. } \\
(2006)\end{array}$ \\
\hline $\begin{array}{l}\text { Harbor seal (Phoca } \\
\text { vitulina), blubber }\end{array}$ & $\begin{array}{l}\text { Svalbard, Norway') } \\
2003\end{array}$ & $\begin{array}{l}3.66 \pm 1.54 \mu \mathrm{g} \mathrm{HBCDD} / \mathrm{kg} \mathrm{lw} \\
\text { (mean } \pm \mathrm{SD}), \mathrm{n}=5\end{array}$ & $\begin{array}{l}\text { Jenssen et al. } \\
(2007)\end{array}$ \\
\hline $\begin{array}{l}\text { Ringed seal ( } P \text { usa } \\
\text { hispida), blubber }\end{array}$ & $\begin{array}{l}\text { Svalbard, Norway }{ }^{2)} \\
2003\end{array}$ & $\begin{array}{l}16.96 \mu \mathrm{g} \mathrm{HBCDD} / \mathrm{kg} \text { lw (median); min- } \\
\text { max: } 14.6-34.5, \mathrm{n}=6\end{array}$ & $\begin{array}{l}\text { Sørmo et al. } \\
(2006)\end{array}$ \\
\hline
\end{tabular}

1. Bjørnøya, Svalbard, Norway, is the southernmost island of the group of islands of Svalbard (see below)

2. Svalbard, Norway, is an archipelago in the Arctic Ocean in the midway from Norway to the north pole.

Despite its low volatility and very high adsorption potential, HBCDD has been found in air samples at concentrations above detection limits. In addition to values represented in Table 4.10, HBCDD was measured at European background locations (Hoburgen, Aspvreten and Rörvik, Sweden) at concentrations of 0.005 to $0.28 \mathrm{ng} \mathrm{HBCDD} / \mathrm{m}^{3}$ (one measured value of 6 was below detection limit of $0.005 \mathrm{ng} / \mathrm{m}^{3}$ ) (Bergander et al., 1995; Sternbeck et al., 2001). Levels in air close to point sources or areal sources varied between 0.01 to $1070 \mathrm{ng} \mathrm{HBCDD} / \mathrm{m}^{3}$ ( 5 sites, $\mathrm{n}=8$ in total; total conc.) (Sternbeck et al., 2001; Waindzioch, 2000). 


\subsubsection{Summary and conclusions}

HBCDD is detected in most of the samples analysed in the recent years in the most remote sites of the Arctic region. HBCDD has been found in the Arctic in several bird populations, air, deposition, sediment, fish and mammals. Additionally, an increasing temporal trend in some marine bird populations in the Norwegian Arctic has been observed. Despite the still rather small dataset from remote areas, the findings indicate that HBCDD enters these areas via long-range transport.

Atmospheric degradation half-life of vapour phase HBCDD varies on both sides of 2 days depending on the model settings. Characteristic travel distance (CTD) in air was estimated to be ca. $1500 \mathrm{~km}$ using ELPOS model. This is approximately in the range of CTDs estimated for pentabromodiphenyl ether and other POPs. The half-distances calculated by Ueno et al. (2006) based on skipjack tuna monitoring in the North Atlantic seem also to suggest a high long-range environmental transport potential.

HBCDD fulfils the numerical POP criteria for half-life in air. Based on evidence from modelling and measured data from remote areas, HBCDD is subject to long-range environmental transport. These data indicate, that the long-range transport potential of HBCDD would be roughly similar as the long-range transport potential of the middle sized PCBs and PBDEs. HBCDD is concluded to fulfil the POP screening criteria for long-range transport potential.

\subsection{Adverse effects}

\subsubsection{Ecotoxicity}

Ecotoxicity testing in aqueous media is complicated by the very low water solubility and high adsorption potential of HBCDD. Ecotoxicity of specific diastereomers has not been tested and although most studies report the diastereomer shares of the test material, concentrations of them in the test medium have been reported only in the studies of Desjardins et al. $(2004,2005)$ and Aufderheide et al. (2003).

The results of ecotoxicity tests, which have been considered reliable by European Commission (2007a), are presented in Table 4.11. 
Table 4.11 Acute and chronic ecotoxicity data, which are considered reliable according to European Commission (2007a)

\begin{tabular}{|c|c|c|c|}
\hline Compartment/Species & Method & Results\# & Remark and reference \\
\hline \multicolumn{4}{|l|}{ AQUATIC COMPARTMENT } \\
\hline \multicolumn{4}{|l|}{ FISH } \\
\hline Onchorhyncus mykiss & $\begin{array}{l}\text { OECD } 203 \text { and } \\
\text { TSCA 40/797/1400, and ASTM } \\
\text { Standard E729-88a }\end{array}$ & $\begin{array}{l}\text { No mortalities or other } \\
\text { effects around } 2.5 \mu \mathrm{g} / \mathrm{l} \text {. }\end{array}$ & Graves and Swigert (1997a) \\
\hline Onchorhyncus mykiss & $\begin{array}{l}\text { Flow-through } \\
\text { OECD } 210 \text { and OPPTS } \\
850.1400\end{array}$ & $\begin{array}{l}\text { NOEC: Hatching suc- } \\
\text { cess } \geq 3.7 \mu \mathrm{g} / \mathrm{l} \\
\text { Swim-up } \geq 3.7 \mu \mathrm{g} / \mathrm{l} \\
\text { Larvae and fry survival } \\
\geq 3.7 \mu \mathrm{g} / \mathrm{l} \\
\text { Growth } \geq 3.7 \mu \mathrm{g} / \mathrm{l}\end{array}$ & Drottar et al. (2001) \\
\hline \multicolumn{4}{|l|}{ INVERTEBRATES } \\
\hline Daphnia magna & $\begin{array}{l}\text { OECD 202. Static immobilisa- } \\
\text { tion test, and } \\
\text { TSCA 40/797/1300, and ASTM } \\
\text { Standard E729-88a }\end{array}$ & $48 \mathrm{~h} \mathrm{EC}_{50}>3.2 \mu \mathrm{g} / \mathrm{l}$ & Graves and Swigert (1997b) \\
\hline Daphnia magna & $\begin{array}{l}\text { TSCA, OECD } \\
\text { Flow through } 21 \text { day test. }\end{array}$ & $\begin{array}{l}\text { NOEC } 3.1 \mu \mathrm{g} / \mathrm{l} \\
\text { LOEC length } 5.6 \mu \mathrm{g} / \mathrm{l}\end{array}$ & Drottar and Krueger (1998) \\
\hline \multicolumn{4}{|l|}{ ALGAE } \\
\hline Selenastrum capricornutum & $\begin{array}{l}\text { OECD } 201 \text { and } \\
\text { TSCA40/797/1050 }\end{array}$ & $96 \mathrm{~h} \mathrm{EC}_{50}>2.5 \mu \mathrm{g} / \mathrm{l}$ & Roberts and Swigert (1997) \\
\hline Skeletonema costatum & $\begin{array}{l}\text { Marine algal bioassay method, } \\
\text { different marine growth media }\end{array}$ & $\begin{array}{l}72 \mathrm{~h} \mathrm{EC}_{50}= \\
9 \mu \mathrm{g} / \mathrm{l} \text { (lowest value) }\end{array}$ & $\begin{array}{l}\text { Walsh et al. (1987) } \\
\text { Not according to guidelines, } \\
\text { results only used as suppor- } \\
\text { tive }\end{array}$ \\
\hline Thallassiosira pseudonana & & $\begin{array}{l}72 \mathrm{~h} \mathrm{EC}_{50}= \\
40 \mu \mathrm{g} / \mathrm{l} \text { (lowest value) }\end{array}$ & \\
\hline Chlorella sp. & & $\begin{array}{l}\text { 96h } \mathrm{EC}_{50}>\text { water solubi- } \\
\text { lity }\end{array}$ & \\
\hline Skeletonema costatum & $\begin{array}{l}\text { OECD 201, ISO 10253:1995 } \\
\text { and EU Directive 92/69/EEC - } \\
\text { Method C.3. One test concen- } \\
\text { tration at the limit of respective } \\
\text { water solubilites of each di- } \\
\text { astereomer. }\end{array}$ & $\begin{array}{l}\mathrm{NOEC}<40.6 \mu \mathrm{g} / \mathrm{l} \\
\mathrm{EC}_{50}>40.6\end{array}$ & Desjardins et al. (2004) \\
\hline Skeletonema costatum & $\begin{array}{l}\text { OECD 201. EC50 obtained from } \\
\text { a limit test with one test concen- } \\
\text { tration }(54.5 \mu \mathrm{g} / \mathrm{l}) \text { at the limit of } \\
\text { respective water solubilites of } \\
\text { each diastereomer. }\end{array}$ & $\begin{array}{l}\mathrm{NOEC}>10 \mu \mathrm{g} / \mathrm{l} \\
\mathrm{EC}_{50}=52 \mu \mathrm{g} / \mathrm{l}\end{array}$ & Desjardins et al. (2005) \\
\hline \multicolumn{4}{|c|}{ SEWAGE TREATMENT PLANT, MICRO-ORGANISMS } \\
\hline Acivated sludge & $\begin{array}{l}\text { Respiration inhibition } \\
\text { OECD } 209\end{array}$ & $\mathrm{EC}_{50}=15 \mathrm{mg} / \mathrm{l}$ & $\begin{array}{l}\text { Limit test with one test } \\
\text { concentration, } \mathrm{EC}_{50} \text { is an } \\
\text { estimated value. }\end{array}$ \\
\hline & & & Schaefer and Siddiqui (2003) \\
\hline \multicolumn{4}{|l|}{ SEDIMENT COMPARTMENT } \\
\hline INVERTEBRATES & & & \\
\hline $\begin{array}{l}\text { Hyalella azteca } \\
\text { (Amphipod) }\end{array}$ & $\begin{array}{l}\text { Sediment toxicity test } 28 \text {-day } \\
\text { exposure period under flow- } \\
\text { through conditions. }\end{array}$ & $\begin{array}{l}\text { LOEC }>1000 \mathrm{mg} / \mathrm{kg} \mathrm{dw} \\
\text { of sediment } \\
\text { NOEC } 1000 \mathrm{mg} / \mathrm{kg} \mathrm{dw} \text { of } \\
\text { sediment. }\end{array}$ & Thomas et al. (2003b) \\
\hline $\begin{array}{l}\text { Lumbriculus variegatus } \\
\text { (Worm) }\end{array}$ & 28-day sediment bioassay & $\begin{array}{l}\text { LOEC }=28.7 \mathrm{mg} / \mathrm{kg} \mathrm{dw} \\
\text { NOEC }=3.1 \mathrm{mg} / \mathrm{kg} \mathrm{dw} \\
\text { Normalized: }\end{array}$ & Oetken et al. (2001) \\
\hline
\end{tabular}




\begin{tabular}{|c|c|c|c|}
\hline Compartment/Species & Method & Results\# & Remark and reference \\
\hline $\begin{array}{l}\text { Chironomus riparius (Mosqui- } \\
\text { to) }\end{array}$ & $\begin{array}{l}\text { 28-day sediment bioassay } \\
\text { Egg production of } \mathrm{F} \text { generation }\end{array}$ & $\begin{array}{l}\text { NOEC }=8.61 \mathrm{mg} / \mathrm{kg} \mathrm{dw} \\
\text { LOEC }=159 \mathrm{mg} / \mathrm{kg} \mathrm{dw} \\
\text { NOEC }=13.6 \mathrm{mg} / \mathrm{kg} \mathrm{dw} \\
\text { Normalized: } \\
\text { NOEC }=37.8 \mathrm{mg} / \mathrm{kg} \mathrm{dw}\end{array}$ & Oetken et al. (2001) \\
\hline $\begin{array}{l}\text { TERRESTRIAL COMPARTMENT } \\
\text { PLANTS }\end{array}$ & & & \\
\hline $\begin{array}{l}\text { Plants: corn (Zea mays), } \\
\text { cucumber (Cucumis sativa), } \\
\text { onion (Allium cepa), ryegrass, } \\
\text { (Lolium perenne), soybean } \\
\text { (Glycine max), and tomato } \\
\text { (Lycopersicon esculentum) }\end{array}$ & $\begin{array}{l}\text { Seedling emergence, suvival, } \\
\text { height } \\
21 \text { days } \\
\text { OECD } 308 \text { (proposal for revisi- } \\
\text { on), } 850.4100 \text { and } 850.4225 \\
\text { (public drafts) }\end{array}$ & $\begin{array}{l}\text { NOEC }>5000 \mathrm{mg} / \mathrm{kg} \text { dry } \\
\text { soil }\end{array}$ & Porch et al. (2002) \\
\hline \multicolumn{4}{|l|}{ INVERTEBRATES } \\
\hline \multirow[t]{2}{*}{$\begin{array}{l}\text { Eisenia fetida } \\
\text { (Earthworm) }\end{array}$} & $\begin{array}{l}\text { Survival and reproduction, } 56 \\
\text { days }\end{array}$ & $\begin{array}{l}\text { NOEC } 128 \mathrm{mg} / \mathrm{kg} \text { dry } \\
\text { soil }\end{array}$ & Aufderheide et al. (2003) \\
\hline & $\begin{array}{l}\text { OECD prosal and } 207 \text { and } \\
\text { OPPTS } 850.6200\end{array}$ & $\begin{array}{l}\text { Normalized: } \\
\text { NOEC } 59 \text { mg/kg dry soil } \\
\text { (EC } 5771 \mathrm{mg} / \mathrm{kg} \text { dry soil) }\end{array}$ & \\
\hline
\end{tabular}

Based on the results from the long-term study of Dottar and Kruger (1998) with Dapnia magna and from the algae toxicity test of Desjardins (2005) with marine algae Skeletonema costatum, HBCDD is very toxic to aquatic organisms. HBCDD also causes adverse effects to sediment organisms at exposure level relevant for the environment based on the effects in the long-term test with Lumbriculus variegatus (Oetken et al., 2001).

It is noted, that both (unbounded) test results with fish and the acute daphnia test have been obtained using test concentrations up to the approximate limit of the apparent water solubility of HBCDD, which is close to the water solubility of $\gamma$-HBCDD and hence lower than the sum water solubility of the three main diastereomers of the commercial HBCDD.

\subsubsection{Toxicity}

Main findings from laboratory studies with mammals are that HBCDD causes effects in liver, thyroid gland and thyroid hormone homeostasis. It is noted, that only very few repeated oral dose studies (van der Ven et al., 2006; Eriksson et al., 2006) administered HBCDD in dissolved form but a HBCDD suspension was employed in most in vivo studies.

Three 28 day and two 90-day repeated dose studies with rats using oral administration are available. Liver weight increase was observed in females and males in the studies of Chengelis $(1997,2001)$ and Zeller and Kirsch $(1969,1970)$, whereas van der Ven et al. (2006) observed liver weight increase only in females. A NOAEL/BMD-L of 22.9 $\mathrm{mg} / \mathrm{kg} /$ day for liver weight increase could be derived from the study of van der Ven et al. (2006). In addition a BMD-L of $4 \mathrm{mg} / \mathrm{kg} / \mathrm{day}$ for he- 
patic T4-conjugation was derived for females, whereas an uncertain response was observed in males. Hepatic CYP2B-activity (PROD) was only induced in males (from $10 \mathrm{mg} / \mathrm{kg} / \mathrm{day}$ ), whereas mRNA and protein for CYP2B was increased also in females. Hepatic CYP3A4-induction (LBD) was only observed in females (from $10 \mathrm{mg} / \mathrm{kg} /$ day). T4 concentration in serum was also decreased in the study and both T4 and THT -concentrations were decreased in the study of Chengelis (2001).

Thyroid weight increase BMD-L of $2.2 \mathrm{mg} / \mathrm{kg} /$ day was derived for females in the study of van der Ven et al. (2006) but no effects on thyroid were observed in males.

Eriksson et al. (2006) conducted a test monitoring behavioural effects after a cavage of HBCDD to male mice 10 days after birth at dose levels 0.9 or $13.5 \mathrm{mg} / \mathrm{kg}$ body weight. HBCDD was dissolved in a mixture of egg lecithin and peanut oil. Several behavioural endpoints were observed and the results indicate that HBCDD can cause developmental neurotoxic effects at low exposure levels. Clear effects on all parameters were observed at $13.5 \mathrm{mg} / \mathrm{kg}$, and on some parameters at $0.9 \mathrm{mg} / \mathrm{kg}$ dose level, providing an indicative LOAEL of $0.9 \mathrm{mg} / \mathrm{kg} / \mathrm{day}$. Due to the nonstandard nature of the method and some uncertainties in the results, it has been considered by European Commission (2007a) to be necessary, that the results would be confirmed by other laboratories. Two other studies on neurotoxicity (Mariussen and Fonnum, 2003; Lilienthal et al., 2006) also provide indications of neurotoxicity of HBCDD at cellular level in vitro and in vivo.

No fetotoxic or teratogenic potential was seen in two tests according to OECD 414 (Murai et al., 1985; Stump, 1999). A maternal NOAEL of $75 \mathrm{mg} \mathrm{HBCDD} / \mathrm{kg} /$ day was determined by Murai et al. (1985) (13\% increase in liver weight in the next higher dose of $750 \mathrm{mg} / \mathrm{kg} /$ day).

Zeller and Kirsch (1969) observed signs of inhibited oogenesis in a 28 -days repeated dose study in rats at $4700 \mathrm{mg} / \mathrm{kg} / \mathrm{day}$ level. In addition, the prostate weight was dose-dependently increased in a 90-days study in rats reaching statistical significance at $1000 \mathrm{mg} / \mathrm{kg} /$ day level (Chengelis, 2001). There were also few observations of uterus swelling in a 18months study in mice at a dose of $1300 \mathrm{mg} / \mathrm{kg} /$ day than in the controls (Kurokawa et al., 1984). Although the indices have been observed at very high exposure levels, considering the very high bioaccumulation potential of HBCDD and the ability to be transfered to milk (see section 6.3.2), multi-generation studies with mammals should be conducted (ideally with specific diastereomers).

HBCDD was not observed to be mutagenic and it caused no indications of carcinogenity in the studies reviewed by European Commission (2007a).

A NOAEL for risk assessment purposes has been derived for repeated dose toxicity in the EU risk assessment of HBCDD (European Commission, 2007a). The NOAEL $=22.9 \mathrm{mg} / \mathrm{kg}$ bw/day based on the 28 -day 
study of van der Ven et al. (2006) with rats. It is noted, that the NOAEL of $0.9 \mathrm{mg} / \mathrm{kg}$ bw from the study of Eriksson et al. (2006) for developmental neurotoxicity is considered as a relevant endpoint, but the results need to be confirmed by other laboratories due to methodological uncertainties (European Commission, 2007a).

\subsubsection{Summary and conclusion}

Results from acute and long-term aquatic ecotoxicity studies are available for fish, daphnids and algae (freshwater and saltwater). In addition, longterm tests with three sediment organisms, terrestrial plants and earthworm are available. Based on the long-term ecotoxicity test with Daphnia magna (28d-NOEC $3.1 \mu \mathrm{g} / 1$; Drottar and Krueger, 1998) and on the growth inhibition test with Skeletonema costatum (72h-EC50 $52 \mu \mathrm{g} / \mathrm{l}$; Desjardins et al., 2005), HBCDD is considered as very toxic to aquatic organisms. It is noted, that aquatic ecotoxicity tests with specific diastereomers have not been conducted and that the tests have been complicated due to the very low apparent water solubility of HBCDD. Effects were not seen in the two available fish tests at the limit of the apparent (but not actual) water solubility limit of HBCDD, but most of the available invertebrate and algae tests support the conclusion. Adverse effects can also be anticipated to occur at environmentally relevant exposure levels based on the 28d-NOEC $3.1 \mathrm{mg} / \mathrm{kg}$ dw for Lumbriculus variegatus (Oetken et al., 2001). In addition, effects were observed in earthworm reproduction rate (NOEC $59 \mathrm{mg} / \mathrm{kg} \mathrm{dw}$; Aufderheide et al., 2003), but no effects were observed in plants at the highest levels tested $(5000 \mathrm{mg} / \mathrm{kg}$ dw; Porch et al., 2002).

According to the available laboratory studies with mammals, HBCDD is not carcinogenic, mutagenic or toxic to reproduction. HBCDD was observed to cause effects in repeated dose studies in liver, thyroid gland and thyroid hormone homeostasis. A NOAEL of $22.9 \mathrm{mg} / \mathrm{kg}$ bw/day for liver weight increase (van der Ven et al., 2006) was the lowest observed NOAEL in the available repeated dose studies with oral administration. Furthermore, developmental neurotoxicity and changes in sexual organs were observed, but these findings need to be confirmed by additional studies including properly designed multi-generation studies.

Based on HBCDDs high aquatic ecotoxicity, it is concluded, that HBCDD clearly fulfils the toxicity screening criteria set for POPs. The various adverse effects observed in laboratory in mammals provide an additional concern. 


\section{Statement of the reasons for concern and need for global action}

HBCDD is highly toxic to aquatic organisms. According to laboratory tests with mammals, it affects the functioning of the thyroid system and liver. The available data contain also indications of effects on fertility and developmental neurotoxicity of mammals, which need to be addressed in further studies. The monitoring data available from remote areas provide an unevitable evidence, that HBCDD is transported over long distances in the environment. Temporal series of concentrations of HBCDD in birds and marine mammals show an increasing trend in remote areas as well as in regions closer to the sources. HBCDD is based on measured data widespread in the global environment. HBCDD has been detected in the majority of samples in the abiotic environment, biota and/or humans of the Arctic, Europe, Asia and North and South America regions. Furthermore, HBCDD is degraded slowly in the aquatic environment and soil. HBCDD has a great potential for bioaccumulation via direct uptake from water and via food. It has been observed to biomagnify in laboratory tests (with fish and mammals) and in the environment. HBCDD is according to the available data also transferred from mother to child during pregnancy via blood and after delivery via breast feeding. Also the general human population is exposed to HBCDD based on measured data.

HBCDD is used as a flame retardant in a wide variety of articles in all parts of the world. The largest share of HBCDD is used in polystyrene products, but textiles have also been identified to be a relevant application. The releases, as quantified in Europe, are at present entering the environment mainly from a large number of industrial point sources. However, HBCDD is also released from articles during and at the end of their service-life, but the quantification of these releases is uncertain at present. In addition, the volume of HBCDD increases in the built technosphere (articles in use) constantly, and future releases are therefore unpredictable. As HBCDD is long-range transported far from its sources, single countries or groups of countries alone cannot abate the pollution caused by it. Due to the harmful POP properties and risks related to its widespread production and use, international action is warranted to control this substance.

On the basis of the data available, the concerns listed above cover the whole commercial HBCDD. In addition, due to the evidence of, i.a., thermal rearrangement and bioisomerisation, possible differences in the 
properties of individual diastereomers do not seem at present to be relevant regarding the concern. 


\section{Additional information on hexabromocyclododecane}

\subsection{Sources}

\subsubsection{Production and market volume}

According to industry, HBCDD production is located in the U.S., Asia, Israel and Europe (BSEF, 2006). Table 6.1 presents estimates of industry on the consumption of the most used brominated flame retardants in 2001 or 2002 .

Table 6.1 Global consumption of three major brominated flame retardants (BSEF, 2003, 2004a,b)

\begin{tabular}{|c|c|c|c|c|c|}
\hline & $\begin{array}{l}\text { European con- } \\
\text { sumption (t/a) }\end{array}$ & $\begin{array}{r}\text { Asia to- } \\
\text { tal/Japan (t/a) }\end{array}$ & U.S.A (t/a) & $\begin{array}{r}\text { Remaining areas } \\
\text { (=global-the three } \\
\text { areas) }\end{array}$ & $\begin{array}{l}\text { Global con- } \\
\text { sumption (t/a) }\end{array}$ \\
\hline TBBPA (2002) & 7800 & $\begin{array}{r}110 \text { 000/not } \\
\text { available }\end{array}$ & 12200 & 0 & (>) 130000 \\
\hline $\begin{array}{l}\text { Decabromo diphe- } \\
\text { nylether (2001) }\end{array}$ & 7600 & $23000 / 2580$ & 24500 & 1000 & 56100 \\
\hline HBCDD (2001) & 9500 & $3900 / 2200$ & 2800 & 2200 & 16700 \\
\hline
\end{tabular}

In the European Union HBCDD is produced at present only at one site in the Netherlands. Two production sites closed in the autumn 2003. The production volume in the EU is assumed to be $6000 \mathrm{t} / \mathrm{a}$. The market volume for the substance in the EU is estimated based on information on the volumes of specific uses to be $9618 \mathrm{t} / \mathrm{a}$ and import $5500 \mathrm{t} / \mathrm{a}$ (European Commission, 2007a). No direct information on export volumes is available, but based on the previous volumes, export of $1882 \mathrm{t} / \mathrm{a}$ results (production+import-consumption $=$ export). Information on the import volume of HBCDD in end-products is not available. According to European Commission (2007a), HBCDD is produced also in Japan and the U.S. and it has been on the market since the 1960's. Environment Canada (2006) indicates, that HBCDD is produced or imported in Canada under the CAS number 3194-55-6 (but not under the CAS 25637-99-4).

\subsubsection{Uses}

HBCDD is solely used as an additive flame retardant on its own or in combination with other flame retardants. According to European Commission (2007a), the use of HBCDD can be allocated to four main cate- 
gories according to the material where HBCDD is used, whereas a large variety of end-products are manufactured from the flame retarded material. The major volume of HBCDD (90\%) is used in polystyrene applications.

Table 6.2 Uses of HBCDD according to European Commission (2007a).

\begin{tabular}{|c|c|c|}
\hline Material & Use/Function & End-products (examples) \\
\hline \multirow[t]{5}{*}{ Expandable polystyrene (EPS) } & \multirow[t]{5}{*}{ Insulation } & $\begin{array}{l}\text { Construction, insulation boards, (packaging } \\
\text { material) }\end{array}$ \\
\hline & & $\begin{array}{l}\text { Packaging material (minor use and not in } \\
\text { food packaging) }\end{array}$ \\
\hline & & $\begin{array}{l}\text { Insulation boards (against cold or warm) of } \\
\text { transport vehicles e.g. lorries and caravans }\end{array}$ \\
\hline & & $\begin{array}{l}\text { Insulation boards in building constructions } \\
\text { e.g. houses' walls, cellars and indoor cei- } \\
\text { lings and "inverted roofs" (outdoor) }\end{array}$ \\
\hline & & $\begin{array}{l}\text { Insulation boards against frost heaves of } \\
\text { road and railway embankments }\end{array}$ \\
\hline \multirow[t]{4}{*}{ Extruded polystyrene (XPS) } & \multirow[t]{4}{*}{ Insulation } & Construction, insulation boards, \\
\hline & & $\begin{array}{l}\text { Insulation boards (against cold or warm) of } \\
\text { transport vehicles e.g. lorries and caravans }\end{array}$ \\
\hline & & $\begin{array}{l}\text { Insulation boards in building constructions } \\
\text { e.g. houses' walls, cellars and indoor cei- } \\
\text { lings and "inverted roofs" (outdoor) }\end{array}$ \\
\hline & & $\begin{array}{l}\text { Insulation boards against frost heaves of } \\
\text { road and railway embankments }\end{array}$ \\
\hline \multirow[t]{3}{*}{ High impact polystyrene (HIPS) } & \multirow{3}{*}{$\begin{array}{l}\text { Electrical and electro- } \\
\text { nic parts }\end{array}$} & Electric housings for VCR \\
\hline & & $\begin{array}{l}\text { Electrical and electronic equipment e.g. } \\
\text { distribution boxes for electrical lines }\end{array}$ \\
\hline & & Video cassette housings \\
\hline \multirow{7}{*}{$\begin{array}{l}\text { Polymer dispersion on cotton or } \\
\text { cotton/synthetic blends }\end{array}$} & \multirow[t]{7}{*}{ Textile coating agent } & Upholstery fabric \\
\hline & & bed mattress ticking \\
\hline & & $\begin{array}{l}\text { Flat and pile upholstered furniture (residen- } \\
\text { tial and commercial furniture), }\end{array}$ \\
\hline & & Upholstery seatings in transportation, \\
\hline & & draperies, and wall coverings, \\
\hline & & Interior textiles e.g. roller blinds \\
\hline & & automobile interior textiles \\
\hline
\end{tabular}

The life cycle of HBCDD includes production, micronising (grinding to smaller particles; not complete production volume), formulation, compounding, industrial use of the compounded material and professional and consumer end-use. HBCDD containing material ends after the service life to recycling, landfill, as waste remaining in the environment or incineration (see Table 6.3).

\subsubsection{Releases to the environment}

Due to its use in plastics and the variety of end-uses, HBCDD is expected to be released from a large number of point sources and to some extent from professional and consumer end uses and during and after the ser- 
vice-life. Hundreds of industrial sites release HBCDD in the European Union. HBCDD is not known to have any natural sources. Table 6.3 presents the identified life cycle stages and sites of release (European Commission, 2007a).

Table 6.3. Life cycle stages of HBCDD, corresponding use volumes and the number of industrial sites in the EU (EU-15) (European Commission, 2007a).

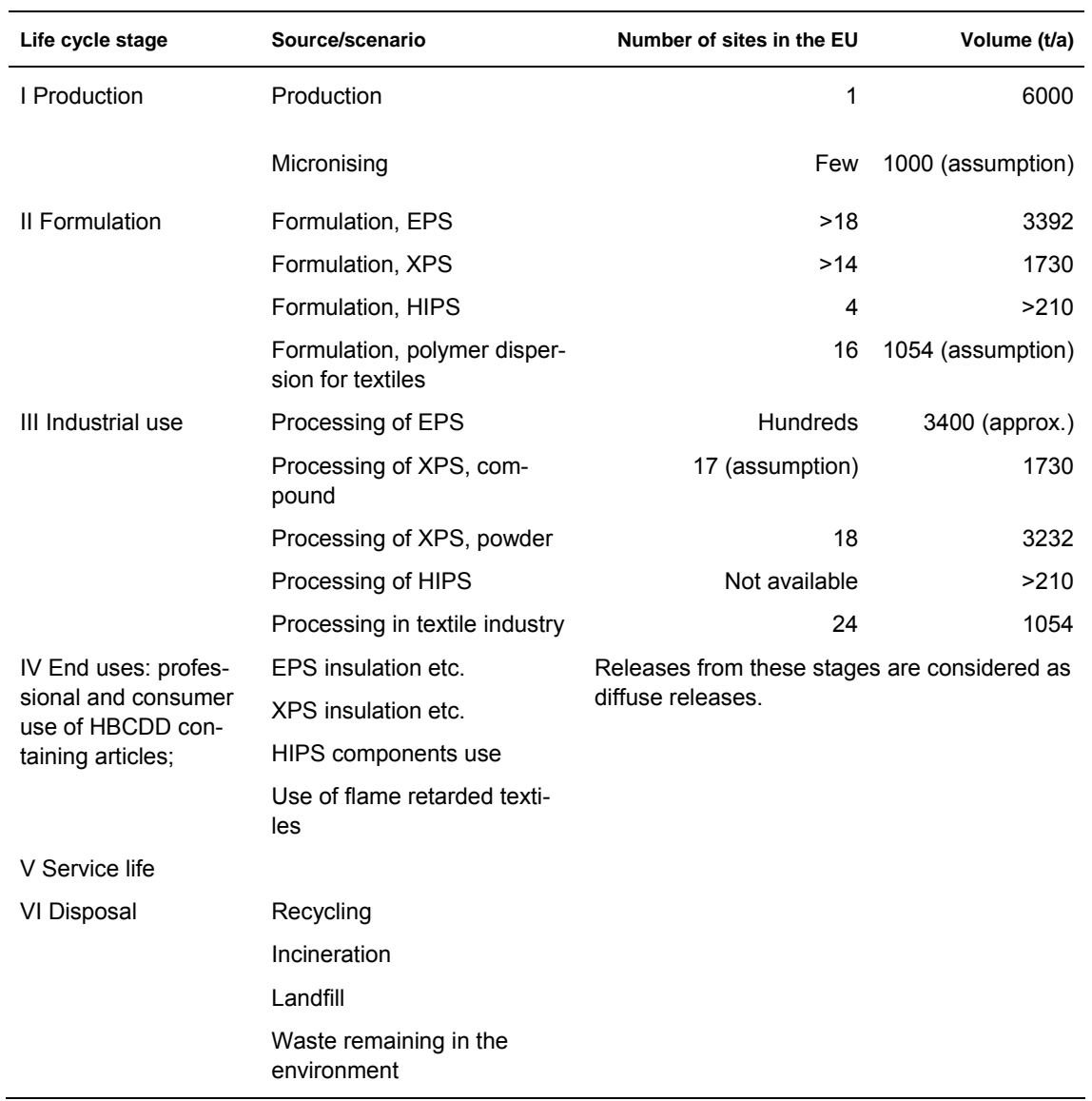

The European releases have been estimated using site-specific information on releases where available (ca. 40 sites in total provided data) and applying the information to the remaining sites. In some cases, where no appropriate site-specific information has been available, the OECD Emission Scenario Document on Plastic Additives (OECD, 2004) was applied. Table 6.4 presents the overview of the releases from point sources and from those diffuse sources, for which the releases could be quantified. 
Table 6.4 Total European (EU-15) releases of HBCDD and the share of industrial/point sources and some diffuse sources* of the releases (compiled from the data in European Commission, 2007a).

\begin{tabular}{|c|c|c|c|}
\hline & $\begin{array}{l}\text { Total European releases } \\
(\mathrm{kg} / \mathrm{a})\end{array}$ & $\begin{array}{l}\text { Share of industrial point } \\
\text { sources of the releases } \\
\text { (stages I, II and III) }\end{array}$ & $\begin{array}{l}\text { Share of professional use } \\
\text { and service life of the } \\
\text { releases (stage IV) }\end{array}$ \\
\hline Air & 508 & $53.6 \%(272.4 \mathrm{~kg} / \mathrm{a})$ & $46.4 \%$ (236 kg/a) \\
\hline Waste water** & 6251 & $98.1 \%(6133.3 \mathrm{~kg} / \mathrm{a})$ & $1.9 \%(117.5 \mathrm{~kg} / \mathrm{a})$ \\
\hline Surface water & 1933 & $89.2 \%(1723.8 \mathrm{~kg} / \mathrm{a})$ & $10.8 \%(209.0 \mathrm{~kg} / \mathrm{a})$ \\
\hline
\end{tabular}

It is noted, that diffuse releases were estimated for non-particulate (dissolved and volatilised) releases except for textiles, where wearing was accounted for. Releases from waste in industrial processing were included in the point source release estimates. Releases from landfills, from waste remaining in the environment and from demolition and renovation of buildings have not been quantified.

For the comparison, the amount of pentabromodiphenyl ether released from articles in use and waste remaining in the environment was in total $65 \mathrm{t} / \mathrm{a}$ (diffuse sources) and $330 \mathrm{~kg} / \mathrm{a}$ from industrial point sources (European Commission, 2001).

The majority of the European industrial sites formulating and processing (stages II and III in Table 6.3) HBCDD release based on limited site specific data and other information their waste water to municipal sewage treatment plants (European Commission, 2007a). These stages were estimated to contribute the main part of the quantified European releases to waste water (see Table 6.4). Consequently, a large amount of municipal sewage treatment plants (stp) are redirecting HBCDD from industrial point sources via municipal sludge (for the distribution in stp, see section 6.2) to agricultural soils in Europe.

HBCDD has been found in most sludge samples of European municipal sewage treatment plants (stp) at concentrations up to a median conc. of $1439 \mu \mathrm{g} \mathrm{HBCDD} / \mathrm{kg} \mathrm{dw}$ in Ireland (de Boer et al., 2002). Concentrations in Swedish stp sludge from plants without known or anticipated HBCDD point sources connected were according to Nylund et al. (2002) between 4 and $78 \mu \mathrm{g} \mathrm{HBCDD} / \mathrm{kg}$ dw regardless of the size of the stp. The results indicate a steady contribution of diffuse releases of HBCDD from consumer products and other articles during service life.

Leonards et al. (2001) and Santillo et al. (2003) found HBCDD in several countries in dust of different building types, including homes, in concentrations up to $12000 \mu \mathrm{g} \mathrm{HBCDD} / \mathrm{kg}$ dust, whereas the concentrations e.g., in France varied between 160 and $1600 \mu \mathrm{g} \mathrm{HBCDD} / \mathrm{kg}$ dust $(\mathrm{n}=38)$. These findings provide also evidence that HBCDD is released 
from flame-retarded materials in the technosphere during their servicelife.

Measured data from landfill leachate show that HBCDD is regularly found in particulate but also in dissolved phase of landfill leachate. For example, particulate phase of leachate in nine Dutch landfills contained 15-22 $000 \mu \mathrm{g} \mathrm{HBCDD/1} \mathrm{(de} \mathrm{Boer} \mathrm{et} \mathrm{al.,} \mathrm{2002).} \mathrm{In} \mathrm{the} \mathrm{study} \mathrm{of} \mathrm{Fjeld} \mathrm{et} \mathrm{al.}$ (2005) from landfills in Norway, the concentrations in untreated leachates collected from 10 sites were considerably lower (0.0002-0.15 $\mu \mathrm{g}$ $\mathrm{HBCDD} / 1)$.

No estimates of the releases in other continents are available but due to the highest market volume in Europe of all regions, the European estimates represent probably the realistic worst-case estimates for other regions.

\subsection{Environmental fate}

Based on the very low water solubility and high logKow, HBCDD is expected to have a very high adsorption potential to organic matter. No studies on the adsorption potential are available. A $\operatorname{logKoc}$ of 4.66 has been estimated by European Commission (2007a).

Distribution of HBCDD is presented below based on three models. For all models the following properties have been used:

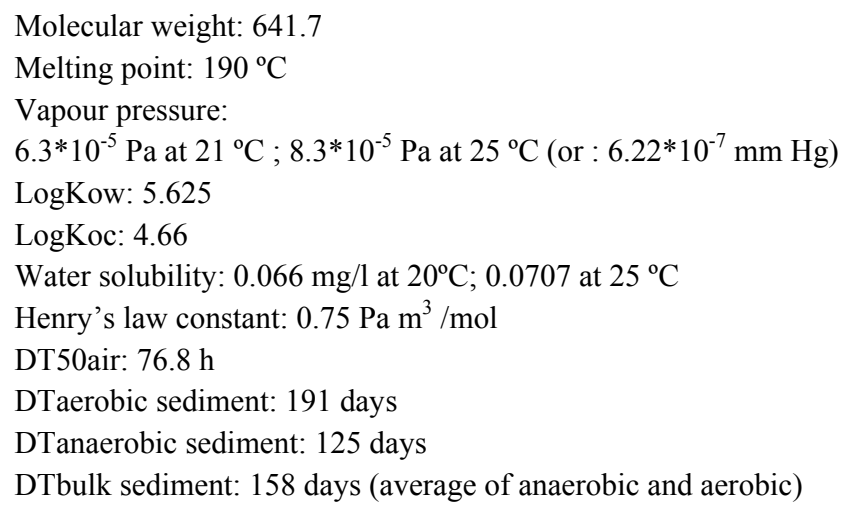

Distribution in a standard municipal wastewater treatment plant (stp) according to SimpleTreat model (as incorporated to EUSES 2.0.3) is:

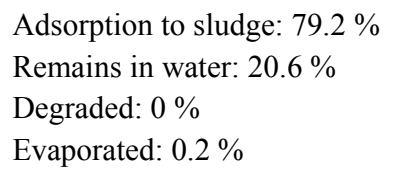

If degradation rate of HBCDD is set in the model optimal (= readily biodegradable), the removal by degradation would be $28.7 \%$, fraction directed to effluent $6.7 \%$ and fraction directed to sludge $64.6 \%$. Hence, it 
can be assumed, that the majority of HBCDD is directed to sludge regardless of the conditions for biodegradation in sewage treatment plants.

For the comparison, removal rates at five municipal sewage treatment plants located at Lake Mjøsa, Norway, have been determined based on measured data in the influent, effluent and sludge. The removal rates of each plant were between 27 and $89 \%$ in the year 2006. The overall removal rate for the total incoming HBCDD load of these plants was calculated at $79 \%$. The sewage treatment plants consisted of two sites with (mechanical, ) chemical and biological treatment, whereas three plants had mechanical and chemical treatment in place (Fjeld et al., 2007).

Distribution in a model environment was calculated with Level III program and with the same properties as above to be $0.0023 \%$ to air, $0.061 \%$ to water, $99.8 \%$ to soil and $0.101 \%$ to sediment. Equal emission load (1000 kg/hour) to water, air and soil were used and the DT50 in water and soil was set to $6 * 10^{5}$ hours. When excluding the emission to soil, Level III -model calculates the distribution as $0.04 \%$ to air, $0.65 \%$ to water, $98.2 \%$ to soil and $1.07 \%$ to sediment.

EUSES 2.0.3 program, which is used for risk assessment purposes in the EU, provides the following (Table 6.5) steady-state distribution in the regional and continental models representing the European environment and in the arctic environment. The European releases have been put into the model as provided in Table 6.4.

Table 6.5 Steady-state mass fractions for the EUSES default environments using the European releases from European Commission (2007a)

\begin{tabular}{|c|c|c|c|c|c|c|}
\hline & \multicolumn{2}{|c|}{$\begin{array}{r}\text { Regional }^{1)} \text { steady-state mass } \\
\text { ( } \% \text { or total) }\end{array}$} & \multicolumn{2}{|c|}{$\begin{array}{r}\text { Continental }^{2)} \text { steady-state } \\
\text { mass (\%) }\end{array}$} & \multicolumn{2}{|c|}{$\begin{array}{r}\text { Global }^{3)} \text { arctic steady- } \\
\text { state mass (\%) }\end{array}$} \\
\hline & $\begin{array}{r}\text { DT50sediment } \\
=158 \mathrm{~d} 4)\end{array}$ & $\begin{array}{r}\text { DT50 } \\
\text { sediment } \\
=\infty\end{array}$ & $\begin{array}{r}\text { DT50 } \\
\text { sediment }= \\
158^{*} \mathrm{~d}\end{array}$ & $\begin{array}{r}\text { DT50 } \\
\text { sediment }= \\
\infty\end{array}$ & $\begin{array}{r}\text { DT50 } \\
\text { sediment } \\
=158^{*} \mathrm{~d}\end{array}$ & $\begin{array}{r}\text { DT50 } \\
\text { sediment } \\
=\infty\end{array}$ \\
\hline Freshwater & $<0.01$ & $<0.01$ & 0.01 & 0.018 & 0.84 & 3.07 \\
\hline Seawater & $<0.01$ & $<0.01$ & 0.5 & 0.929 & & \\
\hline Air & 0.0003 & 0.0003 & 0.002 & 0.003 & 0.0001 & 0.0002 \\
\hline $\begin{array}{l}\text { Soil (agric.+ } \\
\text { natural) }\end{array}$ & 44.8 & 37.6 & $\begin{array}{r}50.4 \\
\left(6.31^{*} 10^{5}\right. \\
\mathrm{kg})\end{array}$ & $\begin{array}{r}43.4 \\
\left(6.41 * 10^{5}\right. \\
\mathrm{kg})\end{array}$ & 0.06 & 0.135 \\
\hline $\begin{array}{l}\text { Freshwater sedi- } \\
\text { ment }\end{array}$ & 0.05 & 0.18 & 0.07 & 0.372 & 0.03 & 0.194 \\
\hline Marine sediment & $<0.01$ & $<0.01$ & 0.03 & 0.294 & & \\
\hline
\end{tabular}

1) The regional model has a size of $4104 \mathrm{~km}^{2}$

2) The contintental model has a size of $3.56 * 10^{6} \mathrm{~km}^{2}$

3) The arctic model $4.25 * 10^{7} \mathrm{~km}^{2}$

4) It is noted, that the total mass in the system is smaller when using DT50 or 158 than with infinite half-life in sediment. Therefore the \%-values between the two degr.rate scenarios are not directly comparable.

Based on the EUSES modeling, it is concluded, that largest share of HBCDD released in Europe is expected to be found in the European soil. The compartment volumes for the regional and continental models are: air $>$ water $\approx$ soil $>$ sediment. Distribution of the total HBCDD mass in 
the Arctic in different compartments is: water $>$ sediment $>$ soil $>>$ air, when a very slow degradation in sediment is assumed. The continental model compartment volumes are: air $>$ water $>$ sediment $\approx$ soil. It is noted, that the EUSES model does not take wind erosion into account.

\subsection{Exposure}

\subsubsection{Environmental exposure}

Data on concentrations of HBCDD in surface water are available mainly from recipients of major point sources (NL, UK). Due to the very high adsorption potential and low water solubility, concentrations in dissolved phase are not expected to be very high. The concentrations have remained mainly below $1 \mu \mathrm{g} / 1$ (e.g., Deuchar, 2002 and U.K. Environment Agency, 2006). The only reported concentrations from seawater (suspended solids) are $74 \mu \mathrm{g} / \mathrm{kg} \mathrm{dw}$ and $472 \mu \mathrm{g} / \mathrm{kg} \mathrm{dw}$ in Western Scheldt and Tern canal (NL, Terneuzen), respectively, in the vicinity of a production plant (Bouma, et al. 2000).

Fjeld et al. (2006b) measured recently HBCDD concentrations in sediment samples of the largest Norwegian lake Lake Mjøsa. The results from dated sediment layers of a sediment core sample, where highest concentrations were found, are presented in Figure 6.1. The sampling site was one of the deep areas of the lake (site Vingrom; sample taken at a depth of $84 \mathrm{~m}$ ). The dated sediment cores from three other deep areas contained HBCDD in concentrations $<1 \mu \mathrm{g} / \mathrm{kg} \mathrm{dw}$. The higher concentrations at Vingrom site could be explained with the vicinity of a textile factory in Lillehammer city area. The factory used HBCDD in their production in recent years. The is use started in the end of 1990 and ended in 2003. Interestingly, $\alpha$-HBCDD was the predominant diastereomer found in the sediment samples. In another recent study, Berge et al. (2007) found $\gamma$-HBCDD to contribute most to the total HBCDD concentrations in surface sediment samples taken in 2006 in the fjord area Ålesund in Norway. The concentrations at nine sampling sites were between 0.69 and $54.2 \mu \mathrm{g} \sum \mathrm{HBCDD} / \mathrm{kg}$.

Measured data from European freshwater sediments are presented in Figure 6.2. The data have been extracted from Anonymous (2002a), de Boer et al. (2002), Deuchar (2002), Eljarrat et al. (2004), Fjeld, et al. (2004), Kohler et al. (2006), Schlabach et al. (2004), Sellström et al. (1998), Sternbeck et al. (2001) and U.K.Environment Agency (2006). Mean concentration of the data from these authors is $394 \mu \mathrm{g} \mathrm{HBCDD} / \mathrm{kg}$ $\mathrm{dw}$ and range $0.05-33350 \mu \mathrm{g} \mathrm{HBCDD} / \mathrm{kg} \mathrm{dw}$. A mean of $35 \mu \mathrm{g}$ $\mathrm{HBCDD} / \mathrm{kg} \mathrm{dw}$ and a range of 0.05-511 $\mu \mathrm{g} \mathrm{HBCDD} / \mathrm{kg}$ dw result when data from 15 sites reflecting the impact of a certain point source are removed (European Commission, 2007a). 


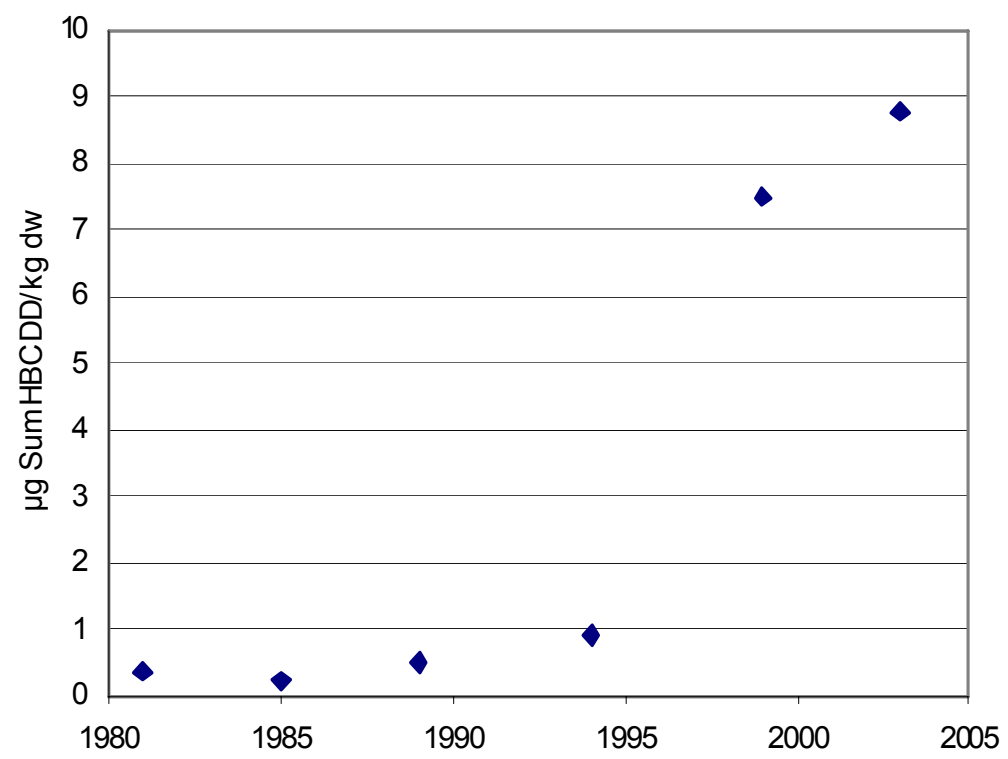

Figure 6.1. Concentration of HBCDD (sum of $\alpha$-, $\beta$ - and $\gamma$-HBCDD) in Lake Mjøsa dated sediment core sample from Vingrom deep (data from Fjeld et al., 2006b).

Marvin et al. (2006) analysed HBCDD in suspended sediments from the River Detroit (border of Canada and the U.S.), which flows through a highly industrialised area. The concentrations ranged from $<0.025$ to 1.9 $\mu \mathrm{g} / \mathrm{kg} \mathrm{dw}$ for $\alpha-\mathrm{HBCDD},<0.025$ to $0.28 \mu \mathrm{g} / \mathrm{kg}$ dw for $\beta$-HBCDD and $<0.025$ to $2.3 \mu \mathrm{g} / \mathrm{kg} \mathrm{dw}$ for $\gamma$-HBCDD. The concentrations of total HBCDD varied from $<0.075$ to $3.7 \mu \mathrm{g} / \mathrm{kg}$. Roughly two-thirds of HBCDD profiles in suspended sediments were dominated by the $\gamma$ diastereomer, and were similar to profiles of commercial technical mixtures. Profiles in the remaining samples were dominated by the $\alpha$ diastereomer.

For estuarine, brackishwater and marine sediments of Norway, the Netherlands and Ireland a mean concentration of $174 \mu \mathrm{g} \mathrm{HBCDD} / \mathrm{kg} \mathrm{dw}$ and a range of 0.25-8 $024 \mu \mathrm{g} \mathrm{HBCDD} / \mathrm{kg}$ dw have been reported by European Commission (2007a). When excluding nine sites affected directly by point sources, a mean of $11 \mu \mathrm{g} \mathrm{HBCDD} / \mathrm{kg} \mathrm{dw}$ and a range of $0.25-128 \mu \mathrm{g} \mathrm{HBCDD} / \mathrm{kg} \mathrm{dw}$ resulted. 


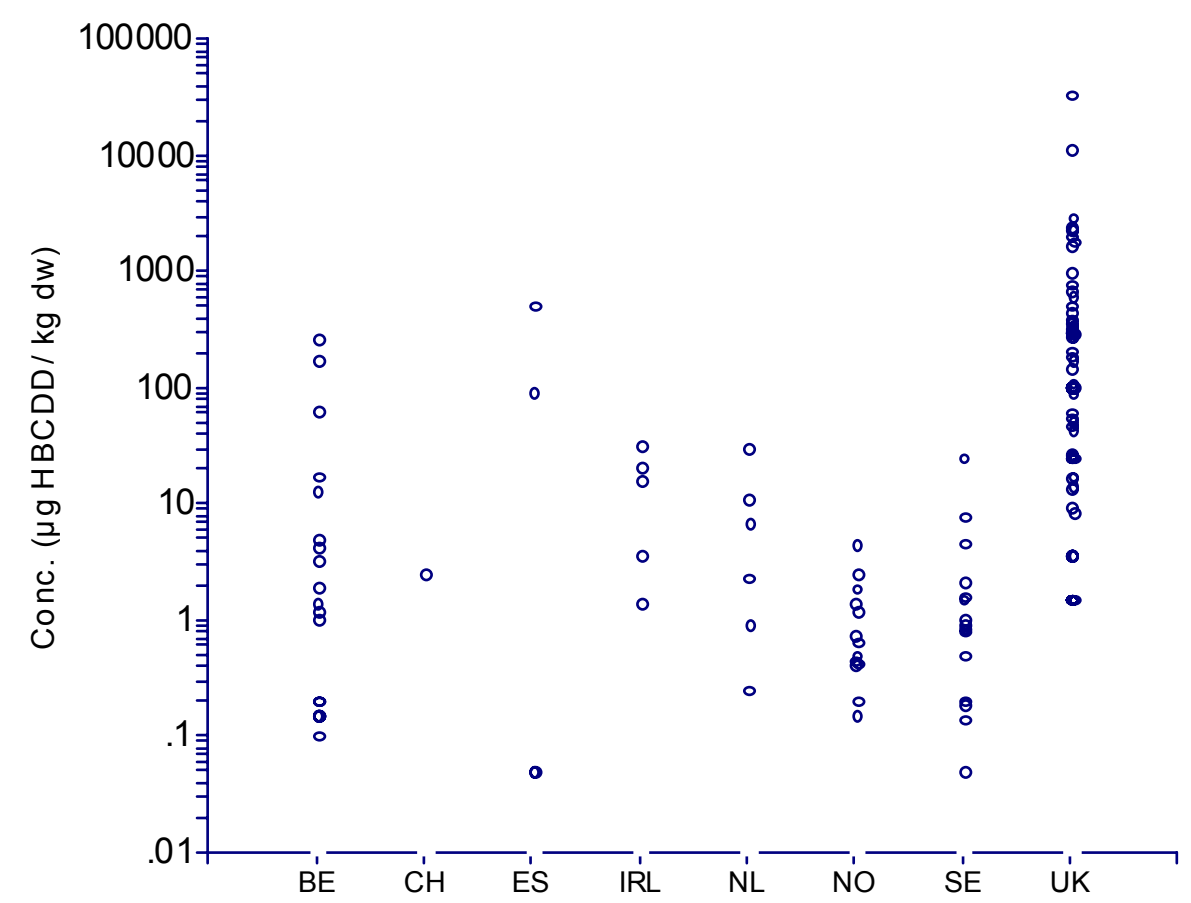

Figure 6.2 Concentration of HBCDD in European freshwater sediments as compiled by European Commission (2007a). Values below the detection limit are set at half detection limit.

Data on concentrations in air are still scarce and span depending on the location from < LOD to $0.28 \mathrm{ng} \mathrm{HBCDD} / \mathrm{m}^{3}$ in locations reflecting regional background concentrations (Bergander et al., 1995; Sternbeck et al., 2001) and at urban locations or locations close to point sources from 0.013 to $1070 \mu \mathrm{g} \mathrm{HBCDD} / \mathrm{m}^{3}$ (Sternbeck et al., 2001; Waindzioch, 2000).

In Norway in the Ålesund area, Schlabach and Gjerstad (2005) measured HBCDD concentrations in moss samples representing the growth (and deposition) of years 2005, 2004 and 2003. They found a mean concentration of $35 \mu \mathrm{g} / \mathrm{kg}$ dw (min-max of $0.86-118$ ) in samples collected from eight sites for the sum of the three main diastereomers. $\gamma$-HBCDD contributed most to the total HBCDD concentrations. Based on the results on moss, analyses of soil samples (see below) and model estimates the authors concluded, that the local waste incinerator was not likely to be a source of HBCDD but the measured concentrations were attributed to an industrial site using HBCDD for production of flame retarded polystyrene. Furthermore, Mariussen et al. (2005) found in moss samples collected from 16 Norwegian background areas a mean of $0.52 \mu \mathrm{g} / \mathrm{kg} \mathrm{dw}$ (min-max of 0.21-1.09) for the sum of the three main diastereomers.

Measured data from soil are available from sites reflecting impact of point sources from five studies (Anonymous, 2000d,e; Sternbeck et al., 2001; Jansson 2004; Schlabach and Gjerstad, 2005). Sternbeck et al. (2001) found a concentration gradient of $1.3,1.0$ and $0.14 \mathrm{mg}$ $\mathrm{HBCDD} / \mathrm{kg} \mathrm{dw}$ when measuring HBCDD at distances of $300 \mathrm{~m}$ south, 
$500 \mathrm{~m}$ southeast and $700 \mathrm{~m}$ northwest, respectively around a plant producing XPS in Sweden. The concentrations in soil samples collected in 2005 in the Ålesund area, Norway, reflecting HBCDD input via deposition were $4 \mu \mathrm{g} / \mathrm{kg} \mathrm{dw}$ (Spjelkavik), $2 \mu \mathrm{g} / \mathrm{kg} \mathrm{dw}$ (Breivik) and $0.1 \mu \mathrm{g} / \mathrm{kg}$ $\mathrm{dw}$ (Godøy) for the sum of $\alpha-, \beta$ - and $\gamma$-HBCDD (Schlabach and Gjerstad, 2005). $\gamma$-HBCDD contributed most to the total HBCDD concentrations.

Concentrations in biota have been measured in various studies, whereas the largest number of observations is available for marine mammals followed by birds and fish. The European data have been compiled exhaustively by European Commission (2007a) and only the core findings are presented below.

The geometric mean concentration in freshwater fish muscle $(\mathrm{n}=151)$ in Europe has been estimated to be $4.64 \mu \mathrm{g} \mathrm{HBCDD} / \mathrm{kg}$ ww based on all available data. The corresponding median concentration is $5.5 \mu \mathrm{g}$ $\mathrm{HBCDD} / \mathrm{kg}$ ww and arithmetic mean $321 \mu \mathrm{g} \mathrm{HBCDD} / \mathrm{ww}$. The values included contain a range of $<$ LOD to $9432 \mu \mathrm{g} \mathrm{HBCDD} / \mathrm{kg}$ ww. For data from areas without a direct impact of point sources and excluding the natural background areas, a median concentration of $20 \mu \mathrm{g} \mathrm{HBCDD} / \mathrm{kg}$ ww $(n=52)$ has been calculated. This value was chosen to represent so called regional concentration in the EU risk assessment. The levels of HBCDD in European freshwater fish are presented in Figure 6.3.

Levels in marine and brackish water fish muscle $(n=102)$ range from $<$ LOD to $49 \mu \mathrm{g} \mathrm{HBCDD} / \mathrm{kg}$ ww with a mean of $2.6 \mu \mathrm{g} \mathrm{HBCDD} / \mathrm{kg} \mathrm{ww}$ (European Commission, 2007a). Considering that fish eating predators are digesting mainly whole fish, and that concentration of HBCDD in most other organs is expected to be higher than in the muscle, the predators are exposed to higher concentrations via fish diet than indicated by these values.

Exposure to HBCDD is confirmed also to occur in China, where Xian et al. (2007) measured HBCDD in the lower reach of the Yangtse River in fish. Samples of seventeen specimens belonging to nine freshwater species were analysed and HBCDD was found in all samples. Concentration in muscle was $12-330 \mu \mathrm{g} / \mathrm{kg} \mathrm{lw}(\mathrm{n}=16)$ for total HBCDD. The concentration of $\alpha$-HBCDD and $\gamma$-HBCDD was found to be $7.2-120 \mu \mathrm{g} / \mathrm{kg}$ $1 \mathrm{w}$ and $1.7-200 \mu \mathrm{g} / \mathrm{kg} \mathrm{l} \mathrm{w}$ in muscle, respectively, whereas the concentrations of the $\alpha$-diastereomer were in general the highest of the three main diastereomers measured. According to Ueno et al. (2006), HBCDD was also detected in skipjack tunas in the Asian-Pacific region collected from offshore waters. HBCDD was found in almost all samples in concentrations of $<0.1$ to $45 \mu \mathrm{g} / \mathrm{kg}$ lw and $\alpha$-HBCDD was the predominating diastereomer. 


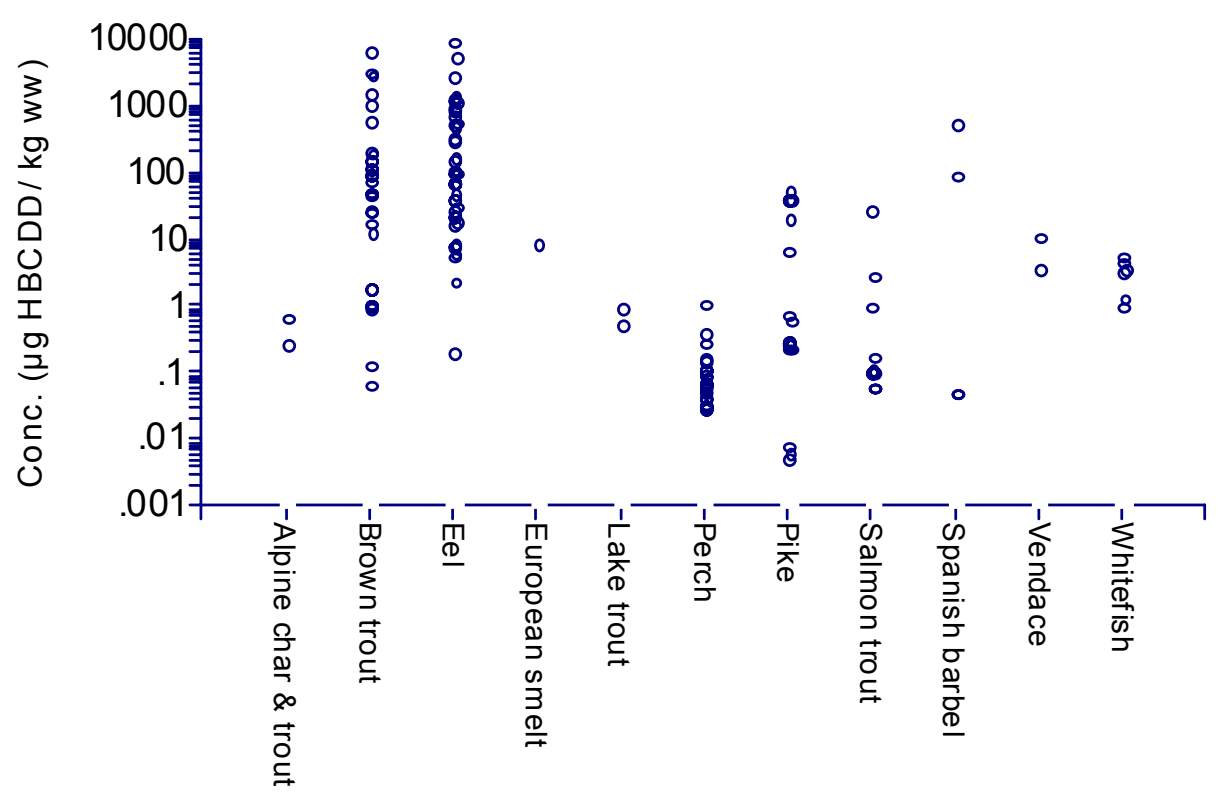

Figure 6.3 Concentration of HBCDD in fish muscle from European freshwaters (compiled by European Commission, 2007a)

HBCDD has been found in marine mammals in European, North American and North-Eastern Asian marine environment. For 225 analysed samples in Europe, the concentrations in seal, porpoise and dolphin range from 0.5 to $6400 \mu \mathrm{g} \mathrm{HBCDD} / \mathrm{kg}$ body weight with a mean of $498 \mu \mathrm{g}$ $\mathrm{HBCDD} / \mathrm{kg}$ body weight (lw corrected to bw in $1 / 3$-relation if necessary) (European Commission, 2007a).

HBCDD was measured by Law RJ et al. (2006) in blubber of 85 harbour porpoises stranded or dying in the U.K. during 1994-2003. The mean concentration in the mid 1990s was $100 \mu \mathrm{g} / \mathrm{kg}$ lw and increased to $9400 \mu \mathrm{g} / \mathrm{kg} \mathrm{lw}$ in the samples from the year 2003. The increase was observed to be independent of age, sex, nutritional status and location.

Stapleton et al. (2006) report on an increasing temporal trend of HBCDD in blubber from 26 male California sea lions $(0.7 \mu \mathrm{g}$ $\mathrm{HBCDD} / \mathrm{kg} \mathrm{ww}$ in 1993; $12 \mu \mathrm{g} \mathrm{HBCDD} / \mathrm{kg} w \mathrm{w}$ in 2003).

An increasing temporal trend was also found in blubber of northern fur seals collected in 1990s from the Pacific coast of northern Japan (Kajiwara et al., 2006b). The concentrations seem to have levelled off based on mean concentrations, although the span of the results has increased in the later years. Isobe et al. (2007a) found for HBCDD an increasing temporal trend in finless porpoises collected between $1990(9.5 \mu \mathrm{g} / \mathrm{kg} \mathrm{lw}$ average) and 2001/0 (35 $\mu \mathrm{g} / \mathrm{kg}$ lw, average) in the South China Sea. Concentrations of HBCDD in Indo-Pacific humpback dolphins measured in the same study from samples of the same area were $31-380 \mu \mathrm{g} / \mathrm{kg} \mathrm{lw}$. 
HBCDD concentrations in blubber of six striped dolphins stranded at the coast of Japan were between 290 and $940 \mu \mathrm{g} / \mathrm{kg}$ lw (Isobe et al., 2007b).

The longest temporal series of concentrations measured in biota has been reported by Sellström et al. (2003) for the years 1969 to 2001 for guillemot (Uria aalge) eggs (see Figure 6.4) collected from the Baltic Sea. The area with highest concentrations found in birds is close to a major point source in the Netherlands, Terneuzen. In this area, eggs of common tern contained 35-640 $\mu \mathrm{g} \mathrm{HBCDD} / \mathrm{kg}$ ww (Bouma et al., 2000; de Boer et al., 2002).

Lundstedt-Enkel et al. (2006) measured concentrations of HBCDD and 13 other organohalogens (HCHs, HCB, PCBs, PBDEs, p,p'-DDE, $\mathrm{p}, \mathrm{p}-\mathrm{DDD}, \mathrm{p}, \mathrm{p}-\mathrm{DDT})$ in the Baltic Sea guillemot (Uria aalge) eggs $(\mathrm{n}=$ $30)$ and muscle $(n=20)$ and found that the relation of the concentration in eggs to the concentration in muscle was the highest (2.14; lw basis) for HBCDD of all measured substances. For half of the measured substances no significant difference was observed. The samples were collected in the years 2000-2002 and the geometric mean concentration in eggs was 138 $\mu \mathrm{g} \mathrm{HBCDD} / \mathrm{kg}$ lw. For the comparison, the sum concentration of five analysed tetra- to hexabrominated diphenyl ethers was $77.4 \mu \mathrm{g}$ PBDE $/ \mathrm{kg}$ $1 \mathrm{w}$ in eggs. The concentrations of p,p'-DDE and most PCB congeners analysed were one or two orders of magnitude higher than the level of HBCDD. For measured data in remote areas, see Table 4.10.

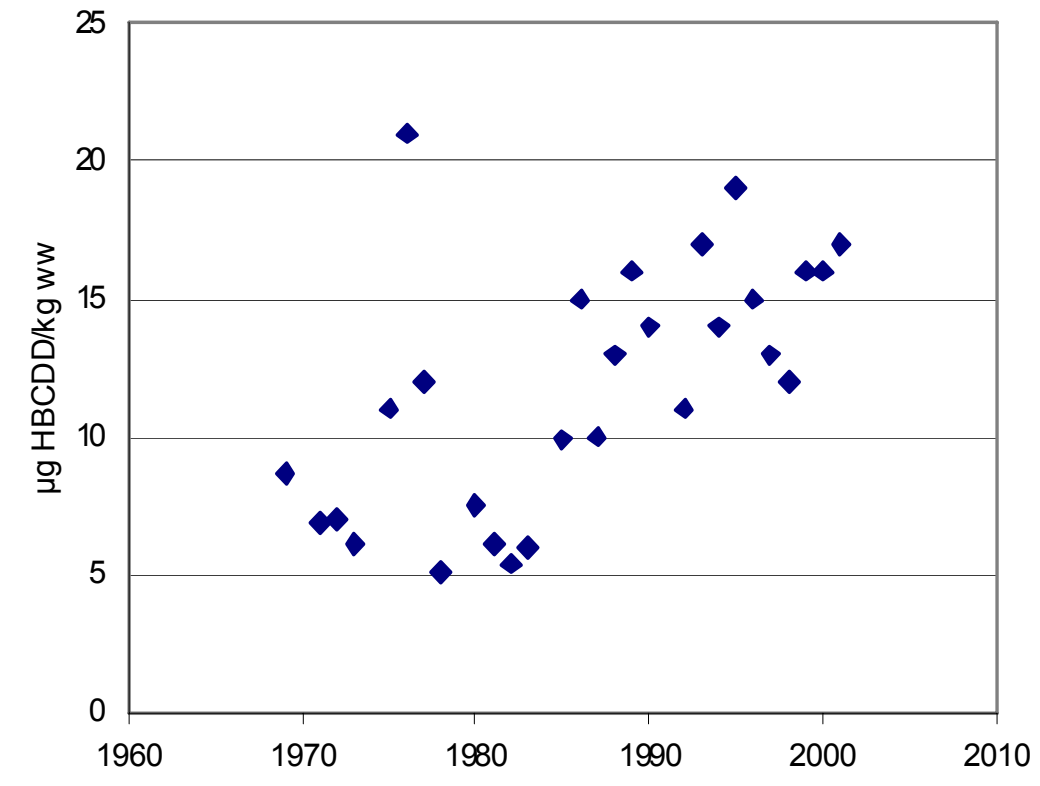

Figure 6.4 Concentration of HBCDD over time in guillemot (Uria aalge) eggs in the Baltic Sea (data from Sellström et al., 2003). 


\subsubsection{Exposure of man}

HBCDD has been analysed and detected in breast milk in Sweden, Norway and Mexico providing evidence, that breastfed babies are exposed to HBCDD via dietary route. The available data are compiled in Table 6.6.

Table 6.6 Concentration of HBCDD in breast milk

\begin{tabular}{|c|c|c|c|c|}
\hline Country & Year & $\begin{array}{r}\text { Number of } \\
\text { samples }\end{array}$ & $\begin{array}{l}\text { Concentration of HBCDD in breast milk } \\
\text { (ng/g lw) }\end{array}$ & Reference \\
\hline Sweden & & 12 & $0.45 ; 2.4$ (mean; max); LOD: 15 pg/g ww & $\begin{array}{l}\text { Aune et al. } \\
(2001)\end{array}$ \\
\hline Sweden & 2003 & 30 & $0.42 ; 1.5$ (mean; max); LOD: 6pg/g ww & $\begin{array}{l}\text { Lignell et al. } \\
(2003)\end{array}$ \\
\hline Norway & 1993-2001 & 10 & $0.25-2$ (min-max); & $\begin{array}{l}\text { Thomsen et al. } \\
\text { (2003) }\end{array}$ \\
\hline Sweden & 1980-2004 & See text & $0.084-0.60$ (min-max) & $\begin{array}{l}\text { Fängström et } \\
\text { al. (2005) }\end{array}$ \\
\hline Sweden & 2004 & 5 & $1.1(0.3-3.2)$ mean (min-max) & $\begin{array}{l}\text { Lopez et al. } \\
\text { (2004) }\end{array}$ \\
\hline Mexico & 2004 & 7 & $2.1(0.8-5.4)$ mean (min-max) & $\begin{array}{l}\text { Lopez et al. } \\
(2004)\end{array}$ \\
\hline
\end{tabular}

The study of Fängström et al. (2005) comprised analyses of pooled breast milk samples from the years 1980, 1984/1985, 1988, 1990 (two pools), 1992, 1994, 1995, 1996, 1997, 1999, 2001, 2002, 2003 and 2004. The number of samples in each pool was 116, 102, 20 (for the years 19882002), 15 and 20, respectively. The milk was collected from healthy native Swedish mothers in Stockholm and the average age of the mothers was 27-28 years in 1980 and 1984/1985, and between 29-31 years in 1988-2004. 55-80\% of mothers included were nursing their first infant. The results of the analyses are presented in Figure 6.5. It is noted, that the analysis method is not described in the report for HBCDD but only for polybrominated diphenyl ethers, which were also analysed from the samples. 


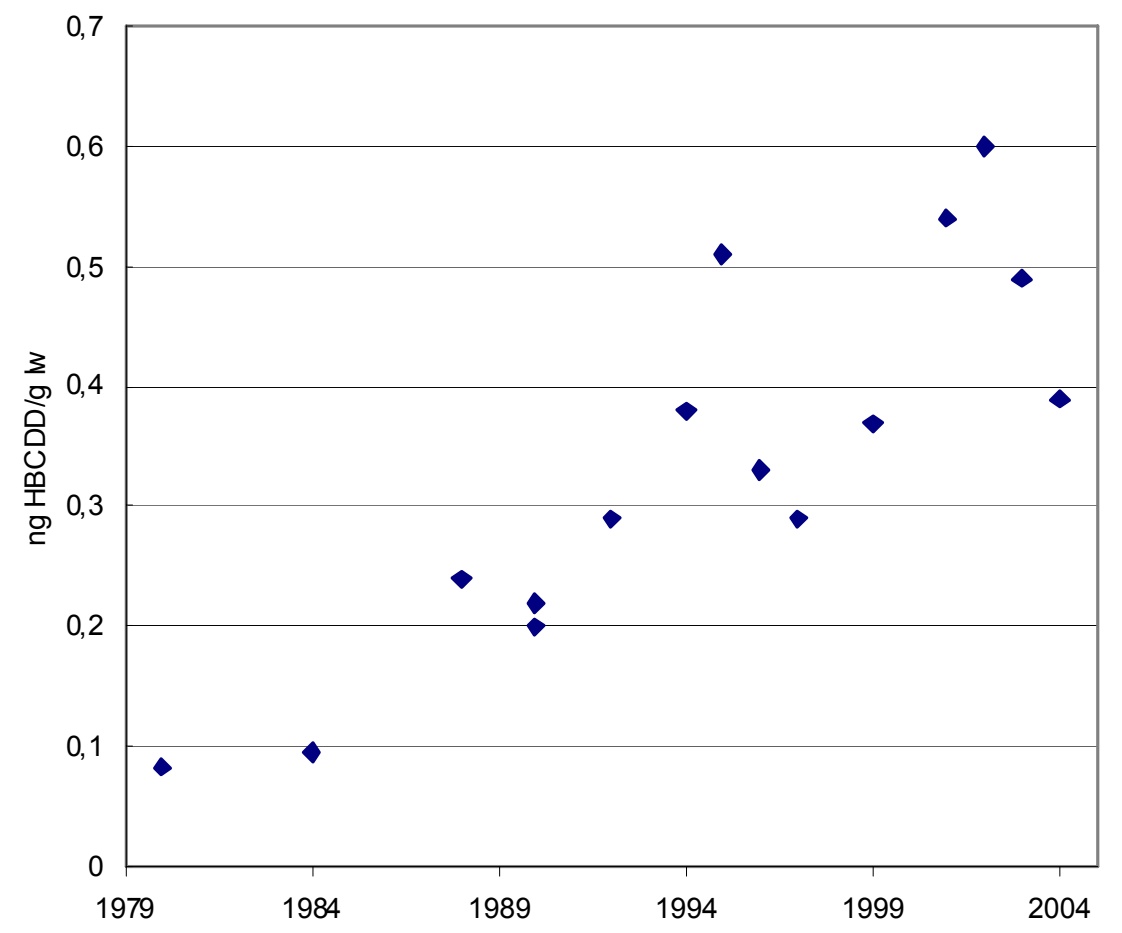

Figure 6.5 Concentration of HBCDD in breast milk of Swedish mothers in 1980-2004 (Fängström et al., 2005).

In the study of Lopez et al. (2004) also blood plasma of Mexican women was analysed and HBCDD was found in a mean concentration of $1.2 \mathrm{ng} / \mathrm{g}$ lw (range 0.7-2.5).

Weiss et al. (2004) reported on an analysis of HBCDD of blood serum samples of 78 Dutch women in different phases of pregnancy and from 12 cord blood serum samples representing the exposure of unborn child. HBCDD was detected almost in all samples. The mean concentration in maternal serum was $1.1 \mathrm{ng} / \mathrm{g}$ lw (range 0.16-6.9) and in cord blood 2.4 (range 0.16-4.2). Although the concentration on the lipid weight basis was similar, the total concentration in blood was higher in maternal blood than in cord blood. Concentrations of HBCDD were in the study within the same range or slightly lower than the concentrations of five included PBDE congeners in both cord and maternal serum.

Blood serum of elderly Swedish women being married with fishermen was sampled and analysed in two pools of 25 samples each. (-) $\alpha-$ HBCDD was the dominating diastereomer, with only a few percent contribution from $\gamma$-HBCDD Weiss et al. (2006).

HBCDD has also been detected in blood plasma of Norwegian and Russian mothers ( $\mathrm{n}=10$ in total) by Odland et al. (2005) and in one blood sample of 47 European MEPs (Brandsma et al., 2004). Thomsen et al. (2007) measured HBCDD in blood plasma of consumers of fish from the Norwegian Lake Mjøsa, which receives HBCDD effluents from industrial sites. The median serum concentration was 4.1 and $2.6 \mathrm{ng} / \mathrm{g} \mathrm{lw}$ for men 
and women, respectively ( $\mathrm{n}=66$ in total). In 49 samples, HBCDD concentration was above the LOQ. The HBCDD levels in blood were found according to the authors to be associated with self-reported consumption of fish from Lake Mjøsa (daily intakes were not quantified).

De Winter-Sorkina et al. (2003) have estimated a daily intake of the Dutch population using measured data on the concentrations of HBCDD in food from the Netherlands Institute for Fisheries Research (RIVO) and the consumption data from the third Dutch National Food Consumption Survey (DNFCS). The concentration of HBCDD was determined in 91 samples from the food categories dairy, meat, animal fat, eggs, fish and vegetable oil. HBCDD was present in 15 out of 18 food categories. HBCDD could not be detected in $54 \%$ of the samples. The food groups with the highest contributions to the total intake of HBCDD were beef, poultry and vegetable oils and fats. The total average dietary intake of HBCDD by the Dutch population was $2.9 \mathrm{ng} / \mathrm{kg}$ bwt/day (results $<$ LOD set to $0.5 * \mathrm{LOD}$ ) or $1.5 \mathrm{ng} / \mathrm{kg}$ bwt/day (results $<$ LOD set to zero).

Knutsen et al. (2007) calculated the mean dietary exposure of HBCDD to be $0.3 \mathrm{ng} / \mathrm{kg}$ bw/day for a group of Norwegians $(\mathrm{n}=184)$ having variable seafood consumption habits. The primary source of HBCDD was identified to be oily fish. The estimate was based on measured data from 27 food products (for most products several replicate samples were analysed).

According to European Commission (2007a), based on the representative regional concentration in EU freshwater fish (to $20 \mu \mathrm{g} / \mathrm{kg}$ ww; measured) a daily intake of HBCDD with frequent fish consumption $(0.115$ $\mathrm{kg} /$ day and a human body weight of $70 \mathrm{~kg}$ ) is approximately $33 \mathrm{ng} / \mathrm{kg}$ bw/day. If the median concentration of the measured data on freshwater fish muscle $(5.5 \mu \mathrm{g} / \mathrm{kg} \mathrm{ww})$ is used instead, a daily intake of $9 \mathrm{ng} / \mathrm{kg}$ bw/day results.

\subsection{National and international administrative actions on hexabromocyclododecane}

\subsubsection{Classification and labelling}

HBCDD is not yet officially classified in the European Union. The EU risk assessment of HBCDD (European Commission, 2007a), proposed the following classification according to Directive 67/548/EEC:

\begin{tabular}{ll}
\hline $\mathrm{N} ; \mathrm{R} 50-53$ & $\begin{array}{l}\text { Very toxic to aquatic organisms, may cause long-term adverse effects in the } \\
\text { aquatic environment }\end{array}$ \\
\hline
\end{tabular}


The reported L(E)C50 range of 10-100 $\mu \mathrm{g} / 1$ will give rise to the following concentration limits of the substance in preparations:
$\mathrm{C} \geq 2.5 \%$
$\mathrm{N} ; \mathrm{R} 50-53$
$\mathrm{C} \geq 0.25 \%$
$\mathrm{N} ; \mathrm{R} 51-53$
$\mathrm{C} \geq 0.025 \%$
$\mathrm{R} 52-53$

\subsubsection{Other regulatory activities}

The EU risk assessment of HBCDD under the Existing Substances Regulation (93/793/EEC) has been finalised in 2007. Environmental risks on quantitative basis were identified for exposure situations in the impact areas of several industrial sources (see Appendix 4).

In addition, the substance has been identified to fulfil the overall PBT criteria as defined in the assessment guidance (European Commission, 2004). Consequently, no quantitative risk ratios were calculated for secondary poisoning endpoints (exposure via food chains) in the risk assessment. For PBT substances, minimisation of releases is foreseen in Europe. As the subsequent step, a risk reduction strategy (Swedish Chemicals Agency, 2007) identifying necessary actions has been compiled.

Risks for human health were identified for production of HBCDD regarding the exposure to fine grade powder for the repeated dose toxicity endpoints inhalation, dermal exposure and multiple exposure. Additionally, further information needs were identified for reproductive toxicity due to uncertainties with regard to human health effects related to the very high bioaccumulation of HBCDD, excretion of HBCDD to breast milk and possible effects on reproduction during a life-time exposure. These uncertainties should be covered with a multi-generation reproduction study in a rodent species. Furthermore, due to developmental neurotoxicity observed in one non-standard study, more information in this area was considered necessary.

HBCDD is included in the U.S.High Production Volume Challenge Program (CAS 3194-55-6). No final conclusions or hazard assessment have been derived so far (U.S.EPA, 2007).

According to Environment Canada (2006), hexabromocyclododecane (CAS 3194-55-6) has been evaluated to fulfil the environmental PBiT criteria of Canada. These substances will be subject to further scrutiny such as risk assessments. However, HBCDD is not subject to further action at the moment in Canada. 


\subsubsection{Status under international conventions}

An OECD SIDS Initial assessment Profile has been compiled by Sweden (OECD, 2007). The OECD SIAM 24, 2007, agreed, that the substance is subject to further work and the Parties are urged to carry out an exposure assessment (environment and human health) and, if indicated, a risk assessment.

HBCDD is included as part of certain brominated flame retardants group in the List of Substances for Priority Action of OSPAR Commission for the Protection of the Marine Environment of the North-East Atlantic. The strategy to be followed is awaiting for the outcome of the EU risk assessment.

\subsubsection{Voluntary actions of industry}

According to EBFRIP (2007), bromine industry has launched "the Voluntary Emissions Control Action Programme for Brominated Flame Retardants" (VECAP). The program aims at the control of emissions from production and from industrial use of HBCDD in textile and plastics. HBCDD is targeted at present under VECAP in Europe and Japan. The voluntary emission control for the industrial use of HBCDD in polystyrene is foreseen to be covered by another program. 


\section{Alternatives and pollution prevention techniques}

Swedish Chemicals Agency (2007) has reviewed in "Strategy for limiting risks" the available information on the alternative substances and technologies of HBCDD. In the following, the information is briefly summarised, and the strategy is referred to for further details.

For the main use of HBCDD -the use in EPS and XPS in insulation materials-, no chemical alternatives are available on the market. However, alternatives of EPS and XPS are available. These are mineral insulation materials, which do not need flame retardant and rigid polyurethane foam, for which alternative flame retardants are available. A mechanical alternative for HBCDD would be an encasing of EPS or XPS into fireproof casings, but this solution could be used only in a limited amount of applications.

For the use of HBCDD in textiles, alternative chemicals are commercially available. These are: reactive phosphorous constituents, ammonium polyphosphates and diammonium phosphate. These alternatives are deemed less dangerous than HBCDD. Also intumescent systems have been described as alternatives to HBCDD, but their applicability in all textile uses is questionable.

For HBCDD used in high impact polystyrene (HIPS), chemical alternatives are available. The most common alternatives are other brominated flame retardants in connection with antimony trioxide. A non-brominated alternative is for some uses a combination of copolymer of HIPS together with polyphenylene oxide (PPO) and a flame retardant. As flame retardant, triphenylphosphate can be applied in HIPS-PPO.

The main part of HBCDD is emitted from industrial point sources according to the EU risk assessment (European Commission, 2007a). Therefore, in case the use of HBCDD is continued, more efficient pollution prevention techniques at industrial sites producing and using HBCDD should be implemented. Based on the physical-chemical properties of HBCDD, a reduction of emissions to air and waste water at industrial sites can be expected to be achieved by enhancing the capacity of the pollution prevention systems already in place and/or improving their effectiveness. The best available pollution abatement and prevention techniques are described for polymer industry and textiles industry by European Commission (2003 and 2007b) in the "Reference Documents on Best Available Techniques" (BREFs). In the BREF for polymer industry, brominated flame retardants are mentioned separately, whereas in the BREF for textiles industry, they are not but belong to the "non- 
biodegradable" substances. It is noted, that both BREFs do not cover downstream industrial uses, such as the use at construction site or in funiture manufacture.

The releases from industrial sites to municipal wastewater treatment systems are in a model treatment plant trapped to sludge at a rate of ca. $80 \%$ of initial mass, whereas the remaining part is released with effluent. Even in treatment plants having optimal anaerobic degradation conditions, the removal by degradation would remain below $30 \%$ of the initial load and emission to aquatic environment would be ca $7 \%$ of the initial load (see section 6.2). Measures enhancing the removal rate of particulate matter at treatment plants would lead to the increased trapping of HBCDD to sludge. In order to reduce the overall release to the environment, anaerobic fermentation and/or incineration of sludge as an ultimate measure would be needed. 


\section{References}

Albermarle Corporation. 2005. IUCLID Data set 201-15946.

http://www.epa.gov/HPV/pubs/summ aries/cyclodod/c13459rr.pdf.

Albemarle Corporation. 1994;, Baton

Rouge, L.A. As cited in: European Commission, 2007a.

Anonymous. Sampling for priority chemicals in the environment. For Department for Environment, Food and Rural Affairs (DEFRA). Ref EPG/1/5/154. CEFAS Contract report, draft. 2002a; C1337, pp 12 pp. As cited in: European Commission, 2007a.

Anonymous. Environmental assessment of a European flame retardant coating manufacturing facility(Formulator/Compounder). 2000d; 10531-009-420/PAH-2, pp 17 pp. Dames \& Moore, Manchester, UK. As cited in: European Commission, 2007a.

Anonymous. Environmental assessment of a European flame retardant textile manufacturing facility (Backcoater). 2000e; 10531-009-420/PAH-3, pp 19 pp. Dames \& Moore, Manchester, UK. As cited in: European Commission, 2007a

AopWin v1.91. In: Episuite v3.12. U.S.EPA, 2000.

Aufderheide J, Jones A, MacGregor JA and Nixon WB. Effect of hexabromocyclododecane on the survival and reproduction of the earthworm, Eisenia fetida. 2003; ABC study No. 47222, pp pp 94. ABC Laboratories, Inc. and Wildlife International Ltd, Columbia, Missouri and Easton, Maryland, USA.

Aune $\mathrm{M}$ and et al. Resultatrapport till miljöövervakningen: Organiska miljögifter I bröstmjölk från Göteborg 2001. Avtalsnr 219 0108. 2001; Livsmedelsverket och YMK, Sahlgrenska Sjukhuset, Göteborg. Bergander L, Kierkegaard A, Sellström $\mathrm{U}$, Widequist $\mathrm{U}$ and de Wit C. Are brominated flame retardants present in ambient air? 1995; Poster, 6th
Nordic Symposium on Organic Pollutants, Smygehuk, September 1720, 1995.

Berge JA, Schlabach M and Hareide NR. Kartleggning av bromerte flammehemmere, klor- og bromorganiske forbindelser, kvikksølv og metylkviksølv i fjorder naer Ålesund. 2006, Norsk institutt for vannforskning, Rapport 54362006, 18.6.2007.

Beyer A and Matthies M. Environmental long-range transport and persistence of substances. ELPOS 1.0.1, Feb 1st, 2002. Institute for Environmental Systems Research, University of Osnabrück, Germany.

Bouma S, Vethaak D, Meininger P and Holland A. De visdiefkolonie (Sterna hirundo) bij Terneuzen: blijven er problemen? De resultaten van een vervolgonderzoek in 2000. 2000; RIKZ-2000.45, pp 43. Rijksinstitut voor Kust en Zee/RIKZ, Middelburg, The Netherlands.

Brandsma SH, David F, de Boer J, Hodson S, Holmström K, Järnberg U, Jones KC, Kwadjik C, Leonards PEG, Leslie HA, Micic D, Thomas GO and van Hesseling JM. Analysis of manmade chemicals in human blood samples from 17 European countries. WWF detox campaign. 2004; pp 5291. WWF-Uk, Surrey, UK.

BSEF About Hexabromocyclododecane (HBCD). 2006. Bromine Science and Environmental Forum. http://www.bsef.com/env_health/hbcd /hbcd.php (accessed Jan 2008).

BSEF. Brominated Flame Retardant Decabromodiphenyl ether. 2004a. Fact sheet. Edition 2004. Bromine Science and Environmental Forum. BSEF. Brominated Flame Retardant TBBPA. 2004b. Fact sheet. Edition 2004. Bromine Science and Environmental Forum.

BSEF . Hexabromocyclododecane. Fact sheet. Edition 2003. Bromine Science and Environmental Forum. 
Chengelis CP. Amendment to the final report: A 90-day oral (gavage) toxicity study of HBCD in rats. 2002; WIL-186012, pp 280. Wil Reserach Laboratories, Inc, Ashland, Ohio, USA.

Chengelis CP. A 90-day oral (gavage) toxicity study of HBCD in rats. 2001; WIL-186012, pp 1527. Wil Reserach Laboratories, Inc, Ashland, Ohio, USA.

Chengelis CP. A 28-day repeated dose oral toxicity study of HBCD in rats. 1997; pp 925. WIL Research Laboratories, Inc, Ashland, Ohio, USA.

Christensen GN, Evenset A, Zaborska A, Berger U and Carroll J. Datering av sediment og historisk utvikling av miljøgifter i Ellasjøen, Bjørnøya. Akvaplan-niva rapport. 2004; APN514.2934, pp 35 pp. Akvaplan-niva, Tromsø, Norge.

Davis JW, Gonsior SJ, Markham DA and Marty GT. Investigation of the biodegradation of ${ }^{14} \mathrm{C}$ -

hexabromocyclododecane in sludge, sediment and soil. 2004; pp 113 pp.

Toxicology and Enviornmental Research and Consulting, The Dow Chemical Company, Midland, Michigan, USA.

Davis JW, Gonsior SJ and Marty GT. Evaluation of aerobic and anaerobic transformation of hexabromocyclododecane in aquatic sediment systems. 2003a; Project Study ID 021081, pp 87 pp. DOW Chemical Company, Midland,Michigan, USA.

Davis JW, Gonsior SJ and Marty GT. Evaluation of aerobic and anaerobic transformation of hexabromocyclododecane in soil. 2003b; Project Study ID 021082, pp 61 pp. DOW Chemical Company, Midland,Michigan, USA.

de Boer J, Allchin C, Zegers B, Boon JP, Brandsma SH, Morris S, Kruijt AW, van der Veen I, van Hesselingen JM and Haftka JJH. HBCD and TBBP-A in sewage sludge, sediments and biota, including interlaboratory study. 2002; C033/02, pp 40. RIVO Netherlands Institute for Fisheries Reserach, Wageningen, The Netherlands.
De Winter-Sorkina R, Bakker MI, Van Donkersgoed G and Van Klaveren JD. Dietary intake of brominated flame retardants by the Dutch population. 2003; pp 25. RIVM report 310305001, RIKILT repoer 2003.019, Bilthoven.

Desjardins D, MacGregor JA and Krueger HO. Final report. Chapter, Hexabromocyclododecane (HBCD): A 72-hour toxicity test with the marine diatom (Skeletonema costatum) using a co-solvent. Chapter 2, Hexabromocyclododecane (HBCD): A 72-hour toxicity test with the marine diatom (Skeletonema costatum) using generator column saturated media. 2005; pp pp19. Wildlife International, Ltd, Easton, Maryland, USA.

Desjardins D, MacGregor JA and Krueger HO.

Hexabromocyclododecane (HBCD): A 72-hour toxicity test with the marine diatom (Skeletonema costatum), Final report. 2004; pp 66. Wildlife Internation, Ltd, Easton, Maryland, USA.

Deuchar J. Draft. 2002; pp 20 pp. Enviroment Agency, National Laboratory Service, Nottingham, UK.

Drottar KR and Krueger HO.

Hexabromocyclododecane (HBCD):

A flow-through bioconcentration test with the rainbow trout (Oncorhynchus mykiss). Final report. 2000; 439A-

111, pp 1-137. Wildlife International Ltd, Easton, Maryland, USA.

Drottar KR and Krueger HO. Hexabromocyclododecane (HBCD): A flow-through life-cycle toxicity test with the cladoceran (Daphnia magna). Final report. 1998; 439A108 , pp 78 pp. Wildlife International Ltd, Easton, Maryland, USA.

Drottar KR, MacGregor JA and Krueger HO.

Hexabromocyclododecane (HBCD): An early life-stage toxicity test with the rainbow trout (Oncorhynchus mykiss). Final report. 2001; pp 1-102. Wildlife International, Ltd, Easton, Maryland, USA.

EBFRIP. VECAP, second annual progress report 2007. European Brominated Flame Retardant Industry Panel, Bromine Science and Environmental Forum. 
http://www.bsef.com/product_stew/ve cap/.

Eljarrat E, de la Cal A, Raldua D, Duran $\mathrm{C}$ and Barcelo D. Occurrence and bioavailability of polybrominated diphenyl ethers and hexabromocyclododecane in sediment and fish from the Cinca River, a tributary of the Ebro River (Spain). Environ Sci Technol 2004; 38: 26032608.

Environment Canada, 2006. Cepa Environmental Registry, DSL search online, http://www.ec.gc.ca/CEPARegistry/s ubs list/ds1/dslsearch.cfm.

EpiSuite v3.12. U.S.EPA, 2000.

Eriksson P, Fisher C, Wallin M, Jakobsson E and Fredriksson A. Impaired behaviour, learning and memory, in adult mice neonatally exposed to hexabromocyclododecane (HBCDD). Environ Toxicol Pharmacol 2006; 21: (3): 317-322.

European Commission, 2007a. Risk assessment of Hexabromocyclododecane, CAS-No.: 25637-99-4, EINECS-No.: 247-148-4. Final Draft, October, 2007.

European Commission, 2007b. Reference Document on Best Available Techniques, Polymers, August 2007. http://eippcb.jrc.es.

European Commission. Technical Guidance Document on risk assessment in support of Commission Directive $93 / 67 / \mathrm{EEC}$ on risk assessment for new notified substances, Commission Regulation (EC) No 1488/94 on risk assessment for existing substances, Directive 98/8/EC of the European Parliament and of the Council concerning the placing of biocidal products on the market. TGD, Part II. 2004. European Chemicals Bureaua, Institute for Gealth and Consumer Protection. EUR 20418 EN/2.

European Commission, 2003. Reference Document on Best Available Techniques for the Textiles Industry. July 2003. http://eippcb.jrc.es.

European Commission, 2001. Risk assessment of diphenyl ether, pentabromoderiv. (pentabromodiphenyl ether) CAS-No.: 32534-81-9; EINECS-No.: 251-084-2. Final re- port, August 2000. Published in 2001 EUR 19730EN.

EUSES 2.0.3. European Union System for Evaluation of Substances. http://ecb.jrc.it/euses/

Fängström B, Strid A and Bergman Å. Temporal trends of brominated flame retardants in milk from Stockholm mothers 1980-2004. 2005; pp 1-9. Department of Environmental Chemistry, University of Stockholm, Stockholm, Sweden. A report to Naturvårdsverket, Dnr 721-2653-05Mm, Stockholm 2005-11-23.

Fjeld E, Rognerud S, Enge EK, Borgen AR and Dye C. Tilførsel av miljøgifter til Mjøsa via kommunale renseanlegg og elver, 2006. Norsk institutt for vannforskning, juni 2007. Rapport 5444-2007.

Fjeld E. Bromerte flammehemmere mm. i fisk fra Mjøsa, 2005. 2006a; pp 7. Norsk institutt for vannforskning, Norge.

Fjeld E, Rognerud S, Enge EK, Borgen AR and Dye C. Miljøgifter i sedimenter fra Mjøsa, 2005-2006. 2006b. Statens forurensningstilsyn, Rapport 972/2006.

Fjeld E, Schlabach M, Berge JA, Green N, Eggen T, Snilsberg P, Vogelsang C, Rognerud S, Kjellberg G, Enge EK, Dye $\mathrm{C}$ and Gundersen $\mathrm{H}$. Bromerte flammehemmere, perfluoralkylstoffer, irgarol, diuron, BHT og dicofol. Kartlegging av utvalgte nye organiske miljøgifter 2004. 2005; 927, pp 105 pp. NIVA, Norge.

Fjeld E, Schlabach M, Berge JA, Green N, Eggen T, Snilsberg P, Källberg G, Rognerud S, Enge EK, Borgen A and Gundersen H. Screening of selected new organic contaminants brominated flame retardants, chlorinated paraffins, bisphenol A and triclosan. 2004; 4809-2004, pp 117 pp. NIVA, Norge.

Gabrielsen GW, Knudsen LB and Schlabach M. Organic pollutants in northern fulmars (Fulmarus glacialis) from Bjørnøya. SPFO-Report. 2005; 922/2005, pp 37 pp. Norwegian Polar Institute, Tromsø, Norway.

Gabrielsen GW, Knudsen LB, Verreault J, Push K, Muir DDC and Letcher RJ. Halogenated organic contaminants and metabolites in blood and adipose 
tissues of polar bears (Ursus maritimus) from Svalbard. SPFOReport. 2004; 915/2004, pp 32pp. Norwegian Polar Institute, Tromsø, Norway.

Gerecke AC, Giger W, Hartmann PC, Heeb NV, Kohler H-PE, Schmid P, Zennegg $\mathrm{M}$ and Kohler M. Anaerobic Degradation of brominated flame retardants in sewage sludge. Chemosphere, 2006, 64, 311-317.

Graves WC and Swigert JP.

Hexabromocyclododecane (HBCD): A 96-hour flow-through acute toxicity test with the rainbow trout (Oncorhynchus mykiss). Final report. 1997a; 439A-101, pp 70 pp. Wildlife Internationl Ltd, Easton, Maryland, USA.

Graves WC and Swigert JP.

Hexabromocyclododecane (HBCD): A 48-hour flow-through acute toxicity test with the Cladoceran (Daphnia magna). Final report. 1997b; 439A102, Wildlife International Ltd, Easton, Maryland, USA.

Great Lakes Chemical Corporation. 1994; West Lafayette, IN. As cited in: European Commission, 2007a.

Hayward S, Lei Y and Wania F. Comparative evaluation of three highperformance liquid chromatographybased Kow estimation methods for highly hydrophobic organic compounds: polybrominated diphenyl ethers and hexabromocyclododecane. Environ Toxicol Chem 2006; 25: (8): 2018-2027.

Heeb NV, Schweizer WB, Kohler M and Gerecke AC. Structure elucidation of hexabromocyclododecanes - a class of compounds with a complex stereochemistry. Chemosphere 2005; 61: 65-73.

Isobe T, Ramu K, Kajiwara N, Takahashi S, Lam P, Jefferson T, Zhou K. and Tanabe S. Isomer specific determination of hexabromocyclododecanes in small cetaceans from the South China Sea Levels and temporal variation. Marine Pollution Bulletin, 2007a 54(8):11391145.

Isobe T, Ochi Y, Ramu K, Yamamoto $\mathrm{T}$, Takahashi $\mathrm{S}$ and Tanabe $\mathrm{S}$. Contamination Status and Body Distribution of Organohalogen
Compounds in Striped dolphins (Stenella Coeruleoalba) Stranded at Gogo-shima Island, Matsuyama, Japan. 4th International Workshop on Brominated Flame Retardants, Amsterdam, the Netherlands, 2007. Conference Abstracts.

Janák K, Covaci A, Voorspoels S and Becher G. Hexabromocyclododecane (HBCD) in Marine Species from the Western Scheldt Estuary: Diastereoisomer - and Enantiomer specific accumulation. Environ Sci Technol 2005a; 39: (7): 1987-1994.

Janák K, Zegers BN, Mets A, Hamers $\mathrm{T}$, Becher $\mathrm{G}$ and Boon JP.

Enantiomer fractions of Hexabromocyclododecane in marine mammals from Western European Seas with evidence for enatiomerspecific biotransformation. Organohalogen compounds 2005b; 67:

Jenssen BM, Sørmo EG, Bæk K, Bytingsvik J, Gaustad H, Ruus A and Skaare JU. Brominated Flame retardants in North-East Atlantic Marine Ecosystems. Env. Health Persp., 2007, 115(S 1), 35-41.

Kajiwara N, Isobe T, Ramu K and Tanabe S. 2006b. As cited in: Takashi $\mathrm{S}$, Isobe T, Subramanian A, Takasuga T, Sakai S and Tanabe S. Recent studies on bromianted flame retardants in the Asia-Pacific Region. 2007. Abstract book of the 4th International Workshop on Brominated Flame retardants, Amsterdam, 2007.

Kirk-Othmer. Encyclopedia of chemical technology. Fourth edition. 1993. John Wiley \& Sons, New York, Chichester, Brisbane, Toronto, Singapore.

Knudsen LB, Sagerup K, Older A, Schlabach M, Josefsen TD, Strøm Hm Skåre JU and Gabrielsen GW. Halogenated Organic Contaminats and mercury in dead or dying seabirds on Bjørnøya (Svalbard). SPFOReport. 2007;977/2007. pp 45. Statens Forurensningstilsyn.

Knudsen LB, Gabrielsen GW, Verreault J, Barrett R, Skåre JU, Polder A and Lie E. Temporal trends of brominated flame retardants, cyclodeca-1,5,9triene and mercury in eggs of four seabird species from Northern Norway and Svalbard. SPFO-Report. 
2005; 942/2005, pp 43 pp. Norwegian

Polar Institute, Tromsø, Norway.

Knutsen H, Kvalem H, Thomsen C, Frøshaus M, Haugen M, Becher G, Alexander J and Meltzer H. Dietary exposure to brominated flame retardants correlate with male blood levels in a selected group of Norwegians with a wide range of seafood consumption. Molecular Nutrition and Food Research, Submitted in 2007.

Kohler M, Schmid P, Hartman PC, Sturm M, Heeb NV, Zennegg M, Gerecke AC, Gujer E, Kohler H-PE and Giger W. Occurrence and Temporal Trends of Hexabromocyclododecanes (HBCDs) in Swiss Lake Sediment. SETAC 2006;

Kurokawa Y, Inoue T, Uchida Y and Momma J. Carcinogenesis test of flame retarder hexabromocyclododecane in mice. (not published, translated into english). M. Hardy, Albemarle Corporation, personal communication. 1984; Department of Toxicology, National Public Health Research Institute, Biological Safety Test and Research Centre. As cited in: European Commission, 2007a.

Law K, Palace VC, Halldorson T, Danell R, Wautier K, Evans B, Alaee M, Marvin C and Tomy GT. Dietary accumulation of hexabromocyclododecane diasteroisomers in juvenile rainbow trout (Oncorhynchus mykiss) I: Bioaccumulation parameters and evidence of bioisomerization. Environ Toxicol Chem 2006a; 25: 1757-1761. Law K, Halldorson T, Danell R, Stern G, Gewurtz S, Alaee M, Marvin C, Whittle $\mathrm{M}$ and Tomy $\mathrm{G}$.

Bioaccumulation and trophic transfer of some brominated flame retardants in a lake Winnipeg (Canada) food web. Environ Toxicol Chem 2006b; 25: (8): 2177-2186.

Law K. ERRATUM. Environmental Toxicology and Chemistry 2007; 26 : (1): pp 190.

Law RJ, Bersuder P, Allchin CR and Barry J. Levels of flame retardants Hexabromocyclododecane and Tetrabromobisphenol A in the blubber of Harbour porpoises (Phocoena phocoena) stranded or bycaught in the U.K, with evidence for an increase in HBCD concentrations in recent years. Environ Sci Technol, 2006; 40(7), 2177-2183.

Leonards PEG, Santillo D, Brigden K, van der Veen I, v, Hesselingen J, de Boer $\mathrm{J}$ and Johnston P.Brominated flame retardants in office dust samples. In Abstracts from the second international workshop on brominated flame retardants - BFR 2001 Stockholm May 14-16. Edited by Asplund L and et al. 2001; pp 299302. AB Firmatryck, Stockholm.

Lignell $\mathrm{S}$ and et al. Persistent organic pollutants (POP) in breast milk from primiparae women in Uppsala County, Sweden, 2002-2003. Report to the Swedish Environmental Protection Agency. 2003;

Lilienthal H, van der Ven L, RothHaerer A, Hack A, Piersma A and Vos J. Neurobehavioral toxicity of brominated flame retardants: Differential effects of PBDE-99, TBBPA and HBCD and endocrine relation. 2006; pp 3.

López D, Athasiadou M, Athanassiadis I, Estrada LY, Díaz-Barriga F and Bergman Å.A preliminary study on PBDEs and HBCDD in blood and milk from Mexican women. In The third international workshop on brominated flame retardants - BFR 2004. Book of abstracts. Edited by Alaee $\mathrm{M}$ and et al. 2004; pp 483-487. Lundstedt-Enkel K, Asplund L, Nylund $\mathrm{K}$, Bignert A, Tysklind M, Olsson M and Örber J. Multivariate data analysis of organochlorines and brominated flame retardants in Baltic Sea guillemot (Uria aalge) egg and muscle. Chemosphere, 2006, 65, 1591-1599.

MacGregor JA and Nixon WB. Determination of water solubility of hexabromocyclododecane (HBCD) using a generator column method. 2004; pp 52. Wildlife International, Ltd, Easton, Maryland, USA.

MacGregor JA and Nixon WB. Hexabromocyclododecane (HBCD): Determination of n-octanol/water partition coefficient. 1997; 439C104, pp 68 pp. Wildlife International Ltd, Easton, Maryland, USA. 
Mariussen E, Steinnes E, Gundersen H, Borgen A and Schlabach M. Analysis of polybrominated diphenyl ethers in moss (Hylocomium splendens) from the Norwegian environment.

Organohal. Comp., 2005, 67, 591-

593. As cited in: Schlabach and Gjerstad, 2005.

Mariussen E and Fonnum F. The effect of brominated flame retardants on neurotransmitter uptake into rat brain synaptosomes and vesicles. Neurochem Int 2003; 43: 533-542.

Marvin CH, Tomy GT, Alaee M and MacInnis G. Distribution of hexabromocyclododecane in Detroit River suspended sediments. Chemosphere 2006, 64(2), 268-275.

Murai T, Kawasaki H and Kanoh S. Studies on the toxicity of insecticides and food additives in pregnant rats (7). Fetal toxicity of hexabromocyclododekane. Oyo Yakuri 1985; 29: 981-986.

Murvoll KM, Skaare JU, Jenssen H and Jenssen BM. Associations between organic pollutants and vitamin status in Brünnich's guillemot and common eider hatchlings. Sci Tot Env 2007 , 381, 134-145.

Nylund K, Haglund M, Berggren D, Kierkegaard A, Allan A, Asplund L and de Witt C. Bromerade flamskyddsmedel i avloppsslam analyser från 50 reningsverk i Sverige. 2002; 5188, pp 44 pp. Naturvårdsverket, Stockholm.

Odland JØ, Heimstad ES and Sandanger TM. Kartlegging av miljøgifter i humane blodprøver fra Taimyr, Russland og Bodø, Norge en pilotstudie av "nye" miljøgifter. Assessment of "new" contaminants in human blood samples from Taimyr, Russia and Bodø, Norway - a pilot study. 2005; SPFO-rapport: 930/2005, Statens forurensningstilsyn, Oslo, Norway. OECD. SIDS Initial Assessment Profile, Hexabromocyclododecane, CAS 25637-99-4, 3194-55-6. SIAM 24, 19-20 April, 2007.

OECD. Emission Scenario Document on Plastics Additives. OECD Series on Emission Scenario Documents No. 3. 2004;

Oetken M, Ludwichowski K-U and Nagel R. Validation of the preliminary EU-concept of assessing the impact of chemicals to organisms in sediment by using selected substances. 2001; UBA-FB 29967 411, pp 97 pp. Institute of Hydrobiology, Dresden University of Technology, Dresden, Germany.

Palm A, Sternbeck J, Embertsén L, Jonsson J and Mohlander U. Hexabromocyclododekan (HBCD) i Stockholm - modellering av diffusa emissioner. 2002; B 1465, pp 42 pp. Miljöförvaltningen, Stockholms Stad, Stockholm.

Peled M, Scharia R and Sondack D.Thermal rearrangement of hexabromocyclododecane (HBCD). In Industrial Chemistry Library. Advances in organobromine chemistry II. Edited by Desmurs J-R, Gérard B and Goldstein MJ 1995; 7, pp 92-99. Elsevier, Amsterdam, Lausanne, New York, Oxford, Shannon, Tokyo.

Porch JR, Kendall TZ and Krueger HO. Hexabromocyclododecane (HBCD): A toxicity test to determine the effects of the test substance on seedling emergence of six species of plants. Final report. 2002; pp 126 pp. Wildlife International, Ltd, Easton, Maryland.

Remberger M, Sternbeck J, Palm A, Kaj L, Strömberg K and BrorströmLundén E. The environmental occurrence of hexabromocyclododecane in Sweden. Chemosphere 2004; 54: 9-21.

Roberts CA and Swigert JP. Hexabromocyclododecane (HBCD): A 96-hour toxicity test with the freshwater alga (Selenastrum capricornutum). Final report. 1997; 439A-103, Wildlife International Ltd, Easton, Maryland, USA.

Santillo D, Labunska I, Davidson H, Johnston P, Strutt M and Knowles O. Consuming chemicals. Hazardous chemicals in house dust as an indicator of chemical exposure in the home. 2003a; GRL-TN-01-2003, pp 69 pp. Greenpeace Environmental Trust, London, UK.

Santillo D, Labunska I, Fairley M and Johnston P. Consuming chemicals \#2. Hazardous chemicals in house dust as indicators of chemical exposure in the home. 2003b; GRL-TN-02-2003, pp 
106 pp. Greenpeace European Unit, Brussles, Belgium.

Schaefer EC and Siddiqui AI. Hexabromocyclododecane (HBCD): an activated sudge respiration inhibitory test. 2003; 439A-108A, pp 32 pp. Wildlife Internationla Ltd, Easton, Maryland, USA.

Schaefer EC and Haberlein D. Hexabromocyclododecane (HBCD): Closed bottle test. 1996; 439E-102, Wildlife International Ltd, Easton, Maryland, USA.

Schlabach M and Gjerstad KI. Utslipp av bromerte flammehemmere til luft $\mathrm{i}$ Ålesund. Norsk institutt for luftforsknin, Kjeller, desember 2005. Report NILU OR 63/2005.

Schlabach M, Fjeld E and Borgen AR.Brominated flame retardants in Drammens river and the Drammensfjord, Norway. In The Third International Workshop on Brominated Flame Retardants - BFR 2004. Book of abstracts. Edited by Alaee $\mathrm{M}$ and et al. 2004; pp 147-150. Schlabach M, Mariussen E, Borgen A, Dye C, Enge E-K, Steinnes E, Green $\mathrm{N}$ and Mohn H. Kartlegging av bromerte flammehemmere og klorerte. 2002; 866/02, pp pp 69. SFT - Statlig program for forurensningsovervåking, NILU Norsk institutt for luftforskning, Oslo, Kjeller, Norway.

Sellström U, Bignert A, Kierkegaard A, Häggberg L, de Wit CA, Olsson M and Jansson B. Temporal trend studies on polybrominated diphenyl ethers and hexabromocyclododecane in guillemot egg from the Baltic Sea. Environ Sci Technol 2003; 37: (24): 5496-5501.

Sellström U, Kierkegaard A, de Wit C and Jansson B. Polybrominated diphenyl ethers and hexabromocyclododecane in sediment and fish from a Swedish river. Environ Toxicol Chem 1998; 17: (6): 1065-1072.

Smith K, Liu C-H, El-Hiti GA, Kang GS, Jonas E, Clement SG, Checquer $\mathrm{AD}$, Howarth OW, Hursthouse MB and Coles SJ. An extensive study of bromination of cis, trans-1,5,9cyclododecatriene: product structures and conformations. Org Biomol Chem 2005; 3: 1880-1892.
Sørensen PB, Vorkramp K, Thomsen M, Falk K and Møller S. Persistent organic pollutants (POPs) in the Greenland environment - Long-term temporal changes and effects on eggs of a bird of prey. NERI Technical Report. 2004; 509, pp pp 124.

National Environment Research Institute, Ministry of the Environment, http://www.dmu.dk/Udgivelser Sørmo EG, Salmer MP, Jenssen BM, Hop H, Bæk K, Kovac KM, Lydersen C, Falk-Petersen S, Gabrielsen GW, Lie E and Skaare JU.

Biomagnification of polybrominated diphenyl ether and

hexabromocyclododecane flame retardants in the polar bear food chain in Svalbard, Norway. Env.

Tox.Chem., 2006, 25(9), 2502-2511.

Stapleton HM, Dodder NG, Kucklick JR, Reddy CM, Schantz MM, Becker PR, Gulland F, Porter BJ and Wise SA. Determination of HBCD, PBDEs and MeO-BDEs in California sea lions (Zalophus californianus) stranded between 1993 and 2003. Mar Pollut Bull 2006, 52(5), 522-531.:

Stenzel JI and Markley BJ.

Hexabromocyclododecane (HBCD): Determination of the water solubility. 1997; 439C-105, pp 55 pp. Wildlife International Ltd, Easton, Maryland, USA.

Stenzel JI and Nixon WB.

Hexabromocyclododecane (HBC): Determination of the vapor pressure using a spinning rotor gauge. 1997; 439C-117, pp 44. Wildlife international Ltd, Easton, Maryland.

Sternbeck J, Remberger M, Kaj L, Strömberg K, Palm A and BrorströmLundén E. HBCD i Sverige screening av ett bromerat flamskyddsmedel. IVL Rapport. 2001; B1434, pp 39. IVL Svenska Miljöinstitutet AB, Stockholm.

Stump DG. Prenatal developmental toxicity study of hexabromocyclododecane (HBCD) in rats. 1999; pp 410. WIL Research Laboratories, Inc, Ashland, Ohio, USA.

Swedish Chemicals Agency, 2007. Strategy for limiting risks, hexabromocyclododecane (HBCDD). Draft of 4 September 2007. 
Thomas S, Krueger HO and Kendall TZ. Hexabromocyclododecane (HBCD): A prolonged sediment toxicity test with Hyalella azteca using spiked sediment with 5\% total organic carbon content. Final report. 2003; pp 102 pp. Wildlife International, Ltd, Easton, Maryland, USA.

Thomsen C, Knutsen H, Liane V, Frøshaug M, Kvalem H, Haugen, M, Meltzer H, Alexander J and Becher G. consumption of Fish from a Contaminated Late Strongly Affects the Concentrations of Polybrominated Diphenyl Ether and

Hexabromocyclododecane in Serum. Molecular Nutrition and Food Research. Submitted 2.7.2007.

Thomsen C, Frøshaug M, Leknes H and Becher G. Brominated flame retardants in breast milk from Norway. Organohalogen compounds 2003; 64:

Tomy G, Budakowski W, Halldorson T, Whittle M, Keir M and Alaee M. Biomagnification of $\alpha-$ and $\gamma$-hexabromocyclododecane (HBCDD) congeners in a Lake Ontario food web. Environ Sci Technol 2004a; 38: (8): 2298-2303.

Tomy G, Halldorson T, Budakowski W, Arsenault $\mathrm{G}$ and Marvin C. Isomerspecific analysis of hexabromocyclododecane by LC/MS/MS. In The third international workshop on brominated flame retardants - BFR 2004. Book of abstracts. Edited by Alaee M, 2004b; pp 301-304.

Tomy G, Budakowski W, Halldorson T, Whittle M, Keir M and Alaee M. Biomagnification of $\alpha-$ and $\gamma$-hexabromocyclododecane congeners in a Lake Ontario food web. Organohalogen Compounds 2003; 61: 111-114.

Ueno D, Alaee M, Marvin C, Muir D, Machinis G, Crozier P, Furdui V, Subramanian, A, Fillmann G, Zheng P, Mcuhtar M, Razak H, Prudente M, Chung K and Tanabe S. Distribution and transportability of hexabromocyclododecane in the AsiaPacific region using skipjack tuna as a bioindicator. Chemosphere 2006, 144(1):238-247.
U.K. Environment Agency. Review of 2005 UK Monitoring Data for HBCD. 2006;.

U.S.EPA. High Production Volume Information System, (online access 2007).

http://iaspub.epa.gov/oppthpv/quickse arch.chemical

van der Ven LTM, Verhoef A, van de Kuil T, Slob W, Leonards PEG, Visser TJ, Hamers T, Håkansson H, Olausson H, Piersma AH and Vos JG. A 28-day oral dose toxicity study of hexabromocyclododecane (HBCD) in Wistar rats. Toxicol Sci in press 2006;

Veith GD, Defoe DL and Bergstedt BV. Measuring and estimating the bioconcentration factor of chemicals in fish. J Fish Res Board Can 1979; 36: 1040-1048.

Verreault J, Gebbink Wa, Gauthier LT, Gabrielsen GW and Letcher RJ. Brominated Flame Retardants in Glaucuos Gulls from the Norwegian Arctic: More than just an Issue of Polybrominated Diphenyl Ethers. Environ Sci Technol 2007, 41: 49254931.

Verreault J, Gabrielsen GW, Letcher RJ, Muir DDC and Chu S. New and established organohalogen contaminants and their metabolites in plasma and eggs of glaucous gulls from Bear Island. SPFO-Report. 2004; 914/2004, pp 26 pp. Norwegian Polar Institute, Tromsø, Norway. Waindzioch A. Technical report of workplace air-measurements with respect to inhalable dust and hexabromocyclododecane (HBCD) at Broomchemie B.V., Terneuzen. 2000; 100/00443-00, pp 7. Institut Fresenius, Chemische und Biologische Laboratorien $\mathrm{GmbH}$, Taunusstein, Germany. As cited in: European Commission, 2007a.

Walsh GE, Yoder MJ, McLaughlin LL and Lores EM. Responses of marine unicellular algae to brominated organic compounds in six growth media. Ecotoxicolocy and Environmental Safety 1987; 14: (3): 215-222.

Wania F. Assessing the long-range transport potential of tetrabromobisphenol A and hexabromocyclododecane using 
several multimedia transport models. A report to BSEF. 2003; pp 13 pp. WECC Wania Environmental Chemsists Corp.

Wania F and Dugani CB. Assessing the long-range transport potential of polybrominated diphenyl ethers: a comparison of four multimedia models. Env. Tox. Chem., 2003, 22(6), 1252-1261.

Weiss J, Wallin E, Axmon A, Jönsson BA, Åkesson H, Janak K, Hagmar L and Bergman $\AA$. Hydroxy-PCBs, PBDEs and HBCDDs in human serum from an elderly population of Swedish Fishermen's wives and associations to bone density.

Environmental Science \&

Technology 2006; 40: (20): 62826289.

Weiss J, Meijer L, Sauer P, Linderholm $\mathrm{L}$, Athanasiadis I and Bergman Å.PBDE and HBCDD levels in blood from Dutch mothers and infants Analysis of a Dutch Groningen Infant Cohort. Organohalogen Compuonds, 2004, 2677-2682.

Xian Q, Ramu K, Isobe T, Sudaryanto A, Liu X, Gao Z, Takahasho S, Yu, H and Tanabe $\mathrm{S}$. Levels and body distribution of polybrominated diphenyl ethers (PBDEs) and hexabromocyclododecanes (HBCDs) in freshwater fishes from the Yangtze River, China. Chemosphere, 2007 (in press),

doi:10.1016/j.chemosphere.2007.09.0 32.

$\mathrm{Yu} \mathrm{CC}$ and Atallah YH.

Pharmacokinetics of HBCD in rats.
1980; pp 24. Vesichol Chemical Corporation. As cited in: European Commission, 2007a.

Zegers BN, Mets A, Van Bommel R, Minkenberg C, Hamers T, Kamstra JH, Pierce GJ and Bon JP. Levels of hexabromocyclododecane in harbor porpoises and common dolphins from Western European Seas, with evidence for stereoisomer-specific biotransformation by cytochrome P450. Environ Sci Technol 2005; 39: (7): 2095-2100

Zegers BN, Mets A, van Bommel R, Minkenberg C, Hamers T, Kamstra JH, Learmont JA, Vazquez BS, Pierce G, Reid B, Patterson T, Rogan E, Murphy S, Addink M, Hartmann MG, Smeenk C, Dabin W, Ridoux V, Gonzalez AF, López A, Jauniaux T and Boon JP.Stereo-isomer specific bioaccumulation of hexabromocyclododecane (HBCD) in marine mammals. In The third international workshop on brominated flame retardants - BFR 2004. Book of abstracts. Edited by Alaee M 2004; pp 411-414.

Zeller H and Kirsch P. Hexabromocyclododecane: 28-day feeding trials with rats. BASF (not published). 1969. As cited in: European Commission, 2007a.

Zeller $\mathrm{H}$ and Kirsch P. Hexabromocyclododecane: 90-day feeding trials with rats. BASF (not published). 1970. As cited in: European Commission, 2007a. 


\section{Sammanfattning}

I denna publikation görs en bedömning av informationen om egenskaperna hos ett bromerat flamskyddsmedel, hexabromcyclododekan (HBCDD) i förhållande till urvalskriterierna av Stockholmskonventionen om långlivade organiska föroreningar (POP) och UNECEs POP protokoll om långväga gränsöverskridande luftföroreningar för nya substanser. Publikationen ger också ytterligare information som behövs som bakgrund i övervägandet av om substansen skall nomineras som en ny POP i de två internationella avtalen.

Enligt den information som insamlats uppfyller HBCDD båda konventionernas urvalskriterier för nya substanser.

HBCDD uppfyller persistenskriteriet för POPs i luft. Det finns modelleringsresultat och miljöövervakninsdata från avlägsna trakter, som påvisar att HBCDD transporteras långväga i naturen.

Enligt simulerinsstudier uppfyller HBCDD POP-persistenskriteriet i jord. HBCDD är inte heller lätt nedbrytbar i aerobiska sediment, beroende på temperaturet. Miljöövervakningsdata bekräftar att HBCDD‘s nedbrytningstid i naturen kan vara längre än de tider som observerats i sedimentsimulerinsgstudier.

Biokoncentrationen av HBCDD i fisk har befunnits vara mycket hög och upfyller klart POP-kriteriet. Fältdata visar också att koncentrationen av HBCDD i vattenlevande organismer är högre på högre nivåer i näringskedjan. Flera studier av rovfåglar högst upp i näringskedjan ger ytterligare bevis för att HBCDD anrikas i näringskedjan och har hög persistens gentemot biologisk transformering.

HBCDD uppfyller POP-toxicitetskriterier på grund av att substancen är mycket giftig för akvatiska organismer . De olika effekterna som påvisats hos däggdjur i laboratorium ger ytterligare skäl till oro. De huvudsakliga effekterna hos däggdjur är störningar i levern och sköldkörteln. Andra effekter som har observerats är neurotoxiska utvecklingsstörningar och förändringar i könsorganen. Men för att kunna bedöma relevansen av de här effekterna är mera studier nödvändig.

Det finns även andra skäl till oro. HBCDD har uppmätts i synnerligen höga koncentrationer i späcket hos marina däggdjur i ett flertal regioner. Ökande koncentrationer i tidsserier av flera havsfågelpopulationen har observerats i Arktis. De flesta nyare mätningarna visar förhöjda koncentrationer av HBCDD i modermjölk och blod hos människa. HBCDD passerar enligt studier via placentan från moder in till ofödda barnet och in till födda barnet i modermjölk i amningstiden.

HBCDD används som flamskyddsmedel främst i polystyrenskum (EPS och XPS) som används som värmeisolationsskivor i t.ex. byggnader 
och fordon men också i hård polystyren för elektriska apparater och elektonik. Dessutom används HBCDD som flamskydd i textilier. Den globala efterfrågan på HBCDD var 16700 ton för 2001, varav största delen konsumerades i Europa.

Huvuddelen av de Europeiska utsläppen, som hat kunnat kvantifieras, sker från punktkällor. Men också diffusa kvällor kan vara relevanta. Volymen av HBCDD höjar sig konstant i den byggde miljön (produkter under använding). Miljöövervakningsresultat visar att avloppsvatten från kommunala reningsverk innehåller HBCDD även när inga kända industriella HBCDD användare är anslutna till avloppsnätet. Den Europeiska industrin har redan på frivillig väg börjat att minska de industriella punktutsläppen av HBCDD. Dessutom finns det alternativa kemikalier och tekniker som gör det möjligt att undvika användning av HBCDD för de flesta användningsområden. 


\section{Yhteenveto}

Tämä raportti on yhteenveto yhden bromatun palonestoaineen, markkinoilla olevan heksabromosyklododekaanin (HBCDD) keskeisimmistä ominaisuuksista suhteessa maailmanlaajuisen Tukholman yleissopimuksen ja YK:n alaisen Euroopan talouskomission (UNECE) kaukokulkeutuvien ilmansaasteiden rajoittamista koskevan sopimuksen POP pöytäkirjan uusien aineiden valintakriteereihin. Raportti sisältää myös lisätietoja, joita voidaan käyttää harkittaessa aineen mahdollista nimeämistä POP -sopimuksiin sisällytettäväksi yhdisteeksi.

HBCDD täyttää sekä Tukholman yleissopimuksen että UNECE:n kaukokulkeutumissopimuksen POP-pöytäkirjan uusille aineille asettamat ohjeelliset kriteerit.

HBCDD:n hajoamisaika ilmassa täyttää POP-kriteerit. Mallinnustulokset ja HBCDD:n pitoisuusmittaukset tausta-alueilta osoittavat, että HBCDD on kaukokulkeutuva.

Hajoamiskokeiden perusteella HBCDD täyttää POP-kriteerin aineiden pysyvyydestä maaperässä ja se on myös riittävän pysyvä sedimentin hapettuneessa kerroksessa lämpötilasta riippuen. Lisäksi pitoisuusmittaukset sedimenttinäytteistä osoittavat, että aineen todellinen hajoamisnopeus voi olla erilaisissa ympäristöissä pidempi kuin kokeissa nähdyt hajoamisnopeudet.

HBCDD on erittäin biokertyvä kaloihin laboratoriokokeiden perusteella ylittäen selvästi kertyvyyskriteerin POP-aineille. HBCDD:n pitoisuus on kenttämittausten perusteella korkeampi vesiympäristön ravintoverkon ylemmillä trofiatasoilla alempiin verrattuna, eli aine rikastuu ravintoverkossa. HBCDD:a on löytynyt useissa tutkimuksissa myös ravintoverkon huipulla olevista petolinnuista, mikä kertoo osaltaan HBCDD:n kyvystä vastustaa biologista hajoamista eliöissä ja kertyä ravintoverkossa.

HBCDD on erittäin myrkyllinen vesieliöille ja täyttää siten aineiden haitallisuudelle asetetut POP-kriteerit. Erityyppiset laboratorionisäkäskokeissa todetut haitalliset vaikutukset antavat lisäaihetta varovaisuuteen. Keskeisimmät vaikutukset nisäkkäissä ovat muutokset maksassa ja kilpirauhasessa sekä häiriöt kilpirauhashormonitoiminnassa. Laboratoriokokeissa on havaittu myös hermostollisia kehityshäiriöitä alhaisella kertaannostasolla sekä muutoksia sukupuolielimissä, mutta nähtyjen vaikutusten merkityksen selvittämiseksi tarvitaan lisää kokeita.

HBCDD:a on löydetty äidinmaidosta ja ihmisen verestä sekä laajalti erittäin korkeissa pitoisuuksissa merinisäkkäiden rasvasta. Aineen pitoisuuden on todettu nousevan ajan myötä eräissä merilintuyhdyskunnissa 
arktisella alueella. HBCDD siirtyy tutkimusten perusteella äidiltä lapselle kohdussa istukan kautta ja imetysiässä äidinmaidon mukana.

HBCDD:a käytetään pääosin paisutetussa ja suulakepuristetussa polystyreenivaahdossa, joita käytetään rakennusten ja ajoneuvojen eristelevyinä. Ainetta käytetään myös tekstiilien pintakäsittelymuoveissa sekä kovissa polystyreenimuoveissa sähkö- ja elektroniikkalaitteissa. Aineen maailmanlaajuinen kysyntä vuonna 2001 oli 16700 t, josta pääosa käytettiin Euroopassa.

Suurin osa niistä Euroopassa aiheutetuista päästöistä, joiden määrä on pystytty arvioimaan, päätyy ympäristöön pistekuormituksena. Siitä huolimatta hajakuormitus voi myös olla merkittävä ympäristön altistumisen aiheuttaja. HBCDD:n määrä sen loppukäyttökohteissa ihmisen rakentamassa ympäristössä on lisääntymässä. Hajapäästöjä aiheutuu teollisen tuotantoketjun alemmilta portailta, valmiiden tuotteiden käyttöajalta ja jätteenkäsittelyvaiheesta, mutta niiden suuruutta ei ole voitu arvioida tähän mennessä riittävän luotettavalla tasolla. Kunnallisissa jätevedenpuhdistamoissa tehtyjen mittausten perusteella HBCDD:a löytyy myös sellaisille puhdistamoille tulevista jätevesistä, joihin ei ole liittynyt ainetta käyttävää teollisuutta. Pistemäisten teollisuuspäästöjen vähentämiseksi on eurooppalainen teollisuus aloittanut vapaaehtoisen kampanjan. Hajalähteistä tulevien päästöjen vähentämiseksi on olemassa korvaavia aineita ja tekniikoita useimpiin HBCDD:n käyttötarkoituksiin. 


\section{Appendices}

\section{Appendix 1 Annex D of the Stockholm Convention}

\section{Information requirements and screening criteria}

1. A Party submitting a proposal to list a chemical in Annexes A, B and/or $\mathrm{C}$ shall identify the chemical in the manner described in subparagraph (a) and provide the information on the chemical, and its transformation products where relevant, relating to the screening criteria set out in subparagraphs (b) to (e):

(a) Chemical identity:

(i) Names, including trade name or names, commercial name or names and synonyms, Chemical Abstracts Service (CAS) Registry number, International Union of Pure and Applied Chemistry (IUPAC) name; and

(ii) Structure, including specification of isomers, where applicable, and the structure of the chemical class;

(b) Persistence:

(i) Evidence that the half-life of the chemical in water is greater than two months, or that its half-life in soil is greater than six months, or that its half-life in sediment is greater than six months; or

(ii) Evidence that the chemical is otherwise sufficiently persistent to justify its consideration within the scope of this Convention;

(c) Bio-accumulation:

(i) Evidence that the bio-concentration factor or bioaccumulation factor in aquatic species for the chemical is greater than 5,000 or, in the absence of such data, that the log Kow is greater than 5;

(ii) Evidence that a chemical presents other reasons for concern, such as high bio-accumulation in other species, high toxicity or ecotoxicity; or

(iii) Monitoring data in biota indicating that the bioaccumulation potential of the chemical is sufficient to justify its consideration within the scope of this Convention;

(d) Potential for long-range environmental transport:

(i) Measured levels of the chemical in locations distant from the sources of its release that are of potential concern;

(ii) Monitoring data showing that long-range environmental transport of the chemical, with the potential for transfer to a receiving environment, may have occurred via air, water or migratory species; or 
(iii) Environmental fate properties and/or model results that demonstrate that the chemical has a potential for longrange environmental transport through air, water or migratory species, with the potential for transfer to a receiving environment in locations distant from the sources of its release. For a chemical that migrates significantly through the air, its half-life in air should be greater than two days; and

(e) Adverse effects:

(i) Evidence of adverse effects to human health or to the environment that justifies consideration of the chemical within the scope of this Convention; or

(ii) Toxicity or ecotoxicity data that indicate the potential for damage to human health or to the environment.

2. The proposing Party shall provide a statement of the reasons for concern including, where possible, a comparison of toxicity or ecotoxicity data with detected or predicted levels of a chemical resulting or anticipated from its long-range environmental transport, and a short statement indicating the need for global control.

3 . The proposing Party shall, to the extent possible and taking into account its capabilities, provide additional information to support the review of the proposal referred to in paragraph 6 of Article 8. In developing such a proposal, a Party may draw on technical expertise from any source. 
Appendix 2 Executive body decision 1998/2 on information to be submitted and the procedure for adding substances to Annexes II or III to the POPs Protocol (EB.AIR/WG.5/52, ANNEX II)

The Executive Body,

Resolved to act as early as possible to develop criteria and procedures for adding substances to the forthcoming protocol on persistent organic pollutants,

Adopts, with reference to article 14, paragraph 6, of the protocol, the requirements for information to be submitted and the procedure for adding substances to annexes I, II or III to the protocol on persistent organic pollutants set out below.

Information to be submitted and the procedure for adding substances to annexes i, ii or iii to the protocol on persistent organic pollutants

1. A Party submitting a proposal to amend annexes I, II or III in accordance with article 14, paragraph 6, shall provide the Executive Body with a risk profile on the substance and information on the characteristics below, following the guidance and indicative numerical values, which demonstrate:

(a) Potential for long-range transboundary atmospheric transport: evidence that the substance has a vapour pressure below 1,000 $\mathrm{Pa}$ and an atmospheric half-life greater than two days. Alternatively, monitoring data showing that the substance is found in remote regions; and

(b) Toxicity: potential to adversely affect human health and/or the environment;

and

(c) Persistence: evidence that the substance $=\mathrm{s}$ half-life in water is greater than two months, or that its half-life in soils is greater than six months, or that its half-life in sediments is greater than six months. Alternatively, evidence that the substance is otherwise sufficiently persistent to be of concern within the scope of the protocol; and

(d) Bio-accumulation:

(i) Evidence that the $\mathrm{BCF}$ or $\mathrm{BAF}$ for the substance is greater than 5,000 or the log Kow is greater than 5; or

(ii) Alternatively, if the bio-accumulative potential is significantly lower than (i) above, other factors, such as the high toxicity of the substance, that make it of concern within the scope of the protocol. 
The proposal shall also contain a summary report and include, as available, information on:

(i) Production/uses/emissions, measured environmental levels in areas distant from sources, abiotic and biotic degradation processes and rates, degradation products, bioavailability; and

(ii) Socio-economic factors related to the alternatives and/or the techniques available to reduce the emissions of the proposed substance including:

- Alternatives to the existing uses and their efficacy;

- Any known adverse environmental or human health effects associated with the alternatives;

- Process changes, control technologies, operating practices and other pollution prevention techniques which can be used to reduce the emissions of the substance, and their applicability and effectiveness; and

- The non-monetary costs and benefits as well as the quantifiable costs and benefits associated with the use of these alternatives and/or techniques.

2. Upon receipt of a submission prepared in accordance with paragraph 1 above and if the risk profile is deemed acceptable, the Parties shall, at a meeting of the Executive Body and by consensus, ensure that one or more technical reviews of the proposal are conducted if, on the basis of the submission and any other relevant information submitted to the Executive Body, further consideration of the substance is determined to be warranted. Any such technical reviews shall be in writing and evaluate, inter alia:

(a) The monitoring or equivalent scientific information suggesting long-range transboundary atmospheric transport; and

(b) Whether sufficient information exists to suggest that the substance is likely to have significant adverse human health and/or environmental effects as a result of its long-range transboundary atmospheric transport; and

(c) A list of the sources of the substance in the atmosphere, including the use of products, estimates of the total emissions from these sources and the methodologies used; and

(d) Whether measures exist to reduce the risk of adverse effects on human health and/or the environment as a result of its long-range transboundary atmospheric transport, and whether they are technically feasible, as well as their associated effects and costs.

3. The term risk profile mentioned in paragraphs 1 and 2 above refers to a comprehensive review of the scientific information related to the determination of general human health and environmental risks associated with the uses and releases of a substance. Such a review need not explic- 
itly address risks associated with long-range transboundary air pollution, but must provide suitable information for the assessment of such risk.

4. On the basis of the submission specified in paragraph 1 above and any technical review(s) that may have been prepared in accordance with paragraph 2 above, the Parties shall, at a meeting of the Executive Body, complete their evaluation of the proposal taking into account the objective of the protocol set out in article 2 .

\section{Appendix 3 Properties of 1,5,9-cyclododecatriene (CAS 4904-61-4)}

The data on following properties of cyclododecatriene (CDT) has been mainly extracted from the publicly available IUCLID (European Commission, 2000).

\begin{tabular}{|c|c|c|}
\hline & & Reference \\
\hline \multicolumn{3}{|l|}{ Structural formula } \\
\hline Molecular formula & $\mathrm{C} 12 \mathrm{H} 18$ & \\
\hline Molecular weight & 162.3 & \\
\hline \multirow{2}{*}{\multicolumn{3}{|c|}{ Kpa }} \\
\hline & & \\
\hline Melting / freezing point & $-15^{\circ} \mathrm{C}$ & EpiSuite $\mathbf{v} .12$ \\
\hline Boiling point & $237^{\circ} \mathrm{C}($ at $\left.1013 \mathrm{hPa})\right)$ & EpiSuite $\mathrm{v} 3.12$ \\
\hline Vapour pressure & $0.12 \mathrm{hPa}$ (at $20^{\circ} \mathrm{C}$ ) & European Commission (2000) \\
\hline \multirow[t]{2}{*}{ Water solubility } & $5 \mathrm{mg} \mathrm{l}^{-1}\left(\right.$ at $\left.20^{\circ} \mathrm{C}\right)$ & (European Commission (2000) \\
\hline & $0.34 \mathrm{mgl}^{-1}$ (at $\left.25^{\circ} \mathrm{C}\right)$ & WSKOW v 1.41 \\
\hline Partition coefficient n- & 5.1 & European Commission (2000) \\
\hline octanol/water (log value) & 5.5 & KOWWIN v1.67 \\
\hline \multirow[t]{2}{*}{ BCF (Cyprinus carpio) } & $2630-12500$ (10 $\mu \mathrm{g} / \mathrm{l}$ test conc.) & MITI (1992) \\
\hline & $1920-14800(1 \mu \mathrm{g} / \mathrm{l}$ test conc. $)$ & \\
\hline
\end{tabular}

Overview of the key data on persistence

Biodegradation of cyclododecatriene (CDT) has been studied in four tests of which two provide reliable, well documented results. $t, t, t 1,5,9-$ cyclododecatriene was studied by Davis et al. (2006a) in a ready biodegradability test according to OECD $301 \mathrm{~F}$ at test concentrations of 1 and $10 \mathrm{mg} / \mathrm{l}$. Dispersion of CDT into the test medium was aided by coating it onto silica gel (mixing on a roller bank for $72 \mathrm{~h}$; loadings of 1 and $10 \mathrm{mg}$ $\mathrm{CDT} / \mathrm{g}$ silica gel used). The incubation with $30 \mathrm{mg} / \mathrm{l}$ inoculum of activated sludge from Midland municipal waste water treatment plant, Michigan, U.S. followed at $20^{\circ} \mathrm{C}$ for 60 days. Triplicate reaction mixtures were analysed for CDT with GC-UV at frequent intervals. A parallel set of 
vials were used to analyse $\mathrm{CO}_{2}$-evolution. $\mathrm{CDT}$ started to disappear at both test concentrations after a lag phase of at least 14 days. No significant $\mathrm{CO}_{2}$-production compared to controls occurred during the test. In addition, abiotic degradation did not take place according to autoclaved sterile controls. CDT disappeared completely in average by day 77 at both test concentrations. At $10 \mathrm{mg} / 1$ test level CDT disappeared slightly more slowly than at the lower test concentration. This may have been caused by a slight inhibition (aniline+CDT used for inhibition control). The results indicate, that CDT is not readily biodegradable although it is subject to primary degradation.

In an experiment of Davis (2006b) using similar experimental conditions as avis et al (2006a) but with test concentrations of $0.2 \mathrm{mg} / \mathrm{l}$ and 1 $\mathrm{mg} / \mathrm{l},{ }^{14} \mathrm{C}$-labelled CDT disappeareance was monitored by HPLC and ultimate degradation was followed by means of ${ }^{14} \mathrm{CO}_{2}$-analysis. Duplicate test vials were sampled at frequent intervals. After 63 (77) days of incubation, the ${ }^{14} \mathrm{CO}_{2}$ formation reached ca. 50 (70) \% at 0.2 (1) $\mathrm{mg} / \mathrm{l}$ test concentration, respectively. A phase of slow mineralisation until ca. 35 days (44.5\% CDT remaining; $11 \%$ of CDT mineralised at $0.2 \mathrm{mg} / 1$ level) was observed. During the study, a transient degradation product with a shorter elution time than CDT was detected by HPLC-analysis. The peak size of this (unidentified) product increased during the first month followed by a decrease towards the end of the study. Based on the test, CDT is considered as not readily biodegradable, but due to the extent of ultimate degradation achieved, it can be expected to be degradable.

This limited set of data on biodegradation of CDT indicates, that the substance can be mineralised in enhanced ready biodegradation test conditions.

\section{References}

Davis JW, Gonsior SJ and Hales CA. The aerobic biodegradability of trans, trans, trans-1, 5, 9-Cyclododecatriene in a modified ready biodegradation test. 2006a; pp pp 62.

Davis JW. The aerobic biodegradability of trans, trans, trans-1, 5, 9-

$[14 \mathrm{C}]$ Cyclododecatriene in a modified ready biodegradation test. $2006 \mathrm{~b}$.

EpiSuite v 3.12. U.S.EPA, 2000.

European Commission. IUCLID Dataset, cyclododeca-1,5,9-triene, CAS 4904-61-4. Feb $18,2000$.

KOWWIN v1.67. In: Episuite v 3.12, U.S.EPA, 2000.

MITI. Biodegradation and Bioaccumulation data of Existing Chemicals based on CSCL Japan, Compiled under the Supervision of Chemical Products Safety Division, Basic Industries Bureau MITI, ed. by CITI, 1992. Published by Japan Chemical Industry

Ecology-Toxicology \& Information Center.

WSKOW v 1.41. In: Episuite v 3.12, U.S.EPA, 2000. 


\section{Appendix 4 The results of the EU risk assessment, quantitative risk characterisation for the environmental part (European Commission, 2007a)}

In the following table those sources are listed, which were concluded to cause risks ("conclusion iii"). For other scenarios (excluding secondary poisoning route) no quantitative risks were identified.

\begin{tabular}{|c|c|}
\hline Receiving compartment & The source causing risks \\
\hline \multirow[t]{10}{*}{ Freshwater } & Some of the known sites involved in EPS formulation \\
\hline & Generic site involved in EPS formulation *) \\
\hline & One site involved in XPS formulation \\
\hline & Generic site involved in XPS formulation *) \\
\hline & Generic site for formulation of polymer dispersions for textiles*) \\
\hline & Two sites involved in industrial use of XPS \\
\hline & Generic site involved in industrial use of XPS compound \\
\hline & Three sites involved in industrial use of HBCDD powder for flame retarded XPS \\
\hline & Some of the known sites involved in textile backcoating \\
\hline & Generic site involved in textile backcoating \\
\hline \multirow[t]{11}{*}{ Freshwater sediment } & Some of the known sites involved in EPS formulation \\
\hline & Generic site involved in EPS formulation \\
\hline & One site involved in XPS formulation \\
\hline & Generic site involved in XPS formulation \\
\hline & One site involved in formulation of polymer dispersions for textiles \\
\hline & Generic site involved in formulation of polymer dispersions for textiles \\
\hline & Some of the known sites involved in industrial use of XPS \\
\hline & Generic site for industrial use of XPS compound \\
\hline & Two sites involved in industrial use of HBCDD powder for flamer retarded XPS \\
\hline & Some of the known sites involved in textile backcoating \\
\hline & Generic site involved in textile backcoating \\
\hline \multirow[t]{10}{*}{ Marine water } & Some of the known sites involved in EPS formulation \\
\hline & Generic site involved in EPS formulation \\
\hline & One site involved in XPS formulation \\
\hline & Generic site for XPS formulation \\
\hline & One site involved in formulation of polymer dispersions for textiles \\
\hline & Generic site involved in formulation of polymer dispersions for textiles \\
\hline & Some of the known sites involved in industrial use of XPS \\
\hline & Generic site for industrial use of XPS compound \\
\hline & Some of the known sites involved in textile backcoating \\
\hline & Generic site involved in textile backcoating \\
\hline \multirow[t]{11}{*}{ Marine sediment } & Some of the known sites involved in EPS formulation \\
\hline & Generic site involved in EPS formulation \\
\hline & One site involved in XPS formulation \\
\hline & Generic site involved in XPS formulation \\
\hline & One site involved in formulation of polymer dispersions for textiles \\
\hline & Generic site involved in formulation of polymer dispersions for textiles \\
\hline & Some of the known sites involved in industrial use of XPS \\
\hline & Generic site involved in industrial use of XPS \\
\hline & Some of the known sites involved in textile backcoating \\
\hline & Generic site involved in textile backcoating \\
\hline & $\begin{array}{l}\text { In addition, measurements in marine sediment associated to a producer of EPS } \\
\text { beads (EPS formulation) gives a RCR }>1 \text {, which indicates that there are con- } \\
\text { cerns for this site and that there may be a general concern for this use area }\end{array}$ \\
\hline \multirow{3}{*}{$\begin{array}{l}\text { Terrestrial compartment (organ- } \\
\text { isms directly exposed via soil) }\end{array}$} & Generic site for industrial use of XPS compound \\
\hline & Three sites using HBCDD powder in the production of XPS \\
\hline & $\begin{array}{l}\text { One site involved in textile backcoating. Generic site involved in textile back- } \\
\text { coating }\end{array}$ \\
\hline \multirow[t]{3}{*}{ Waste water treatment plant } & $\begin{array}{l}\text { Some of the known sites with industrial use of XPS having intermittent releases } \\
\text { to waste water }\end{array}$ \\
\hline & One textile backcoating site \\
\hline & Generic site involved in textile backcoating \\
\hline
\end{tabular}

*) Generic site represents the (known and unknown) sites which did not provide any site specific data to refine the exposure estimation. 